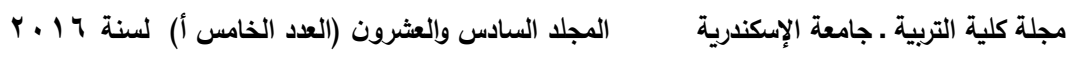

\title{
موجهات الترخيص لفروع جامعات عابرة للحدود في المملكة العربية السعودية على ضوء التحديات العالمية والمحلية
}

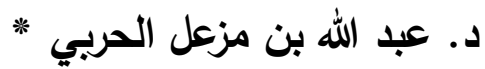

\section{المقدمة}

يعد تدويل التعليم العالي من الاتجاهات التعليمية المستحدثة، فقد

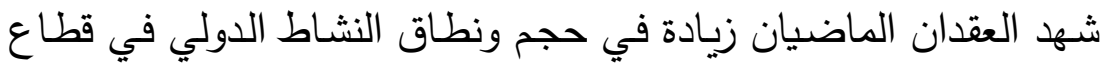
التعليم العالي في جميع أنحاء العالم لم يسبق لها مثيل استجابة لعوامل

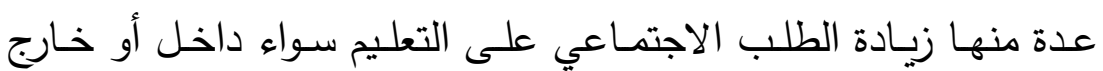
الدولة، وسوق العمل المعولم، واحتياجات اقتصـاد المعرفة، والرغبة في

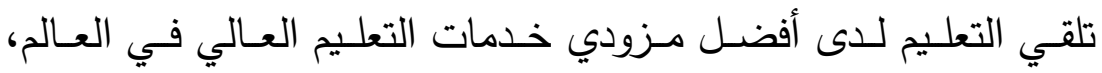
وانخفــاض تكـاليف التتقـل، والتطـــورات فــي تكنولوجيــا المعلومـــات

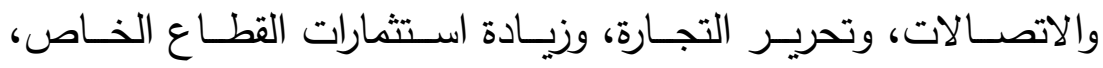
.(Ennew \& Fujia,2009)

كل هذا فرض ضرورة وجود أشكال جديدة للتعليم العالي في عالم يتحرك نحو عولمة السوق وتأهيل خريجين قادرين على التتافس للحصول على فرص عمل جديدة في سياق دولي، لذا ظهرت عديد من المشروعات

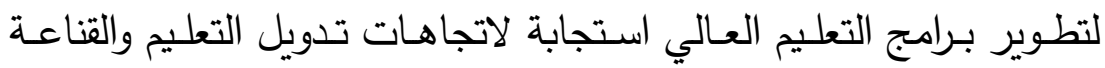

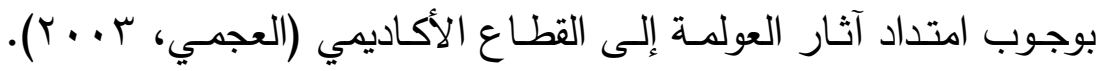

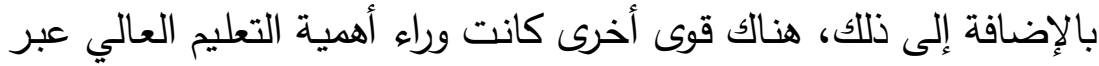
الحدود تمثلت في زيادة وعي الدول بالدور الذي يمكن أن يقوم به التعليم

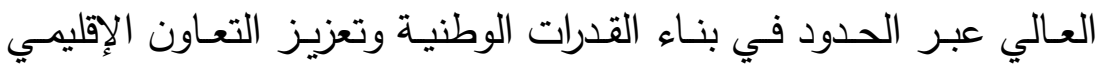
والعالمي. 
وفي ظل الاتفاقيـة العامـة للتجـارة الدوليـة في الخدمات (الجـات)

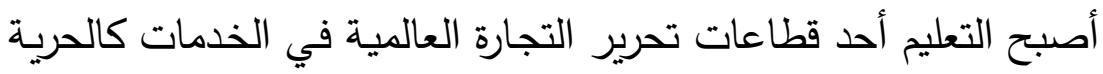
المتمثلة في الوصول إلى أسواق التعليم أو أنظمته عبر الحدود بواسطة

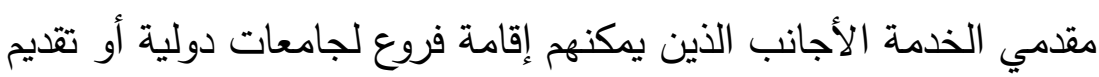
برامج دراسية عن بعد أو عقد اتفاقيات تبادل أكاديمي بين الجامعات.

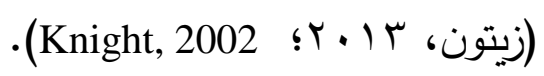

وبطبيعة الحال، فقد بدأت بعض الدول في اتخاذ خطوات جديدة

لتدويل التعليم العالي إلى جانب مقدمي التعليم العالي التقليدي، كإقامة

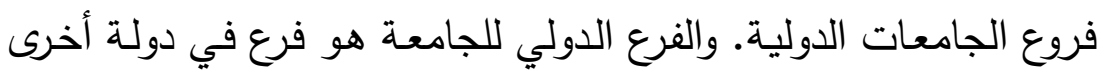
غير دولة المقر الأم للجامعة، حيث يتلقى الطلاب التعليم وجهاً لوجه في بلد آخر ، ويعمل فرع الجامعة تحت نفس اسم المؤسسة الأم، والمؤهلات (Wilkins,

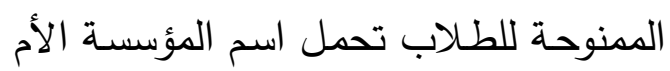
(2010. وقد بـدأ هذا الاتجـاه في جامعـات أمريكـا وبريطانيا وأستراليا بإقامة فروع لها في الخارج؛ ولنجاح التجربه سرعان ما امتد هذا الاتجاه لبعض دول العالم الأخرى.

كمـا سـعت بعض الدول الناميـة لاجتذاب جامعـات مـن الدول

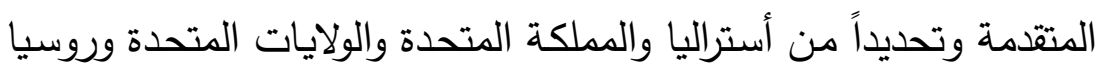
وفرنسا وذلك لما تتميز به جامعات تلك البلدان من سمعة أكاديمية عالية

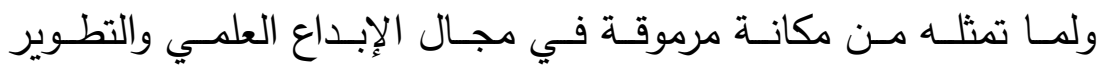

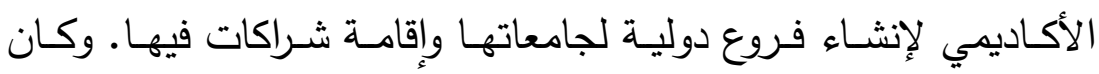

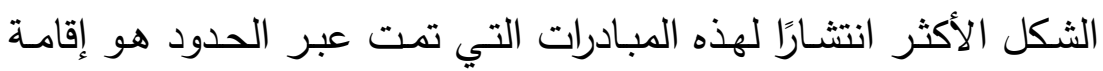
فروع دولية للحرم الجامعي.

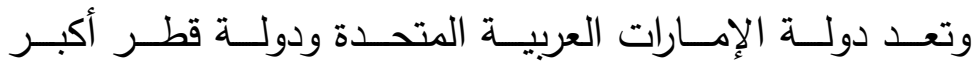

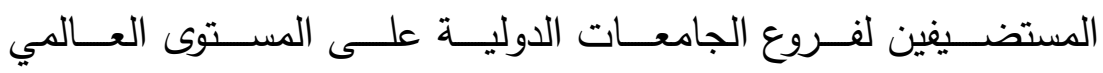
(Wilkins, 2011). وفي المملكة العربية السعودية توجد أنماط من التعليم 
العالي العابر للحدود، حيث توجد اتفاقيات تعاون وتآخي بين العديد من

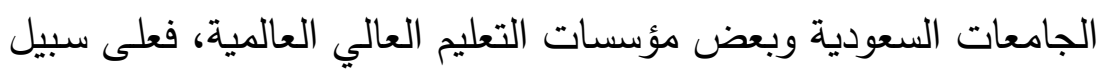

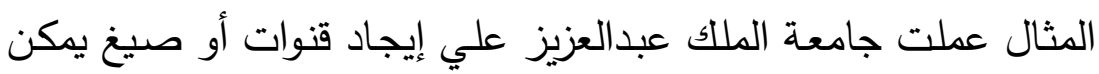
من خلالها إتاحة الفرص المناسبة لبعض المعيدات والمحاضرات اللاتي لا تتـوفر لهـن الظـروف الاجتماعيـة للابتعـاث خـارج المملكـة، ولـديهن الرغبـة الجـادة في الحصـول على درجـة الدكتوراه مـن جامعـات دوليـة

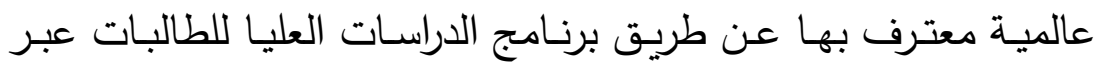

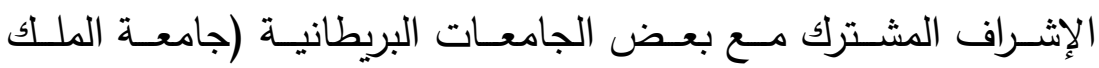

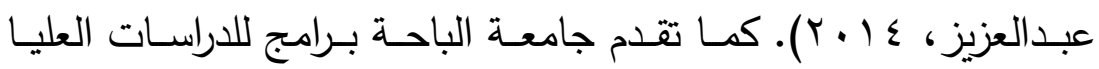
بالتعاون مع جامعات عالمية مرموقة مثل جامعة أوهايو ، وجامعة فلوريدا أتلانتيك في الولايات المتحدة الأمريكية وجامعة أبسالا في السويد (جامعة

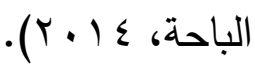

وهذا الأمر لا ينحصر في التعليم العالي داخل المملكة فحسب، بل

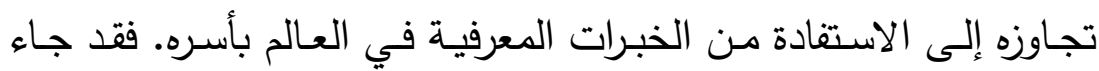

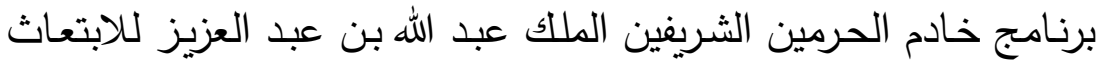

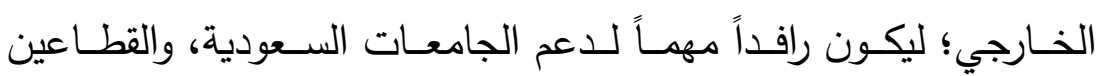

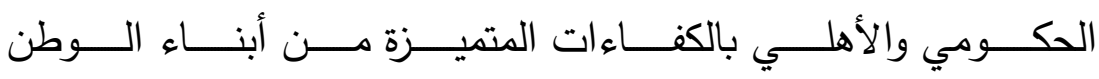

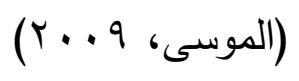

إلا أنه وحتى وقتنا هذا لا توجد فروع لجامعات عابرة للحدود في المملكة العربية السعودية على الرغم من تقديم جامعات كثيرة طلبات لفتح فروع لها في المملكة؛ إضـافة إلى تقدم العديد مـن الثـركات بطلبات لإنشاء جامعات أجنبية لأبناء رعايا الدول الأجنبية في المملكة العربية

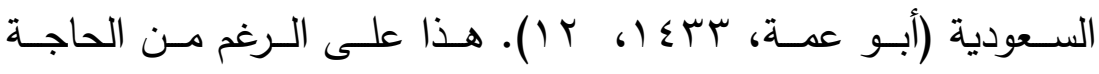
الواضحة لدعم التعليم العالي الوطني بتجارب عالمية في مجال التعليم

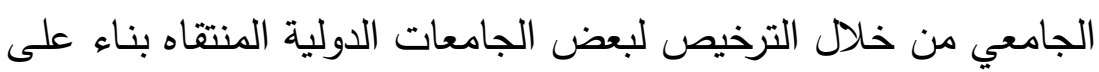


مـا تتمتع بـه مـن سمعة عالميـة في مجـالات البحث العلمي والتطـور التكنولوجي، والتدريس وإعداد للقوى البشرية اللازمة لتحمل أعباء التتمية من جهة، ودفع عمليات التطوير المستدام للتعليم الجامعي السعودي من ون

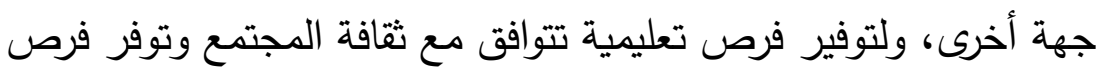
تعليمية لفئات نوعية منه مثل الإناث.

ومن هنـا يتضـح أن هنالك فجوة بين واقع الممارسـة التعليميـة في

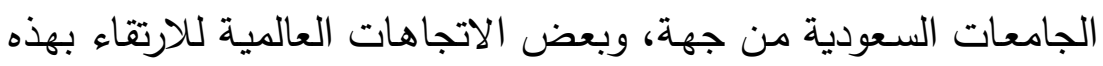

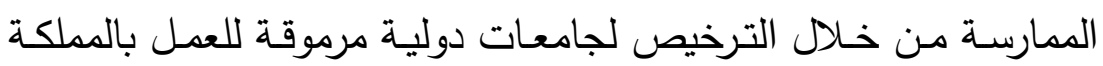
العربية السعودية ضمن معايير وفلسفة وقيم الثقافة السعودية من جهة دهرة

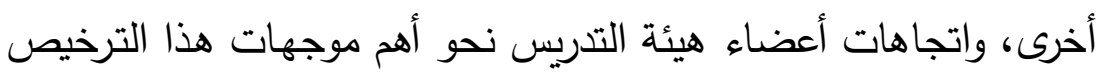

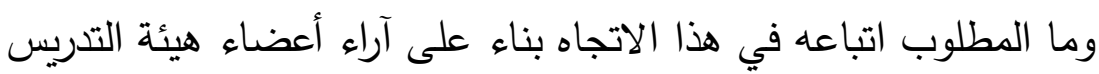

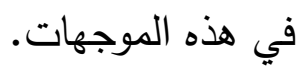
مشكلة الدراسة فئة الموجة

أطلقت المملكة العربية السعودية شعار "وراء كل أمسة عظيمة تربية عظيمـة" لمواجهة التحديات الكبرى التي تواجهها في جميع المجـالات. ولكي يتسنى للمملكة تطبيق هذا الشعار قولاً وعمـلاً، فإن هناك جهداً

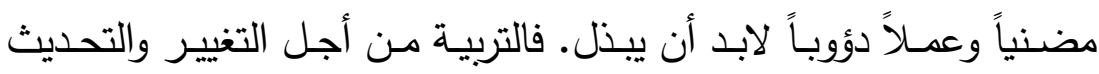
تستلزم بداهـة تطوير نظام تربوي جديد قادر على تكوين الإنسان الجديد القادر على الإبداع والمنافسة والتميز والإنتاج في ضدوي هوئ معيات المنافسة

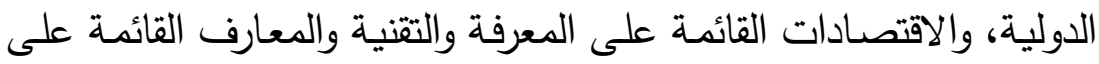
قان اني الخ داع الإنس ع، والإبـ

$$
\text { (السنبل، }
$$

ولقد زاد الاهتمام بقطاع التعليم العالي في السنوات الاخيرة بسبب إسهامه في تحسين الإنتاجية، وزيادة النمو الاقتصادي، وتعزيز الابتكار 


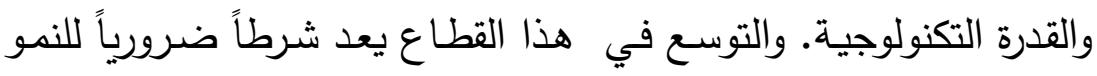
والتوسع في الاقتصاد العالمي (Tilak, 2011).

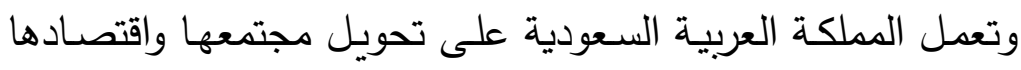
الذي يعتهـد على النفط وعلى الغـاز إلى مجتمـع قـائم على المعرفـة. فالهدف هو تتشئة مواطنيها ليكونوا مسؤولين عن هذا المجتمع القائم على الى المعرفة. ويبدو هذا هذا الجهد أكثر وضوحاً من خلال الخطوات الكبيرة

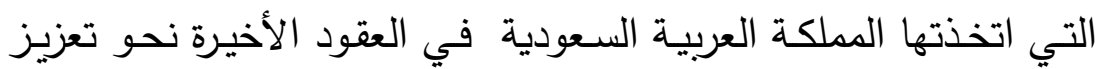
قدراتها في مجال التعليم والبحوث. وعلى الرغم من ذللك فمـا زال التعليم العالي السعودي يعاني من بعض التحديات التي تواجهه كالعولمة وظهور اقتصاد المعرفة والطلب الكبير على المهارات والتطورات التقنية ومواجهة المنافسـة القادمـة من لن

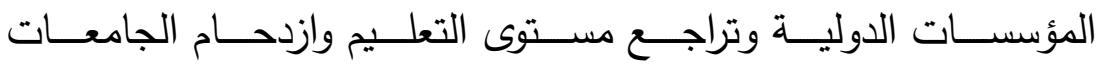

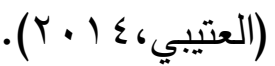
أمسا عـن أسباب عدم مواءمــة مخرجـات التعليم العـالي السـودي لمتطلبات سوق العمل فتتمثل في زيادة أعداد الملتحقين بالتعليم العالي موني وعدم كفاءة الإرشـاد الأكاديمي في توجيـه المقبولين للتخصصـات التي يحتاجها سوق العمل وعدم تطوير المناهج التعليمية وعدم توفر الخبرة العملية لخريجي الجامعـة وعدم إجادة خريجـي الجامعة للغـة الإنجليزيـة

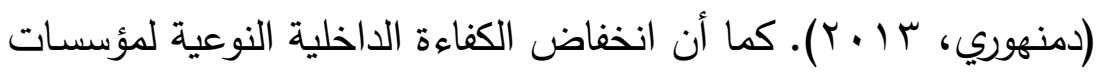

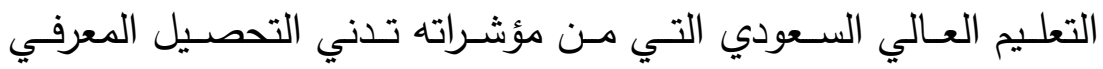

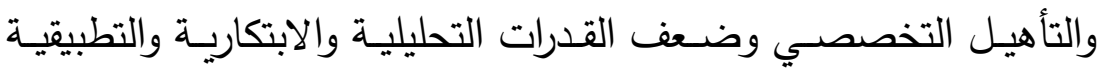
والقصـور في تعزيـز القيم والاتجاهـات الانتاجيـة ، وانخفـاض الكفـاءة

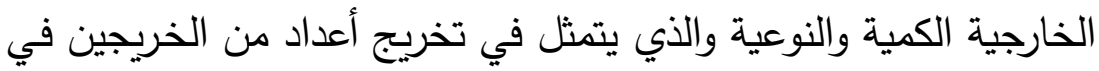

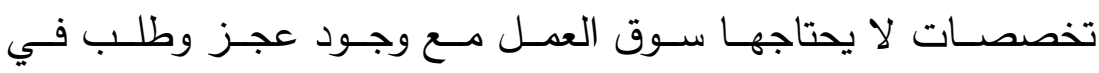

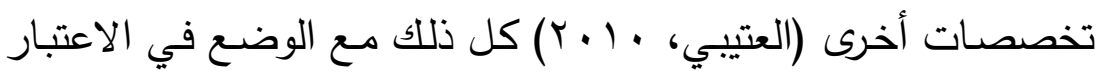




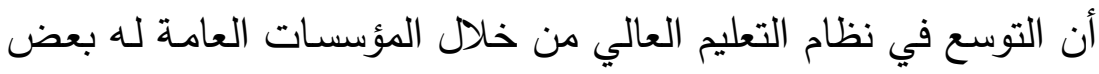

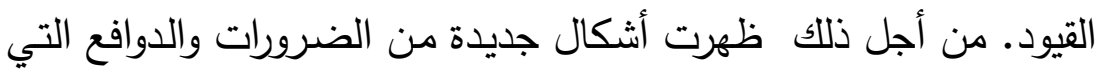

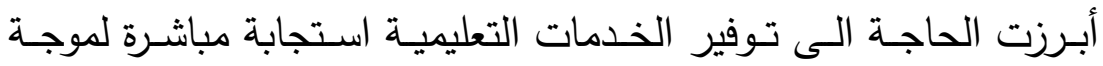

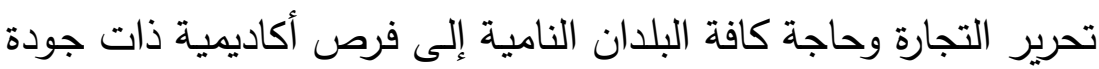
وكفاءة عالية. فالخيار المطروح توسيع التعليم العالي من خلاد الاعتماد على موارد التمويل الخاص ومنها تشجيع مقدمي خدمات التعليم العالي العابر للحدود (Varghese, 2011).

لذلك فإن فكرة الترخيص لفروع جامعات عابرة للحدود في المملكة العربية السعودية تمثل استجابة للتحديات العالمية والمحلية التى يواجهها

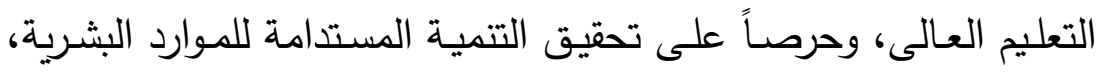

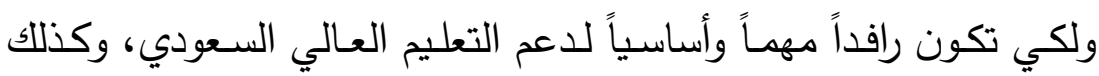
مساندة القطاعين: الحكومى والأهلى في مجال التعليم العالي، و لذلك الكي تحاول الدراسة إجابة الأسئلة الآتية:

1- مـا أهم التحديات العالميـة والمحلية التي لهاليها انعكاسـات مباشـرة

على منظومة التعليم العالي في المملكة العربية السعودية؟

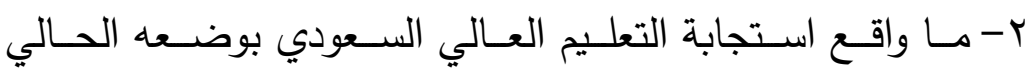
للتحديات العالمية والمحلية؟ وابه r- مـا المقصـود بـالتعليم العـالي العـابر للحدود ومـا طبيعتهـ وأهم خصائصه؟ ع - مـا الموجهات الأساسية الدافعة نحو الترخيص لفروع جامعات عابرة للحدود في المملكة العربية السعودية؟

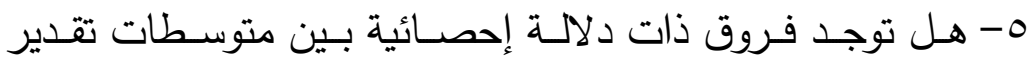

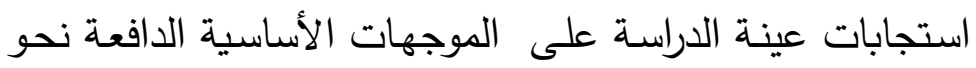
التـرخيص لفـروع جامعـات عـابرة للحدود في المملكــة العربيـة 


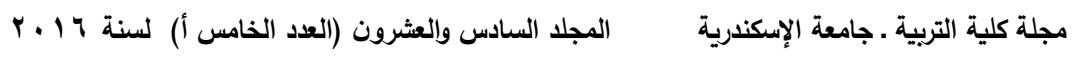

السعودية تعزى لمتغيرات: النوع، التخصص، الجنسية، الرتبة

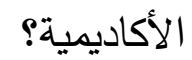

7- مـا إيجابيات وسلبيات الترخيص لفروع جامعات عـابرة للحدود

بالمملكة العربية السعودية على ضوء رؤى التغييرات المستقبلية

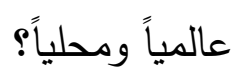

أهداف الاراسة

\section{تحاول الدراسة تحقيق ما يلي:}

- رصد أهم التحديات العالمية والمحلية التي لها انعكاسـات مباشرة

على منظومة التعليم العالي في المملكة العربية السعودية.

- رصد استجابة التعليم العالي السعودي بوضعها الحالي للتحديات

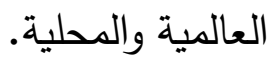

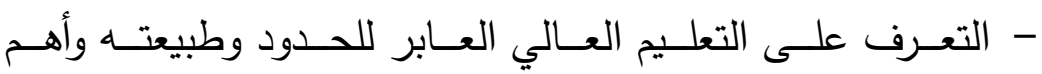

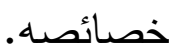

- تحديد الموجهات الأساسية الدافعة نحو الترخيص لفروع جامعات عابرة للحدود في المملكة العربية السعودية.

- الكثـف عـن فروق ذات دلالـة إحصـائية بين متوسطات تقدئه

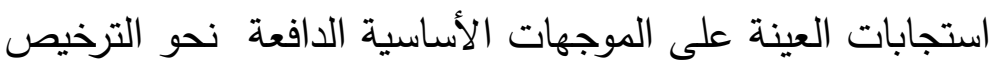

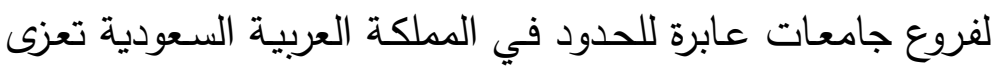
لمتغيرات الدراسة: النوع، التخصص، الجنسية، الرتبة الأكاديمية.

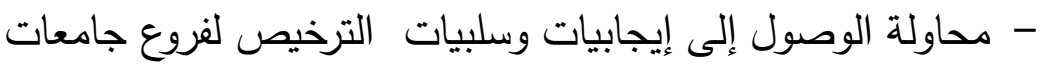

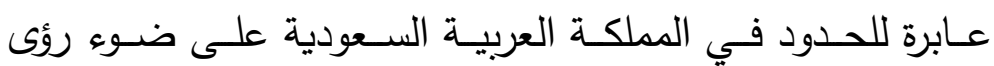
التغييرات المستقبلية عالمياً ومحلياً. 


\section{تتضح أهمية الاراسة من خلال ما يلي:}

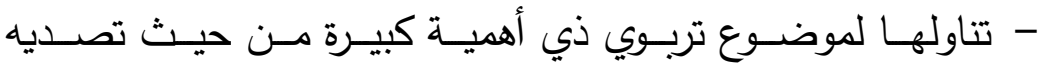

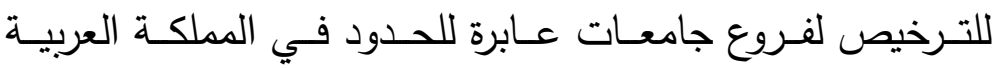

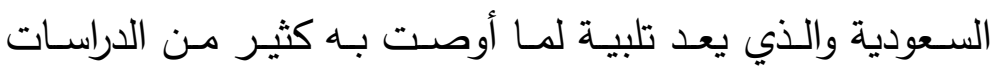

السـابقة والندوات والمؤتمرات بضـرورة إجراء دراسـات عن تدويل

التعليم العـالي وضـرورة إيجاد صيغ جديدة للتوسـع في خدمات

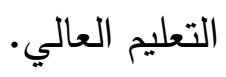

- تعد الدراسة الأولى في المملكة العربية السعودية - على حد علم الباحث - التي تتنـاول الموجهات الدافعـة نحو الترخيص لفروع

جامعات عابرة للحدود في المملكة العربية السعودية - قد تفيد صانعي السياسة التعليمية ومتخذي القرار في مجال التعليم

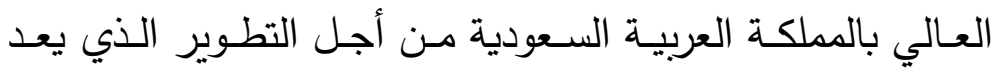
مطلباً ضرورياً في ضوه التحولات المتسارعة. محددات الدراسة معرا يمكن عرضها على النحو التالي: المحدد الموضوعي:

تقتصـر الدراســة على الموجهـات الدافعـة نحــ التـرخيص لفـروع جامعات عابرة للحدود في المملكة العربية السعودية.

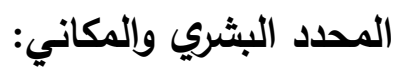
تقتصر الدراسـة على استطلاع رأي أعضـاء هيئة التدريس بجامعـة فئس الدمام في المنطقة الثرقية.

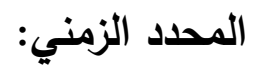

تم تطبيق الدراســة الميدانيـة في الفصـل الدراسـي الأول مـن العـام

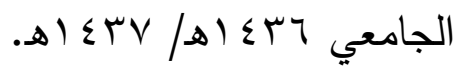
مصطات الاراسة 
الموجهات Guidelines : هي عوامل موجودة في البيئة المحيطة

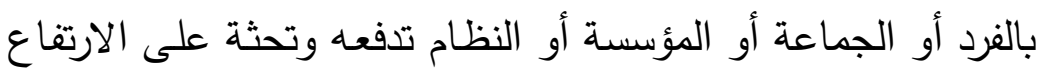

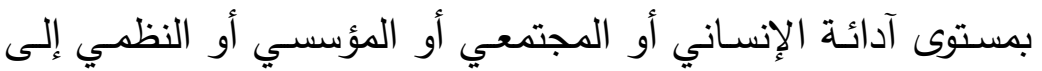

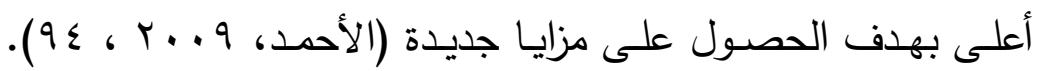
وتعرف أيضاً بأنها محفزات الإسراع في القيام بالشيء (السروري، $.(0) \leqslant 6 . .9$

ويمكن تعريفها إجرائياً في هذه الدراسـة بأنها : تلك الضرورات والدواعي العالمية والمحلية (اجتماعية - اقتصادية - تربوية - سياسية) الأكثر أهمية والدافعة نحو الترخيص لفروع جامعات عابرة للحدود في ولئي لتربيه المملكة العربية السعودية .

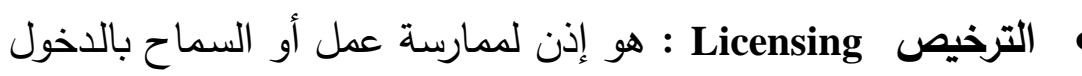

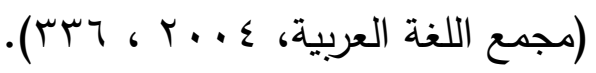

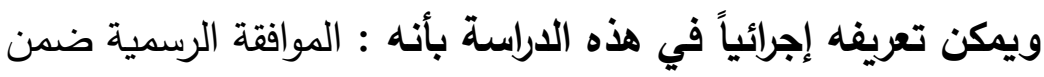

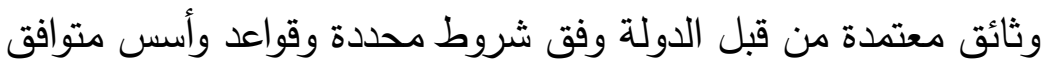
عليها بين طرفين لممارسة العمل من قبل مقدم الخدمة لصالح مانح وثيقة الترخيص ولفترة زمنية محددة.

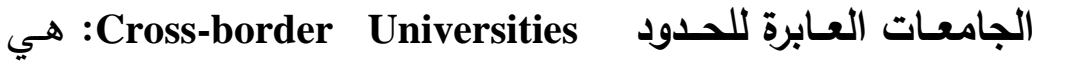
مؤسسة تعليمية تقدم خدمات التعليم العالي في دولة أخرى من خلال

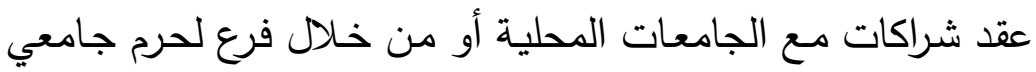

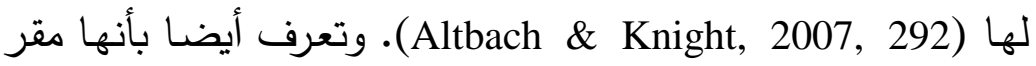

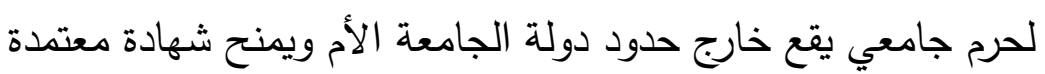

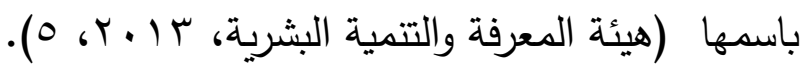

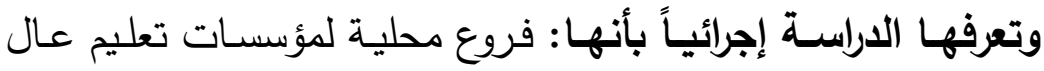

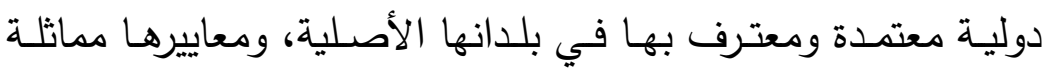


لمعايير الجامعات الأصلية، وتحمل نفس الاسم، وتصدر شهاداتها

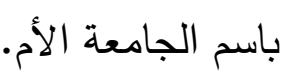

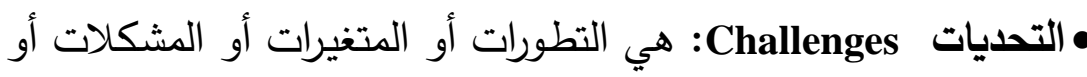

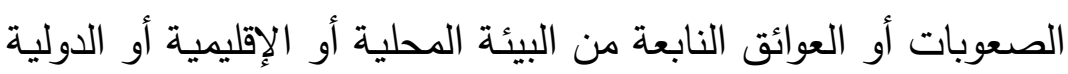

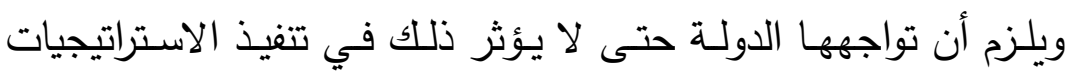

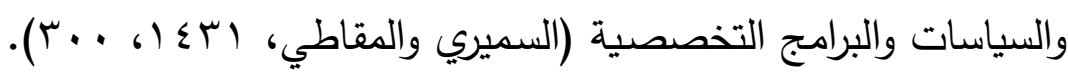

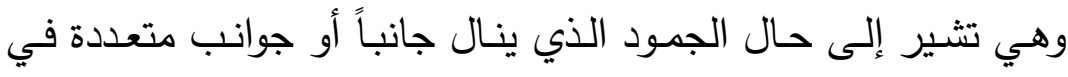
النظام التربوي يفقده نوعاً من التوازن، وتؤدي إلى خلل في مقدرته على التى

$$
\text { آداء وظيفته.(وطفه، ب99 19 1، ^). }
$$

وتعرفها الدراسة إجرائياً بأنها: مجموعة الإشكالات الآنية والمستقبلية

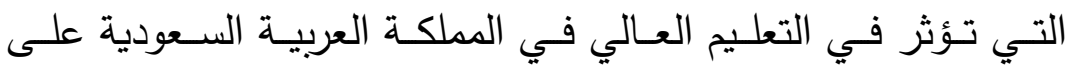
المستويين الخارجي والداخلي وتتطلب المواجهة. منهج الدراسة

باعتبـار هذه الدراسـة مـن دراسـات الرأي، ومـن الدراسـات التي تحاول توصيف الواقع للانطلاق إلى وضع خطوط عريضة لصانع القرار

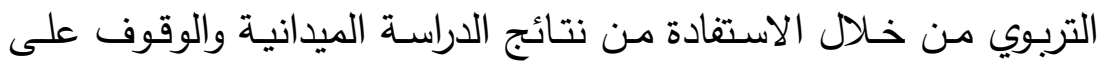
الايجابيات والسلبيات المحتملة لهذا النوع من التعليم في المملكة العربية

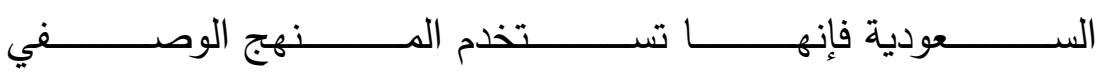
(Anderson \& Arsenault , 2000, 100) الرأي طبقت على أعضـاء هيئة التدريس بجامعـة الدمام في المملكة

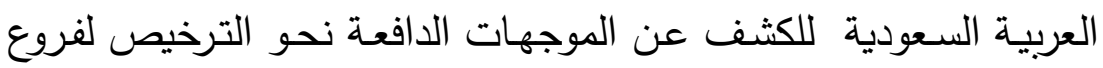
جامعات عابرة للحدود في المملكة العربية السعودية. 
أولاً: التعديات التي تواجه التعليم العالي في المملكة العربية السعودية: لقد شكلت التحديات عقبات في تطوير حركة التعليم في الدول

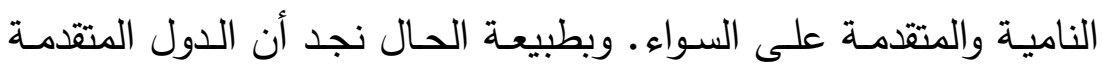

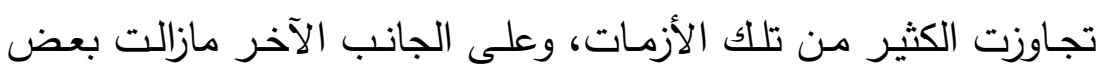

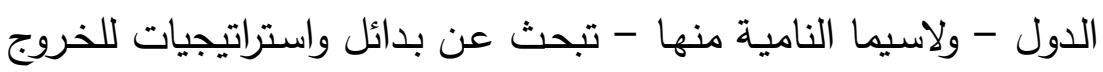
من تلك الأزمات والتغلب على تلك التحديات. والمملكة العربية السعودية بلد لله خصوصيته الاجتماعية والثقافية ولها من الجذور الحضارية والدينية وما يحيط بها من عوامل ومتغيرات تنعكس بالضرورة على مختلف مؤسسـات التعليم وبخاصـة بنية التعليم العالي، وهذه التحديات وغيرها تتطلب تضافر الجهود للتصدي لها لإزالة الخلل، والتحدي الذي تثير إليه الدراسة يظهر في جانبين: الأول داخلي،

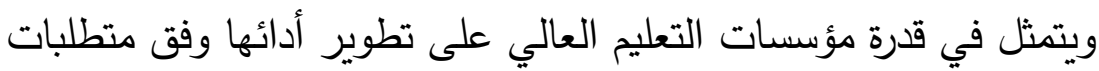

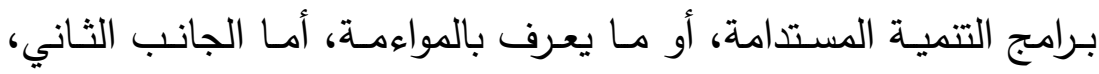
فيتمثل في التحديات الخارجيـة والتي تتــوع بـين التوجهات التعليميـة المعاصرة والتغيرات في إدارة التعليم العالي، ونتائج اللقاءات والمؤتمرات التين التي تنظمها المؤسسات والمنظمات، أو تحد من نموه، ومن فعاليته، وفي ضوء ذللك يمكن طرح بعض من التحديات الداخلية والخارجية التي تواجه التعليم العالي من جهة وحركة التتمية من جهة أخرى والجهود المبذولة للحد من تلك التحديات، وذلك على النحو الآتي: 
إن طرح التحديات الخارجية إنما ينطلق من جدل قائم يدور حول

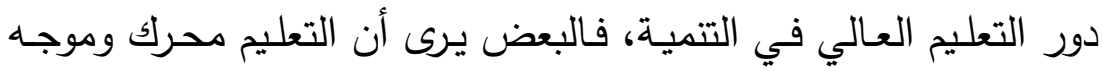

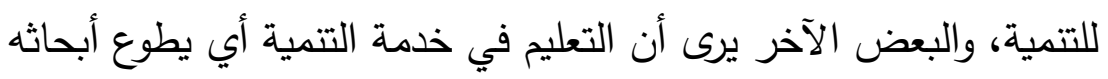

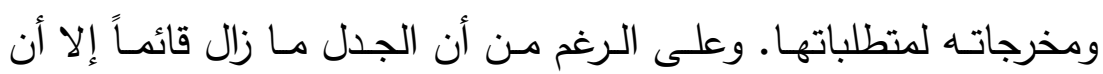
هناك من الشواهد والدلالات ما يؤكد أن التعليم ذو أبعاد تفاعلية، كونه أنه

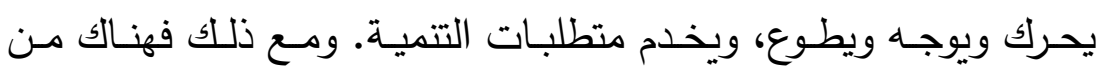

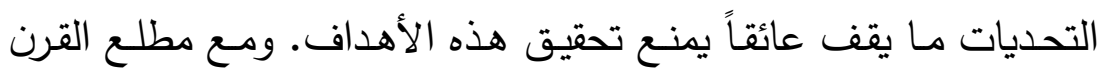

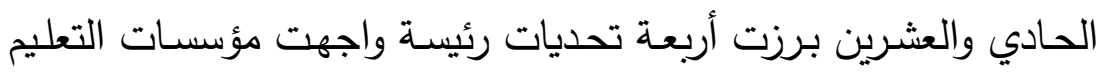
العالي هي: - 20 - 20

\section{العولمة الاقتصادية}

منذ أن امتد أثر العولمة لكل الدول، وكان من أثرها المباشر على التى منظومـات التعليم ظهور بعض الإشكاليات، مثل الفجوة بين المهارات

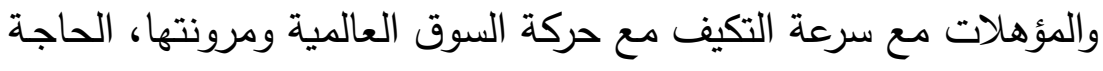
إلى التقويم (الجودة) والاعتماد، مشكلات لغة التعليم وتحدياتها، تسارع

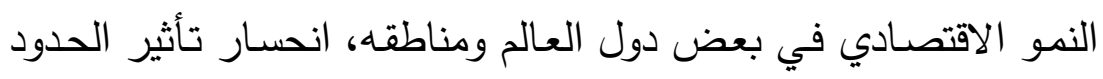

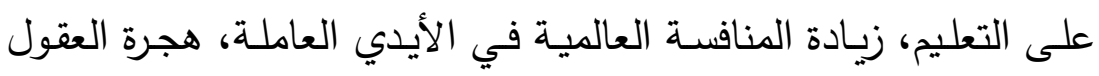

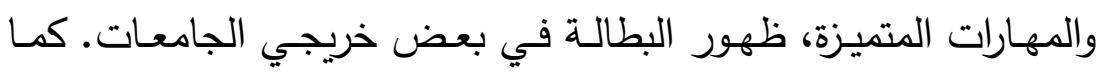

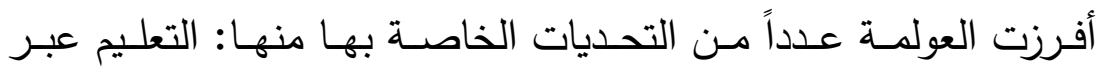
الحدود، التعلم الإكتروني والتعليم عن بعد، التقويم والاعتماد الأكاديمي،

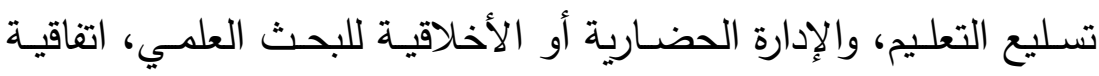

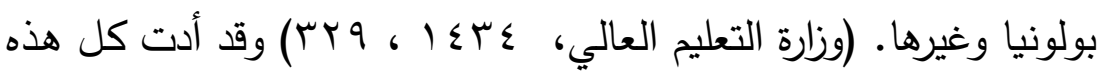

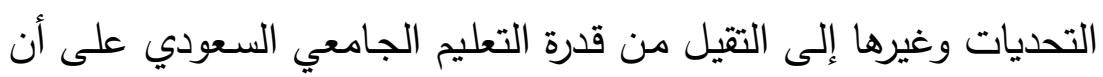

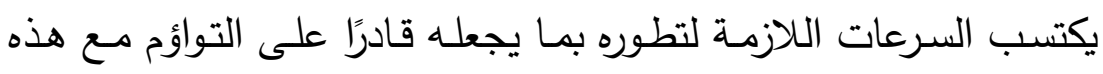

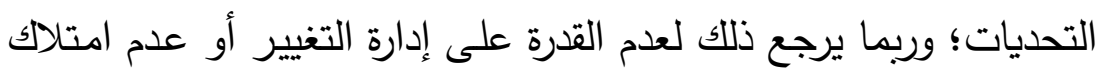
إرادته أو كليهما معًا. 


\section{• بزوغ مجتمع المعرفة واقتصادياته}

يعـد اسـتخدام تقنيـات المعرفـة فـي العمليـة التعليميـة مـن أبـرز

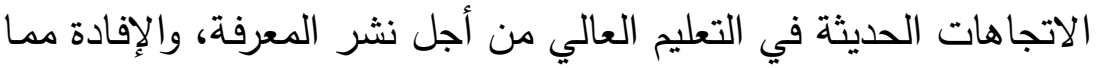
تتنجه التقنيات في تفعيل دور التعليم وزيـادة الإنتاجية العلمية. لذا فقد فئد توجهت العديد من الدول نحو اقتصـاد المعرفة، والذي يعتمد على إنتاج

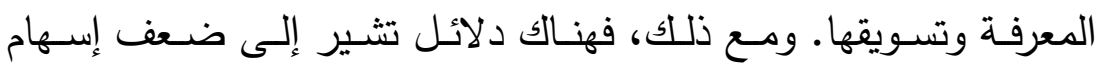

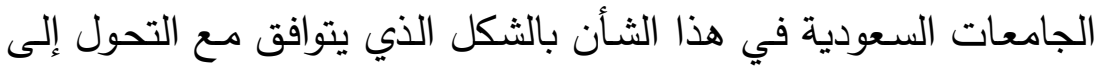

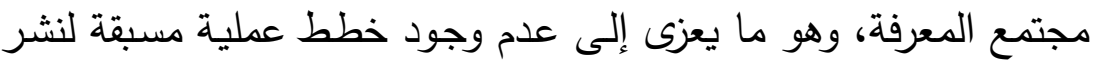

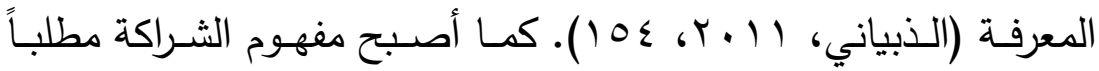
أساسياً بين الجامعـات والثـركات والمؤسسـات. ولهذه الأهميـة المتزايدة

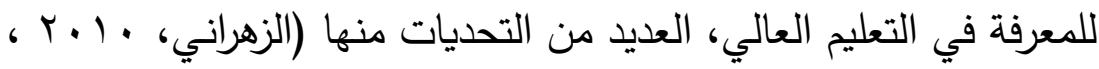

$$
:(r V \cdot-r T \Lambda
$$

الدور التقليدي لبعض الجامعات ومؤسسات التعليم العالي من حيث الاستقلالية المطلقة وعدم التجاوب مع التغيرات المجتمعية.

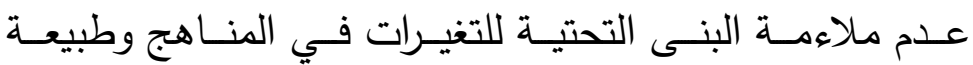

$$
\text { المهارات والتخصصات. }
$$

طبيعة أعضاء هيئة التدريس من حيث التأهيل والوظائف الدائمة

$$
\text { التي تحد من التحول السريع. }
$$

وقد انعكس كل ذلك - بصـورة مباشـرة - على الكفايـة الداخليـة

والخارجية للتعليم الجامعي مما قد يؤدي إلى ارتفع مستوى الهـر الكمي

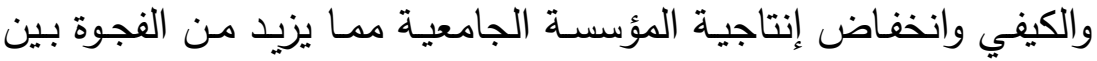
تعليم الداخل ومـا يحدث في الخارج من تطورات بل قفزات في تطوير التعليم الجامعي. 
لعل مـا أفرزته ثورة المعلومـات من أنمـاط جامعيـة جديدة مثل

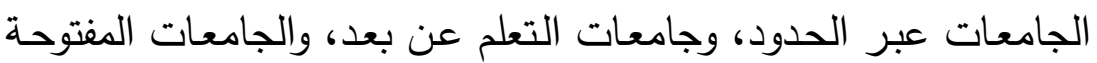

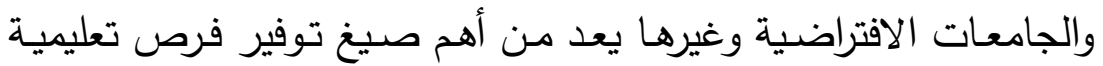
وفق متطلبات وحاجات المتعلمين. إلا أن الشواهد تشير إلى أن استخدام

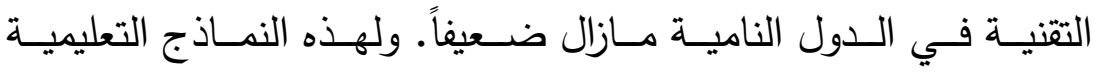
والجامعات التقنية أثر في بروز العديد من التحديات في الكثير من دول

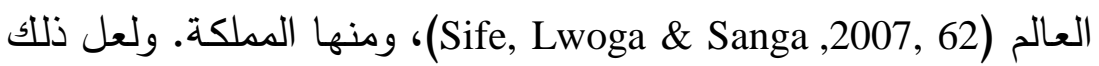
يمكن أن يكون لـه علاقة ببعض القضـايا منها تداخل القيم والثقافات، والتفاعل مع المجتمع الدولي، والتحفظات حول التعليم المستورد، وتأهيل

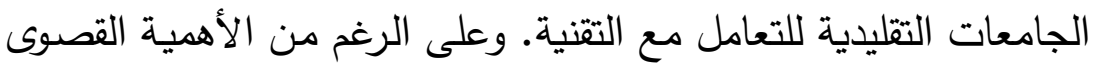
للثورة المعلوماتية في تأثيرها المباشر على منظومة التعليم الجامعي بكل مكوناتها وكذلك تأثرها بها، فإن أخطر ما في هذا الموضوع التهر هو ما وفرته

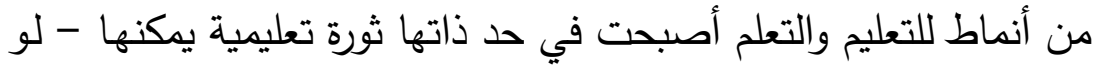
أُحسن توظيفها - أن تحقق استدامة التعلم وتحقيق مبدأ ديمقراطية التعليم

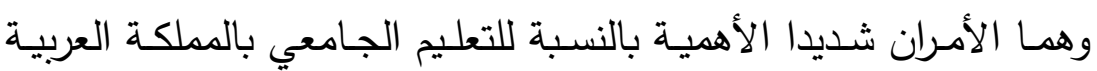
السعودية.

\section{• تدويل التعليم الجامعي}

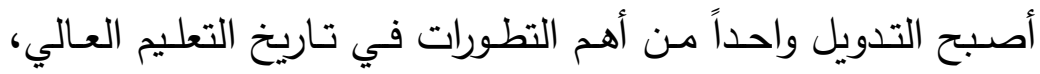
حيث ظهرت العديـد مـن بـرامج التعـاون الـولي إلى جانب الاهتمـام

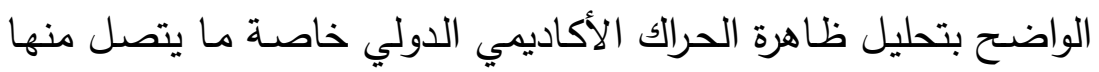

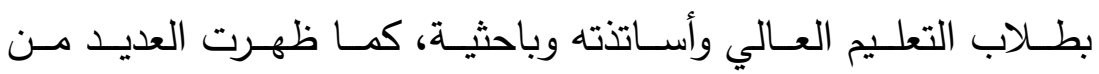
مشـروعات تطـوير بـرامج التعلـيم العـالي اسـتجابه لاتجاهـات التـدويل

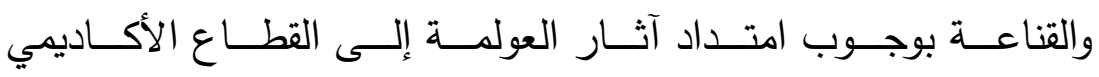
.(Qiang, 2003, 248) 
وفي الفترة الأخيرة بدأت الكثير من دول العالم في اتخاذ خطوات

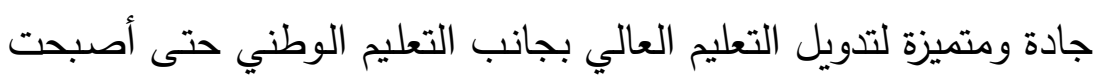

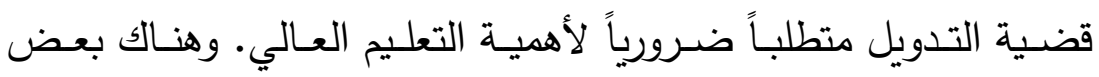
التحديات التي تواجه التدويل منها (Merey\& Alkan, 2015, 1-2):

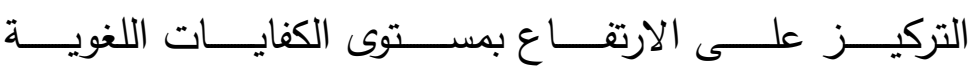
(اللغة الانجليزيـة) لدى كل من الطلاب وأعضاء هيئة التدريس بالجامعات. توفيركافة الكفايات والمهارات المهنية اللازمة للتغيير في المهن وفق متطلبات سوق العمل عالمياً.

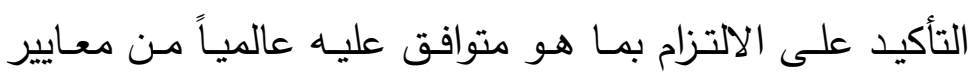
التمويـل والتخطـيط، والتخطـيط الإقليمسي والـدولي والمعـايير الأكاديمية وكذللك متطلبات منح الثهادات على المستوى الدولي.

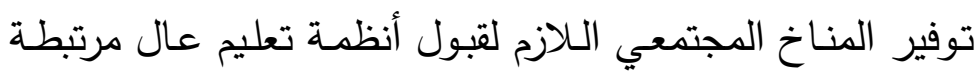
بالجامعات ذات السمعة الأكاديمية الدولية.

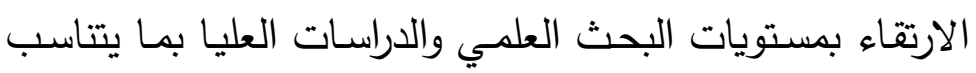
مع معايير النشر الدولية والالتزام بأخلاقيات البحث العلمي.

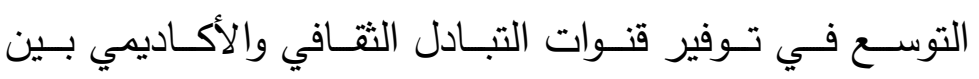
الجامعات السعودية والأجنبية بما يسمح بأعلى درجة من الحرات العلمي والتعليمي.

إن قدرة المجتمع السعودي على التغلب على هذه التحديات لاشك التك

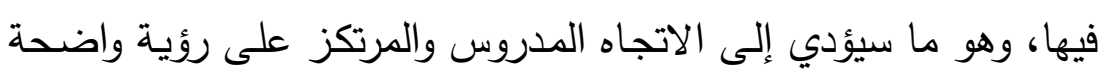

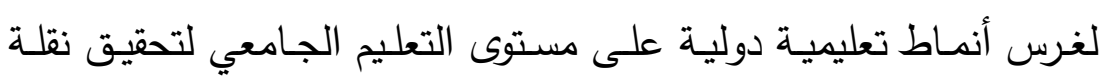

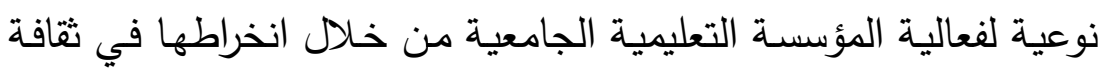

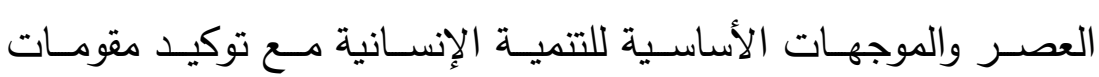
الخصوصية الثقافية ودعم الانتماء. 


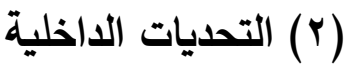

هناك بعض المعوقات التي لابد وأن تؤخذ في الحسبان ويتم التعامل معها بأسلوب علمي ورؤية واضحة والتي منها:

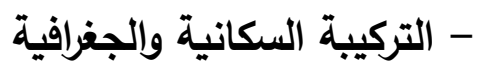

تُعد المملكة العربية السعودية من أكثر الدول نمواً سكانياً حيث والجغرايه

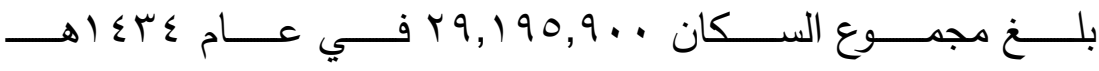

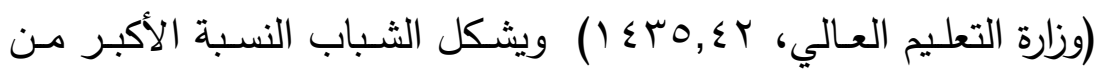

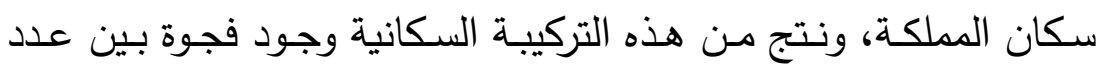
خريجي المرحلة الثانوية من جهة والمقاعد المتاحة في مؤسسات التعليم من جهة أخرى، إذ تضاعف عدد خريجي المرحلة الثانوية في الفترات

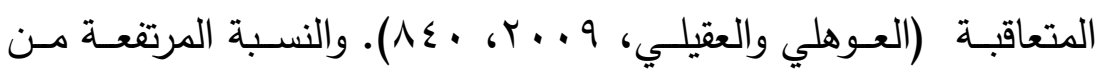

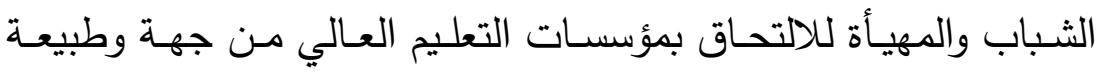
التوزيـع الجغرافي الواسـع للتجمعـات السكانية على مسـاحة تشـبه القـارة

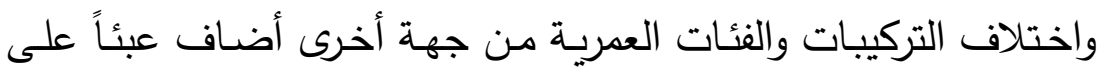

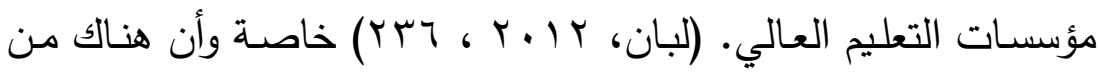
العوامل الأخرى ما يرتبط بذلك مثل: •تحجيم القبول في التخصصـات النظريـة سيترتب عليه عدم تمكن

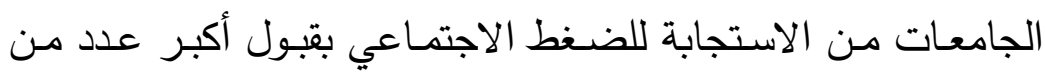
خريجي التعليم العام ممـا يترتب عليـه إثكاليات اجتماعيـة وغيرهـا.

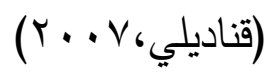

•محدودية استيعاب الكليات العملية والتطبيقية للطلاب نتيجة طبيعة تخصصاتها، وما تستلزمه من مختبرات ومعامل وأجهزة ومستشفيات مع ارتفاع تكلفة إنشاء الكليات وبخاصـة التطبيقية والعملية وصعوبة توفير الإمكانيات البشرية والمادية اللازمـة لبدء العمل بهذه الكليات

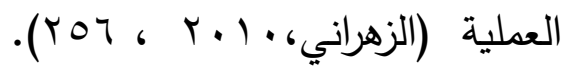


• زيادة الطلب على التعليم العالي التي تعاني منها مؤسساته ستكون

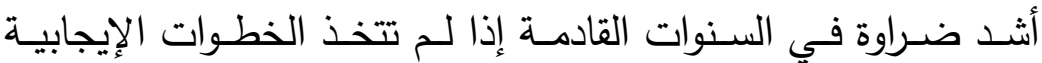
لامتصاص تلك الأعداد الكبيرة، وتوفير الخدمات التعليمية المناسبة رق الط

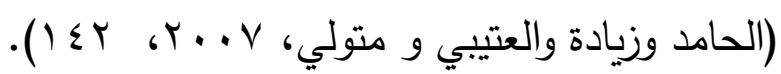

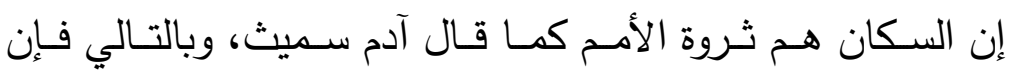

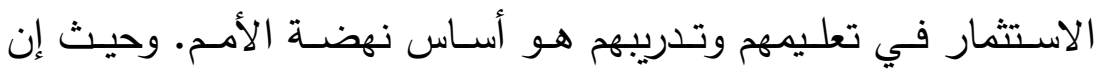

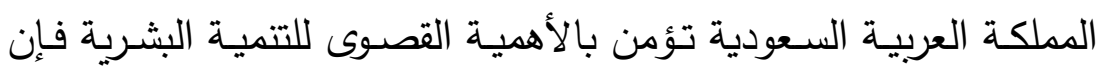
الزيادة السكانية غير المسبوقة يمكن أن تشكل تهديدًا للمجتمع إذا لم يتم

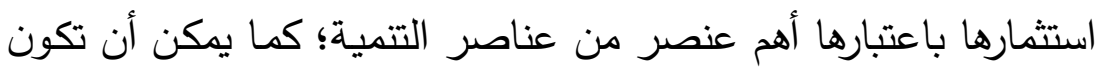
أثثن الفرص إذا تم توفير التعليم الجامعي اللازم لإعداد مواطنين منتجين منتمين، وهو ما تسعى الدولة إلى تحقيقه.

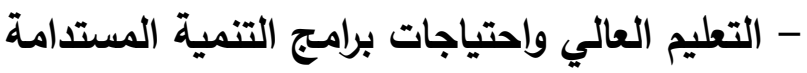

تسعى مؤسسات التعليم العالي في الكثير من الدول إلى تلبية احتياجات برامج التتمية وتوفير الكفاءات البشرية التي تحتاجها الدول،

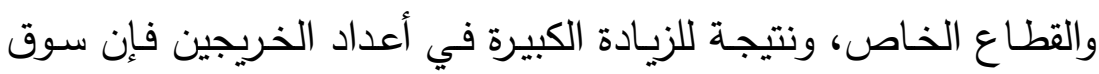

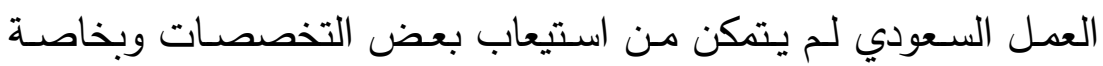

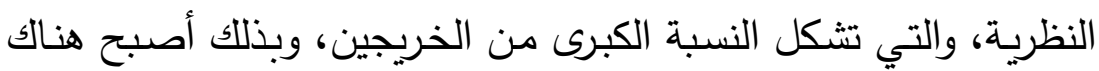
فائض في تلك التخصصات، وفي بعض الأحيان تتوجه أصابع الإتهام

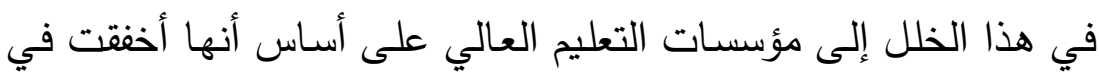

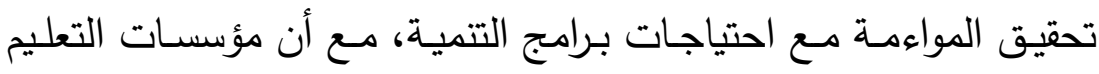

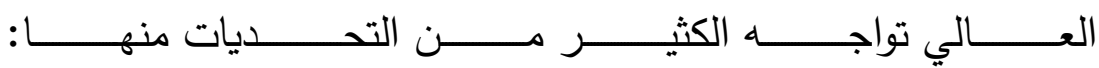

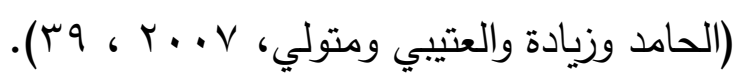

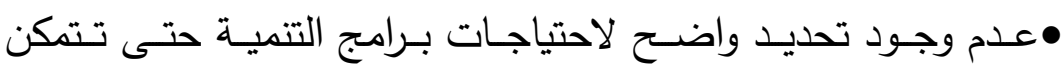
مؤسسات التعليم العالي من التخطيط السليم المتدرج لتلبيتها، حيث لـيث 
أن التغيير في التعليم العالي بطيء نسبياً، هذا بالإضـافة إلى عدم

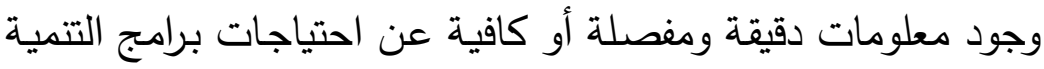
المستدامة، مـع رغبة بعض مؤسسات القطاع الخاص في توظيف

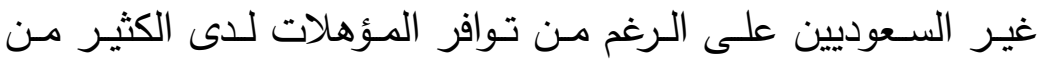
الخريجين السعوديين.

•برامج التنمية المستدامة تتطلب تنوعاً في مؤسسـات التعليم العالي

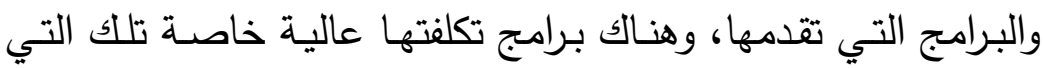

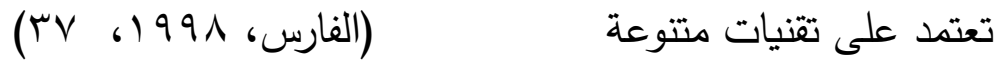
•اعتمـاد الاقتصـاد السعودي على النفط مما يجعل الاقتصـاد عرضـة لتغيرات وتحولات متعددة تبعاً للظروف المحلية والإقليمية والدولية.

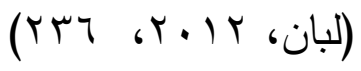

•هذا بالإضافة إلى وجود عدد من العوامل التي تسهم في عدم توافق مخرجات الجامعات مـع متطلبات برامج التتمية المستدامة أهمها، عدم إثراك قطاع العمل في تحديد سياسـة القبول، علاوة على عدم تطـوير المنــاهج حسـب احتياجـات المتغيـرات العالميــة والمحليـة، بالإضـافة إلى عـدم تعـاون جهات تخطيط القوى العاملـة بالثـكل

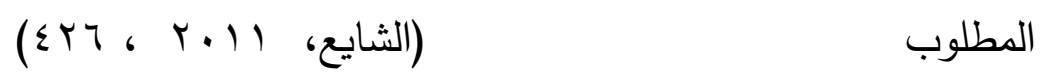
كل مـا سبق يفرض ضـرورة الإسـراع في تتفيذ البرامج الضـرورية

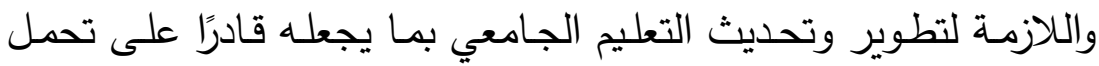
أعباء التنمية المستدامة من خلال الانفتاح على تجارب وصيخ ودئ دولية في لفي مجال التعليم الجامعي تحقق قفزة التطوير المرغوب ضمن بيئة سعودية تعزز هويتها وتحافظ على خصوصيتها.

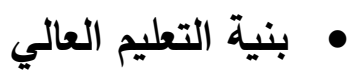

المسـتقرئ، والمحلـل لبنيـة التعلـيم العـالي في المملكـة العربيـة

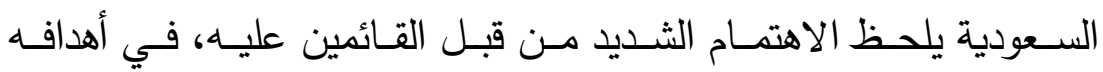


ومدخلاته، وعملياته، ومخرجاته، إيماناً منهم بأن التعليم العالي في المملكة

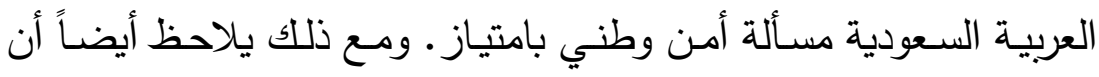

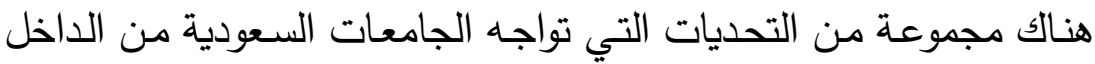
منها :

•يتمثل التحدي الذي تواجهه الجامعات السعودية في تفعيل مؤسسات

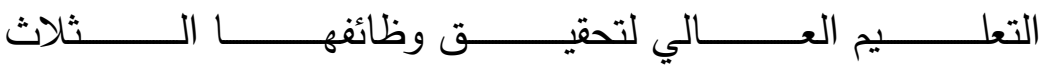
(التـدريس/ البحـث العلمـي/ خدمــة المجتهـع). إذ يسـتلزم المجتمـع

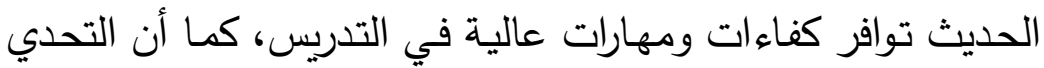
القادم يتمثل في توجيه البحوث العلمية لما ينفع المجتمع، ويزيد من كفاءة قطاعاته المختلفة، وحل مشكلاته المتعددة، كما يتمثل تحدي لهي

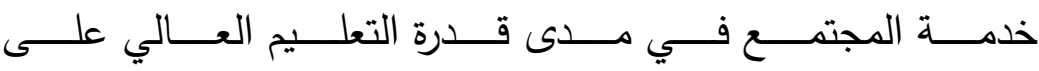
خدمة قضايا المجتمع واحتياجاته .

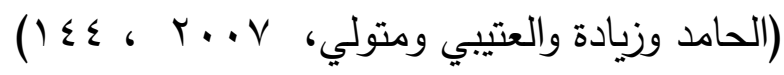

•كما أن استحداث الوظائف الأكاديمية في سنوات سابقة أثر في قلـة الكفايات الوطنية المؤهلة للتدريس في كليات وأقسام عملية جديدة

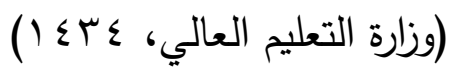

•زيادة المشكلات المتعقة بالتمويل تعقيداً مـع تتامي الاتجاهات التي تُنادي بالتمويل الحكومي فقط، يظل سبياً في عدم تمكن الجامعات

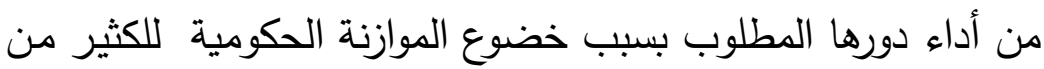
التأثيرات كالتذبذب في الموارد والتضخم وغيرها.

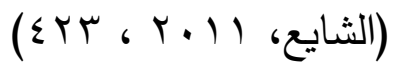


•كمـا أن المتتبع لإنتاجيـة أعضـاء هيئة التدريس من البحث العلدي

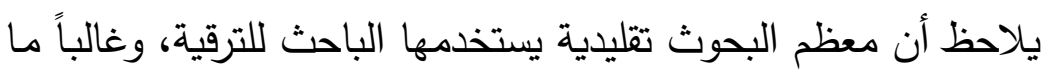

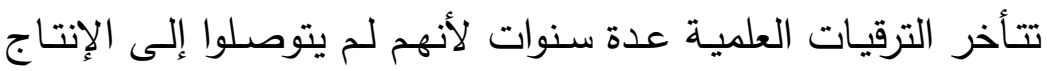

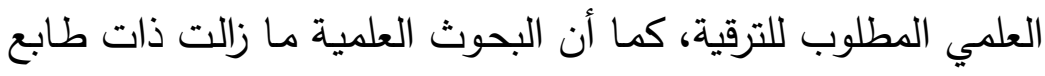

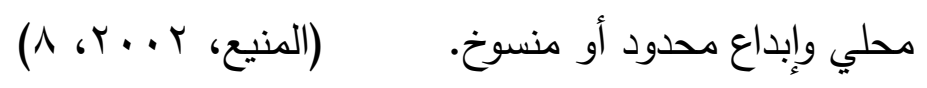

•يعاني التعليم العالي من غلبة البيروقراطية، والتي تحد من فعالية أداء

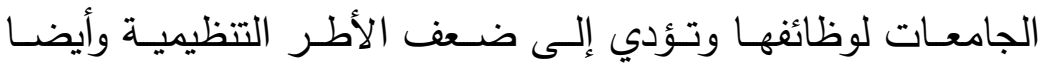

$$
\text { الهيكلية }
$$

هذه بعض التحديات الداخلية التي أثرت على حركـة التعليم العالي وتحقيق التتمية المحلية في المملكة العربية السعودية والتي تؤثر حـث

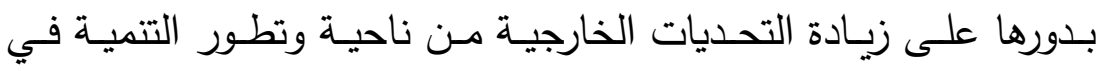

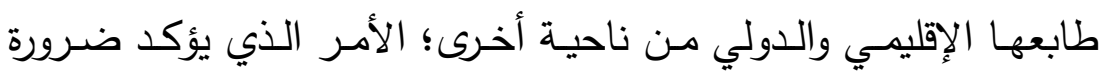
إحتكاك التعليم الوطني وتعايشه مع صيخ تعليم دولية منتقاة.

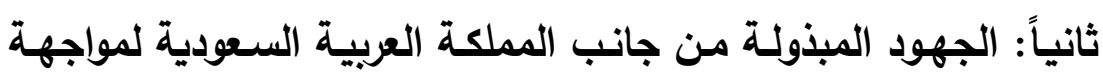
التحديات السابقة

إذا كانت هنالك تحديات فرضت نفسـها بطريقة أو بأخرى على العى

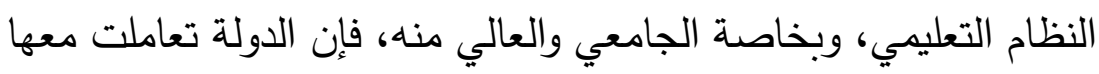

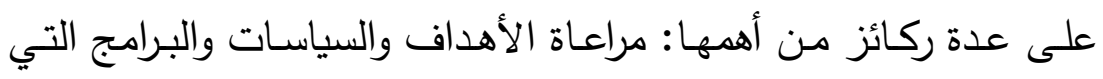
جاءت في خطط التتمية الخمسية للدولة، والإفادة من التجارب العالمية.

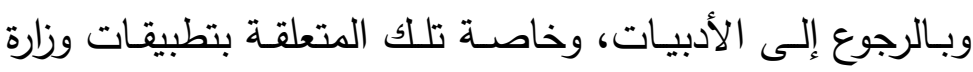

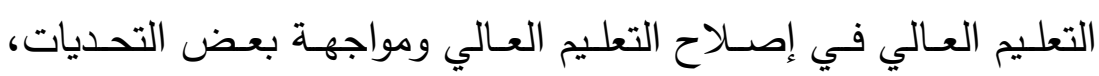
ومنها:

مشروع المنح الدراسية لطلاب وطالبات التعليم العالي الأهلي،

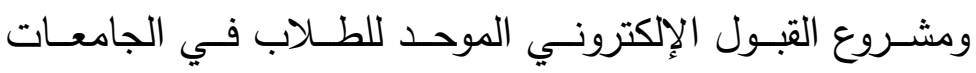

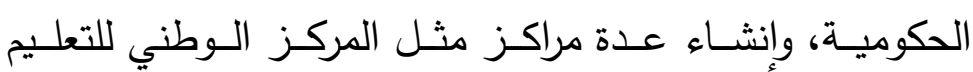


الإلكترونـي والتعليم عن بعد، ومراكز التميز البحثي، ومركز

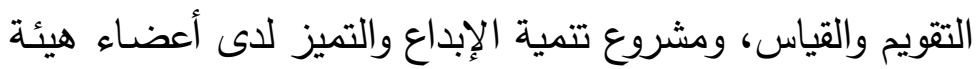
التدريس في الجامعات السعودية، وإنشاء صندوق التعليم العالي

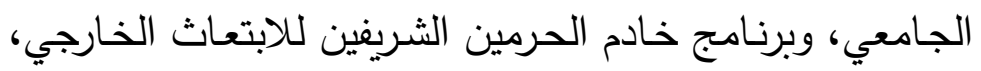

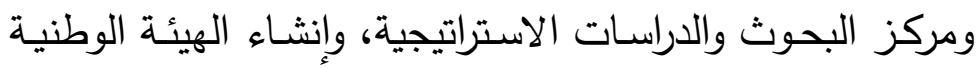
للتقويم والاعتماد الأكاديمي وغيرها

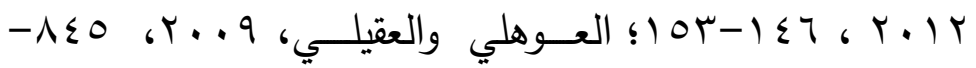
.$(\wedge \leq q$

زيادة فرص القبول والاستيعاب في مؤسسات التعليم العالي حتى

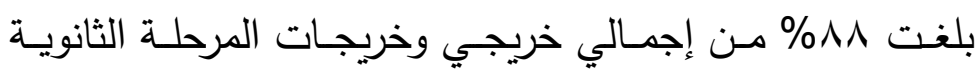

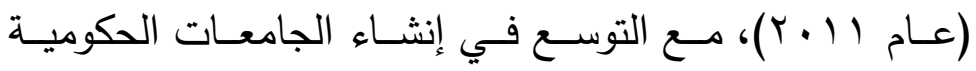

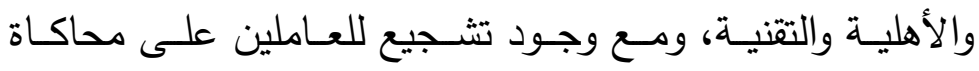

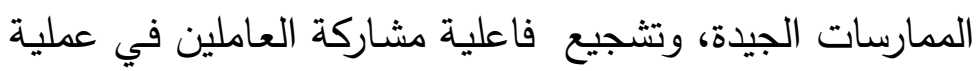

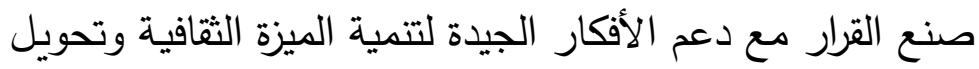
المعرفة الضمنية إلى معرفة معلنة وتفعيل دور وسائل الإعلام وتوظيفها في نقل المعرفة

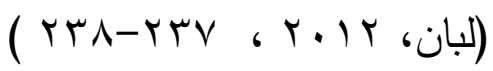

الاعتماد على تطوير منظومة التعليم العالي عبر مجموعة من

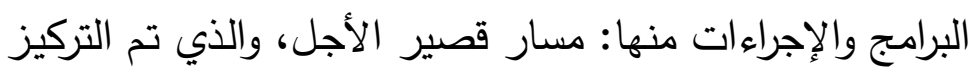
فيه على قضـايا القبول والاستيعاب والمواءمة مـع سوق العمل.

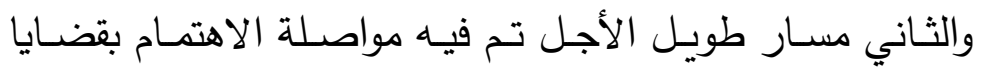

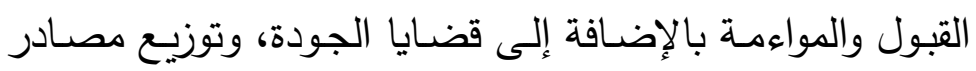
الدخل، والبحث العلمي، والابتعاث وتحديث التنظيمات الإداريـة 
والتعلـيم العـالي، والثـراكات الدوليـة والتخطـيط الاسـتراتيجي.

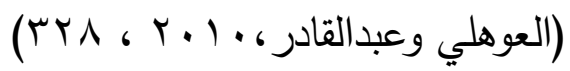

دراسة إيجابيات الانتشار الجغرافي والعمل على تكامل مؤسسات التعليم العـالي في صياغة منظومـة وطنيـة فاعلـة ودراسـة سبل لخديل إدارة فروع الجامعـات والكليـات مـع تقويم عمليـة تمويـل التعليم

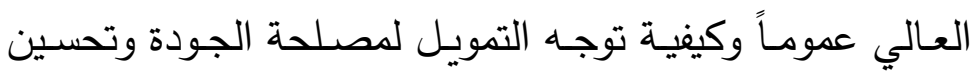

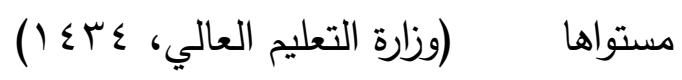

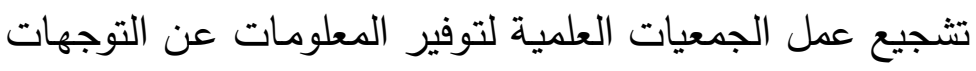
العالمية في التتمية والاقتصاد ودور الجامعات في توفير تقارير وتكوين لجان لدراسة ضبط التعليم العالي والجامعي في المملكة،

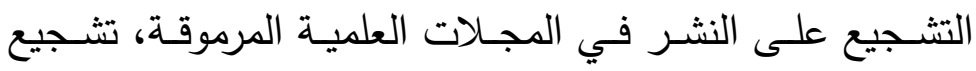
الجامعات على الاهتمام باقتصاديات المعرفة.

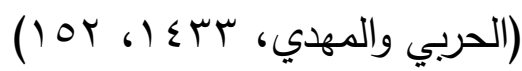

تبني بعض المبادرات التي تساعد على الإسهام الإيجابي في

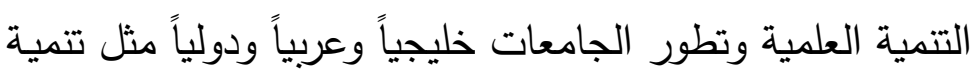

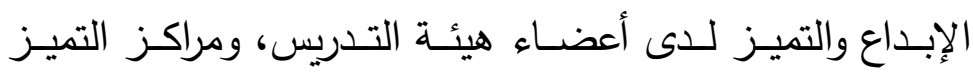

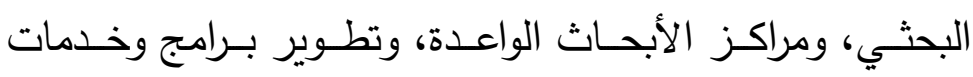

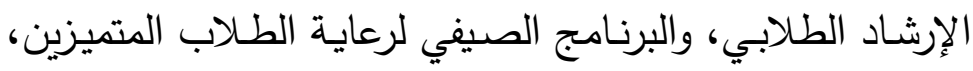
وتطــوير الأقسـام العلميـة في الجامعـات السـعودية، والقيـادة

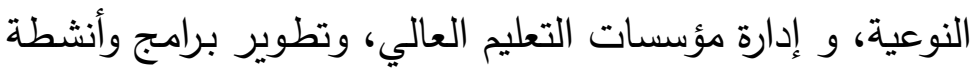
الجمعيات العلمية في الجامعات السعودية، وتطوير استراتيجيات وطرق التعلم المتمركز حول الطالب، والمشروع الوطني لقياس

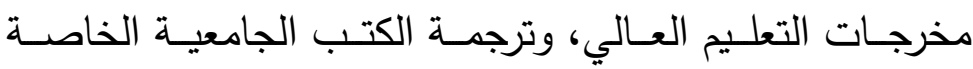

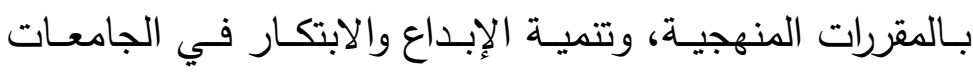
السعودية، وتعزيز المسؤولية الاجتماعية للجامعات السعودية . 
(كعكي، r ( )

وعلى الرغم من كل المجهودات السـابقة، فما زال المردود منها

أقل من المستوى المنشود والمستهدف، الأمر الذي يقتضي الاستفادة من كن

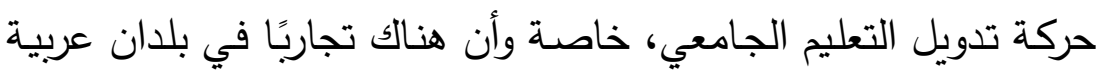

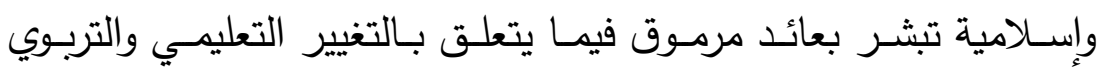
المطلوب.

ثالثا: التعليم العالي العابر للحدود

تعتمد القدرة التتافسية للدول بصورة متزيدة على القدرة على تعزيز

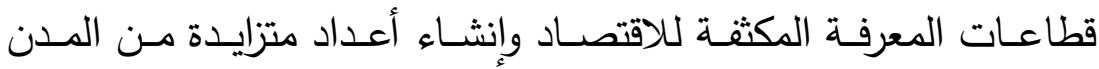
والمنـاطق الحضـرية التي تستهدف الصـناعات المعرفية وتسعى لتعزيز ملـيز البحوث والتكنولوجيا والملكية الفكرية، والتعليم.

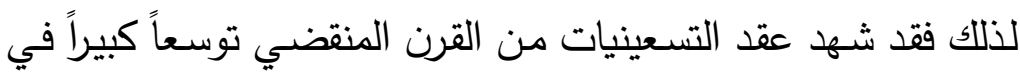

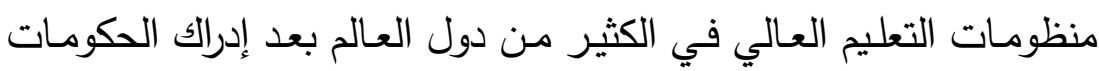

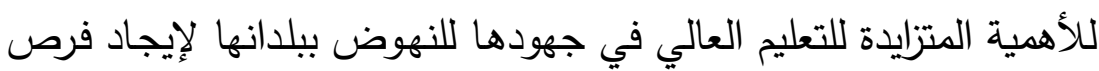
عمل لمواطنيها وتأمين منافسة قوية لمنتجاتها في الأسواق المحلية والدولية

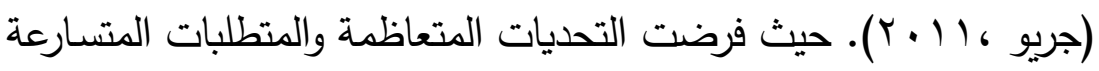

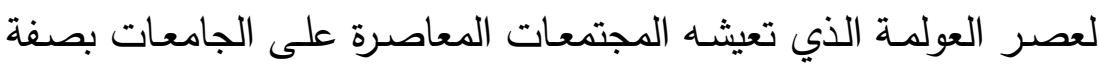

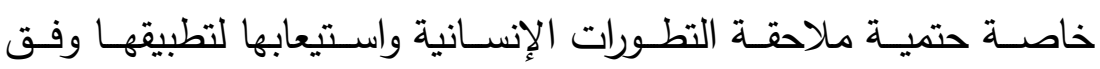
الأولويـات بمـا يسـاعد كل مجتمـع على الإسـهام الحقيقي في عمليـات

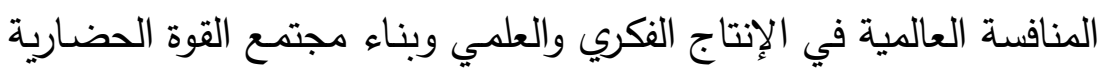

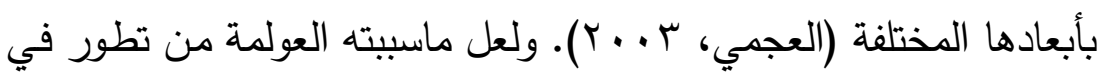

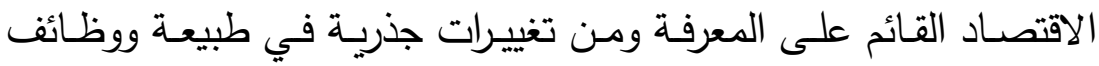
التعليم العالي في جميع أنحاء العالم كان أحد الاتجاهات الرئيسة المتعلقة

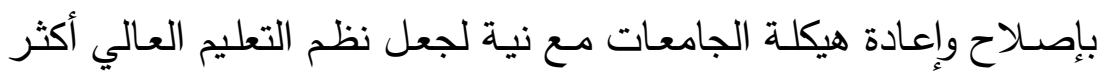
تنافسية على الصعيد العالمي. (Mok,2007) كما أن من نتائج العولمة أن 
اصـبحت المعرفـة سـلعة قـادرة على التتقـل بـين الـدول. وقــــ أدى نمـو الاقتصاد المبني على المعرفة إلى ازدياد المنافسة بين أصحاب الأعمال

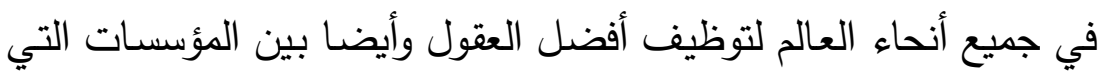
تقوم بتدريب هذه العقول (Arokiasamy, 2011). ومنذ ظهور الاتفاقية العامة للتجارة في الخدمات (GATS) في عام 990 199، كان هناك ضغط دولي من أجل تحرير التعليم العالي في جميع أنحاء العالم. (2010, Verger) فالهدف الأساسي من الاتفاقية هو تحرير التجارة الدولية، وتوطيد دعائم نظام تجاري عالمي، يقوم على اقتصـاد

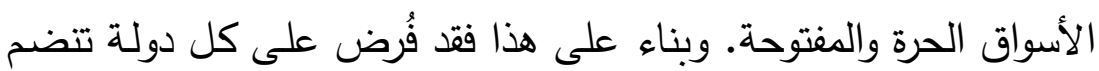

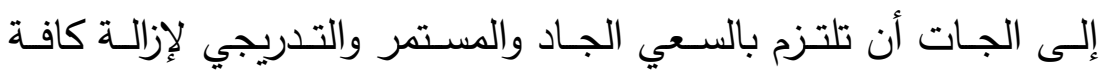

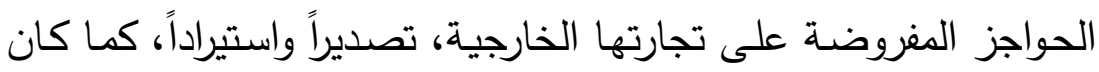
الغـرض هـو العمـل على إلغــاء القيود الجمركيـة على التجـارة الدوليـة والاستمرار في إجراء مفاوضـات متعددة الأطراف بصفة دوريـة لتحقيق هذا الغرض (Nyahoho, 2011).

ولعل من أهم أسباب الاهتمام بالبعد الدولي أن الكفايات المهنية والأكاديمية التي يفترض توافرها في خريجي الجامعات تعكس متطلبات

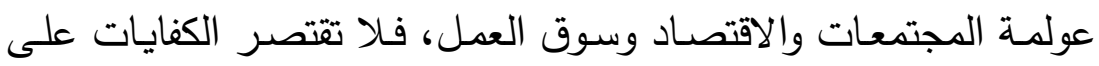
الجوانب المعرفية فقط بل تشمل أيضاً تعلم اللغات والمهارات والاتجاهات

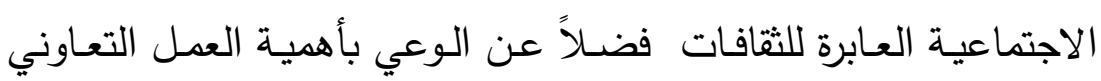
والمشاركة في مواجهة الكلفة العالية لمتطلبات البحث العلمي واستقطاب

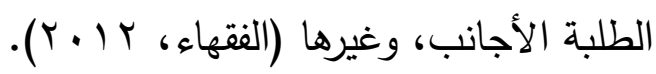

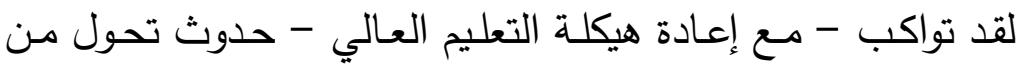

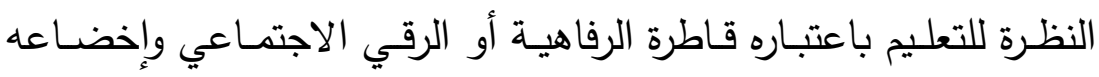

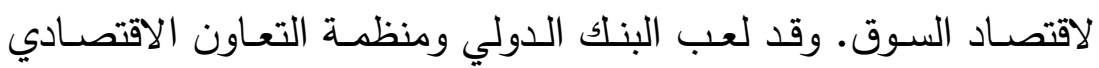

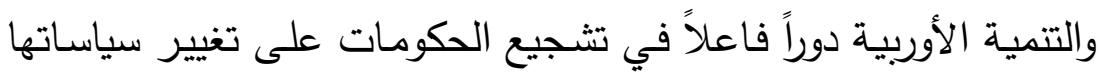




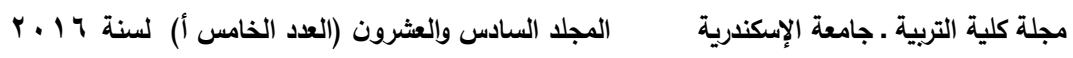

العامـة المبنية على الصـالح الاجتماعي إلى سياسـة مبنية على الصـالح الاقتصادي.

والتقرير الصـادر من البنك الدولي سنة ؟99 ام يحث دول العالم على أن تقلل من ازدياد اعتماد الجامعات على مصدر تمويل واحد وهو لموري

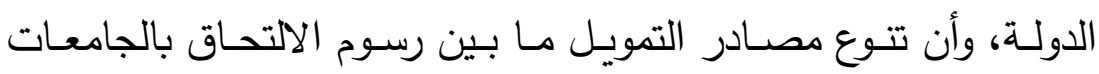
والاستشارات والتبرعات. (Arokiasamy, 2011) ويمكن تصـنيف أثـكال التعليم العـالي العـابر للحسدود كمـا يلـي:

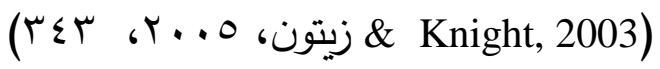
- افتتاح فروع محلية لمؤسسات تعليم عال أجنبية. - امتياز تقدمه مؤسسة تعليمية أجنبية إلى مؤسسات تعليمية محلية من فن فئل خلال تقديمها لبرامجها الدراسية.

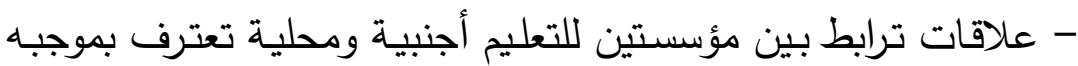
المؤسسة الأجنبية بالمؤهلات الممنوحة في المؤسسات المحلية.

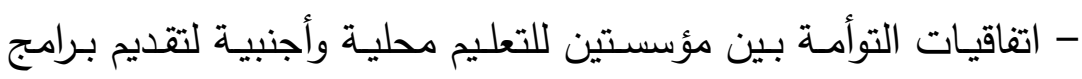
مشتركة.

- برامج للتعليم عن بعد تقدمها مؤسسات تعليمية بالمراسلة أو الإنترنت أو عبر القنوات الفضائية.

- برامج تدريبية ودراسية تقدمها الشركات الأجنبية الكبرى للعاملين فيها أو المتعاملين معها عبر الحدود.

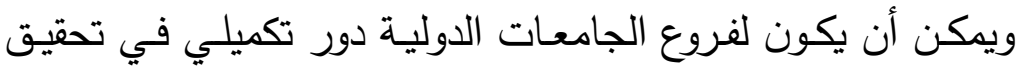
أغراض النمو الاقتصادي والاجتماعي للدول المستضيفة، كما أن لها دوراً تنافسياً لايقل أهمية عن الدور الأول يكمن في تفعيل العملية التنافسية مع الجامعات الحكومية وبين الجامعات الأهلية وبين فروع الجامعات الدولية لإنية نفسها للحصول على أفضل المخرجات التعليمية (عناقرة، و 9. . ب). 
فالهدف المنشود من فتح فروع لجامعـات عـابرة للحدود هو رفع نوعية وقدرات التعليم العالي، وكذلك للحد من المنح الدراسية في الخارج والتكاليف المرتبطة بها وإعادة توجيه جزء من هذه النفقات للدولة وطلاب المنح الدراسية، وأخيراً لخلق المنافسة بين مؤسسات التعليم العالي وتعزيز القدرات المحلية في مجال التعليم العالي (Aqeel, 2014). إلا أن هنالك خشية من تأثير هذه الفروع على بعض السلوكيات الاجتماعية

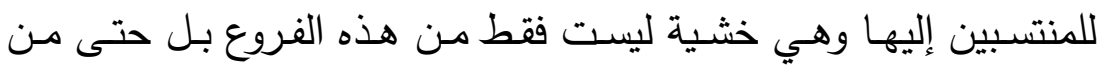
الإنترنت والقنوات الفضائية وغيرهـا. لكن مقارنـة مـا يحدث في الفضـاء الإعلامسي ويحصل للدارس في الخارج أو المبتعثين فإن الاثار ستظل معارنه محدودة أمام الفوائد التي ستجنى من افتتاح هذه الفروع داخل البلاد لأنه الإنه

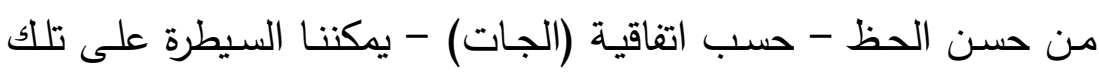

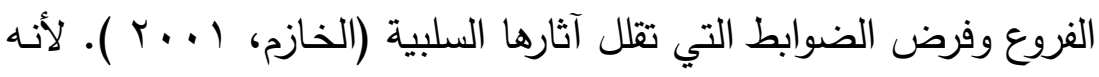

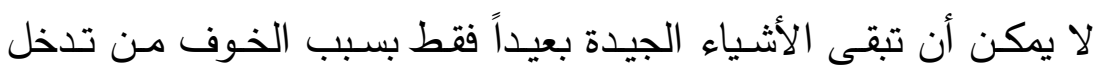

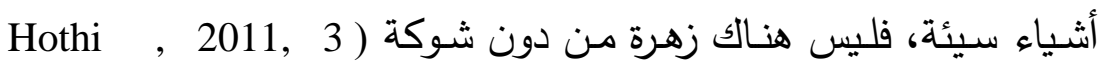
(Sardana \& وقد أعدت اليونسكو دليلاً إرشادياً لمراقبة نوعية التعليم العالي العابر

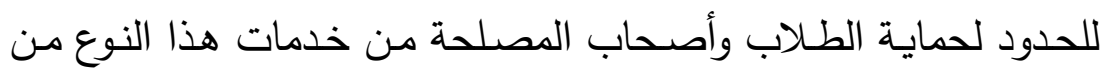
التعلـيم ذات المسـتوى المتـدني ومقـدمي الخدمـة ذوي السـمعة السـيئة (Unesco, 2005)

وقد اتبعت دول مثل الإمارات العربية المتحدة وقطر وماليزيا سياسات محددة لتشجيع استضافة فروع للجامعات عابرة الحدود كاستراتيجية للتمية الاقتصـادية وكوسيلة لتطوير قدراتها بسرعة. وقد طلبت هذه الحكومـات

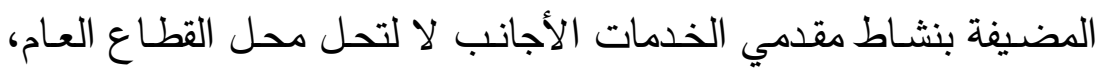

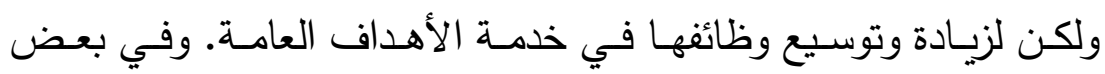
الحالات التمويل يأتي إلى حد كبير من الحكومة أو كيانات تسيطر عليها 
Lane \& ～الحكومة لتصبح هذه الفروع جزءا من النظام التعليمي بها Kinser, 2011 الدكتوراه. ويمكن عرض بعض ملامـح التجارب الدولية في إنشاء فروع إنى للجامعات العابرة للحدود كما يلي: الإمسارات العربية المتحدة: توجد فيها مدينة دبي الأكاديمية العالمية (DIAC)، وهـي أكبر منطقــة حـرة في العـالم مخصصــة للتعليم

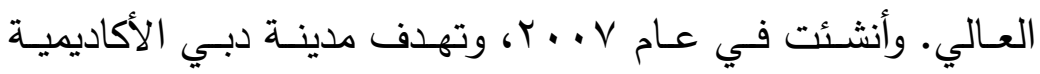

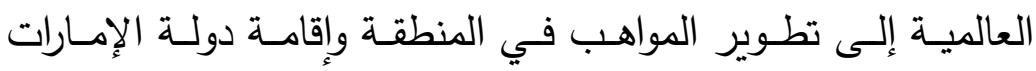

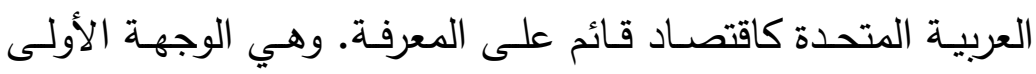

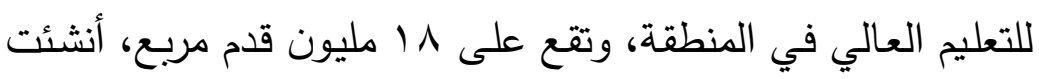

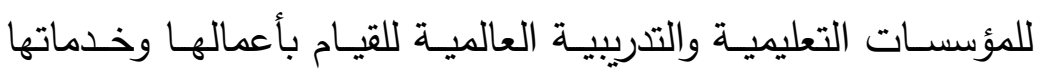
بملكية أجنبية محضـة. وتستضيف r r مؤسسة للتعليم العالي عابرة للحدود مـن • ( بلدان (Clark , 2015 a)، مثل فروع لجامعـات

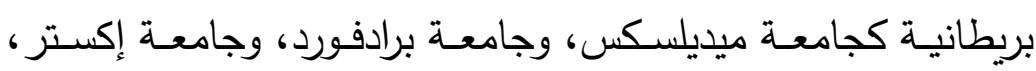
وجامعة هيريوت وات، وفروع لجامعات روسية مثل: جامعة سانت

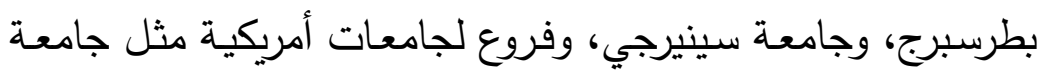

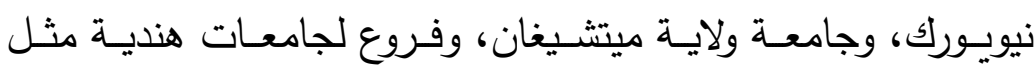

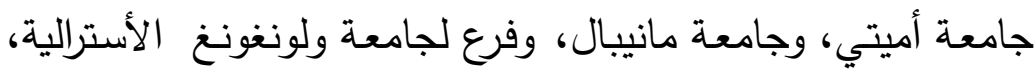

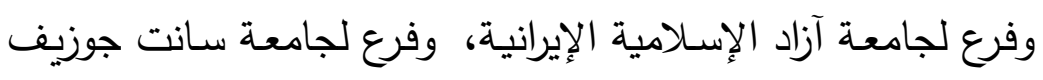

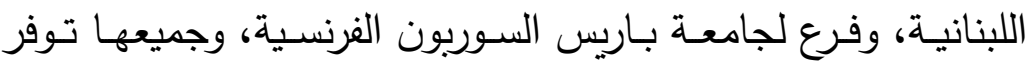

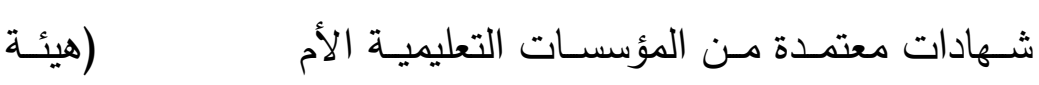

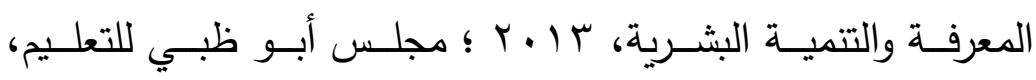

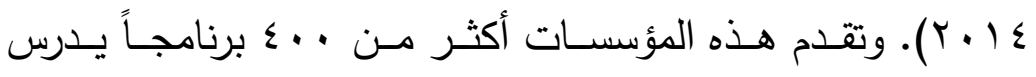

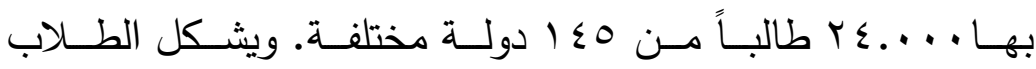


المغتربـون أكثـر مـن نصـف الطــلاب المنتسـبين لهـــه الفـروع .(Clark, 2015 a )

قطر : افتتحت مؤسسة قطر للتربية والعلوم وتتمية المجتمع المدينة

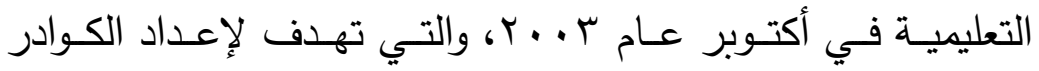

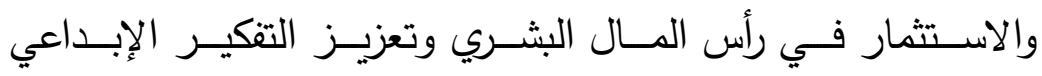

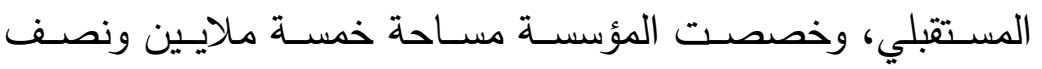
المليون متر مربع من الأراضي من أجل تطوير المدينة التعليمية،

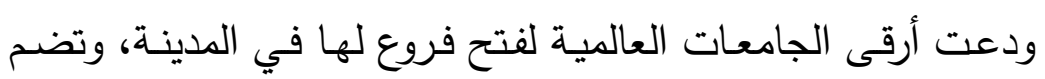

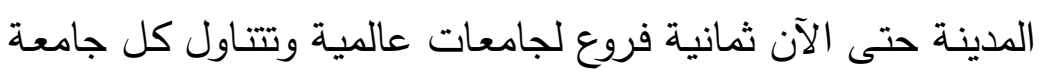

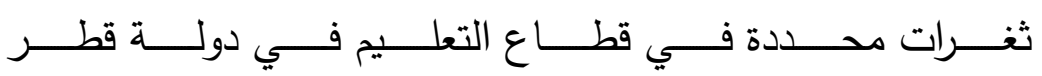
(Fielden , 2012 , 6) عـابرة للحدود مثل جامعـة تكسـاس أي آنــ إم، وجامعـة كـارينجي

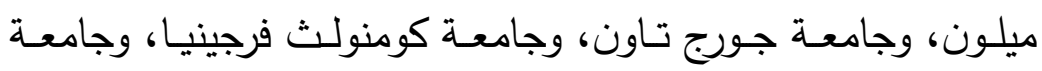

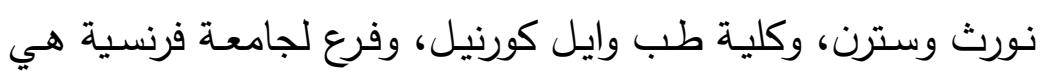
لإبدارة ليات العلي لـة الدراسـ

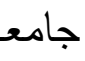
(المجلس الأعلى للتعليم، ـ ( • ب). وهنـالك عـد مـن المؤسسـات

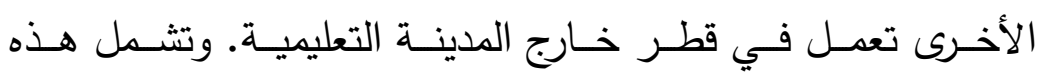

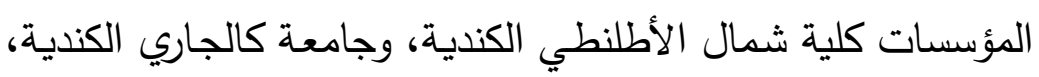
وجامعة ستتدن الهولندية (Clark, 2015 a).

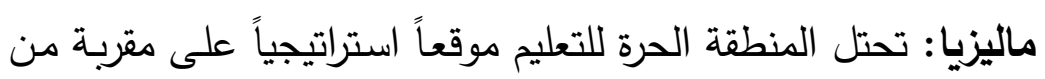

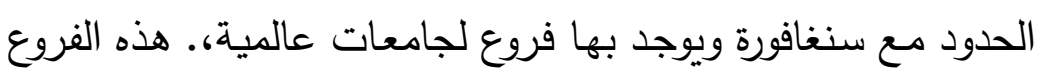

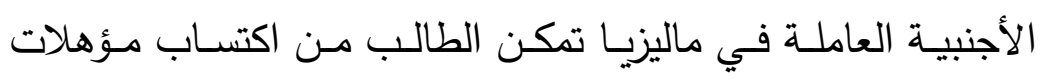

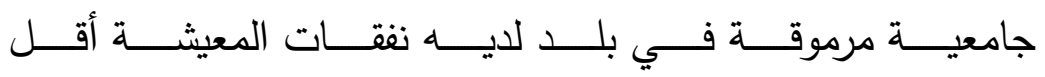
(Clark , 2015 b) للحدود مثل جامعة مونـاش، وجامعة كورتين للتكنولوجيا، وجامعة لونة 
ســوينبرن للتكنولوجيـا، وفـروع لجامعـات بريطانيـة مثـل جامعــة نوتنغهام، وجامعة نيوكاستل، وجامعة ساوثهامتون، وجامعة ريدينج،

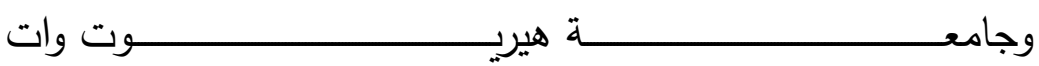
(Ministry Of Higher Education, 2010) جامعـة مانيبـال الدوليـة، ومسن أيرلنـــا الكليـة الملكيـة للجـراحين (Clark , 2015 b)

ويلاحظ هيمنـة الولايـات المتحدة الأمريكيـة وبريطانيـا وأسـتراليا

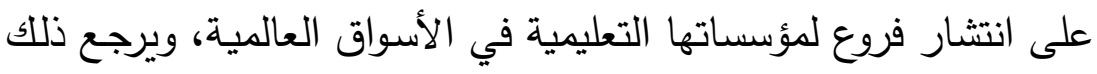
إلى ثلاثة أسباب هي (Wilkins \& Huisman, 2012): - كون لغة التدريس هي اللغة الإنجليزية. - انخفاض مستوى التمويل الحكومي والبحث عن مصادر بديلة. - الإصـاحات التي شـملت مختلف نـواحي الحيـاة في هـذه البلـدان، وبالتالي أصبحت أكثر ملاءمة للذهاب إلى الأسواق العالمية.

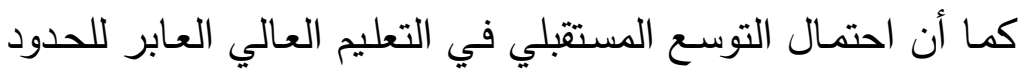

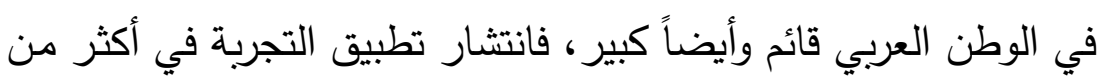

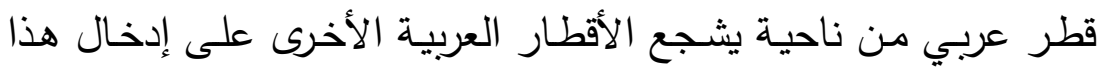

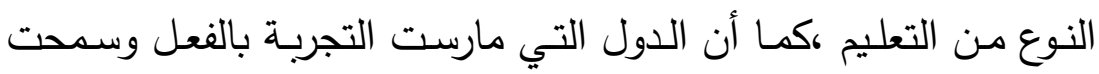

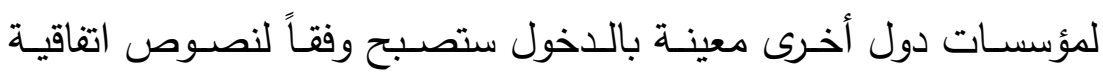

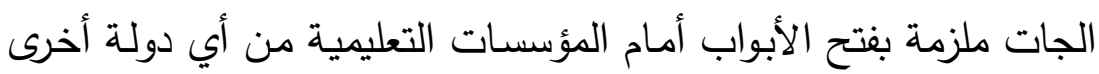
(زيتون،

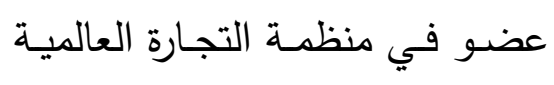

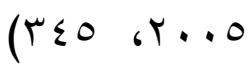

وانضمام المملكة العربية السعودية إلى منظمة التجارة العالمية هو

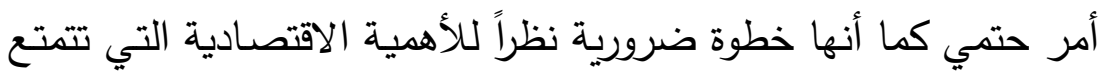
بها المملكة عالميا. وحقيقة الأمر أن اتفاقية الجات تنص على على تطبيق الفيق

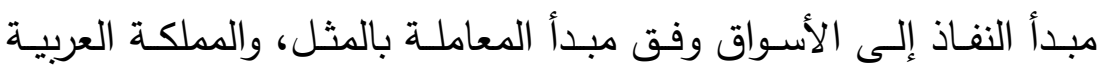


السعودية اتفقت على فتح الخدمات التربوية أمام الموردين الأجانب في

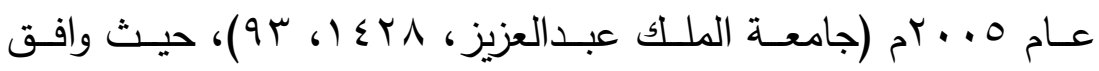

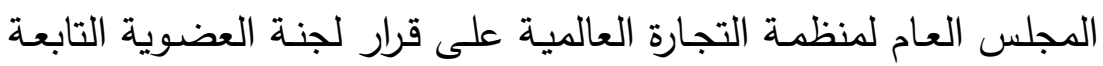
للمنظمـة بأن السعودية حققت كل شروط العضوية. وبذللك يمثل التعليم بكافة مراحله معظم قطاع الخدمات التربوية التي تم الاتفاق على تحريرها

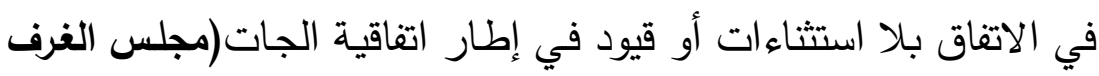

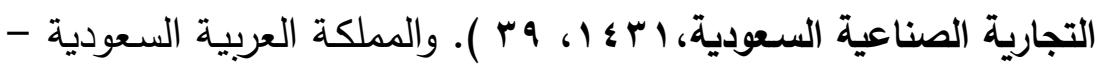
باعتبار أن اقتصادها مفتوح - ترغب في تحديث نظام تجارتها ولكن في

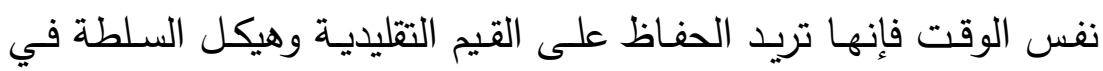
الـبلاد (Bagaresh, 2013). بالإضـافة إلـى اسـتقرارها الاجتمـاعي والسياسي، وتمتعها بموقع جغرافي مميز بين دول المجموعـة الآسيوية

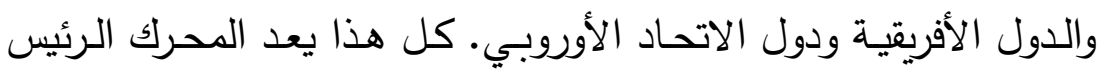
لجذب شركاء أجانب في مجال التعليم العالي.

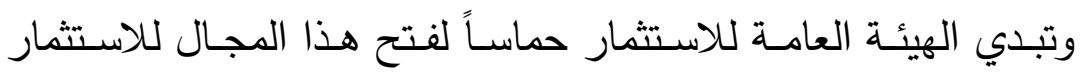

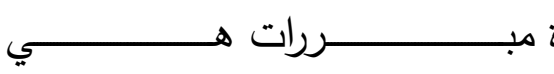
مد الأجنب

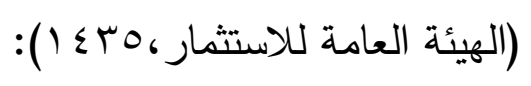

الطلب المتزايد على مستويات التعليم المختلفة.

التوزيـع السـكاني الـديموغرافي في المملكـة العربيـة السـعودية

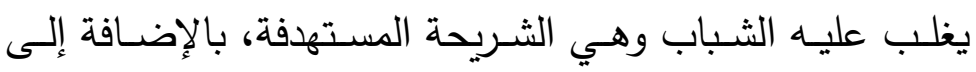
ملايين الأطفال.

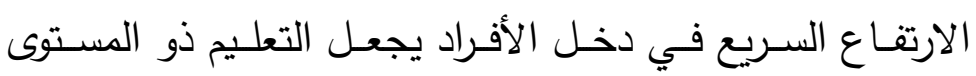
العالمي في متتاول العائلات السعودية. تقوم المملكة العربية السعودية ببناء المدن الاقتصادية في إطار حملة عامة طموحة للاستثمار داخل المملكة، وذلك لاستقطاب 
الصـناعات كثيفــة التكنولوجيـا القائمسة على المعرفـة وإتاحـة الفرصة للمؤسسات الأجنبية للمشاركة.

ويؤكد ما سبق عرضده - على المستوى النظري - أهمية التلقيح الثقافي بـين مؤسسـات التعليم الجـامعي الوطنيـة وجامعـات أجنبيـة لهـا

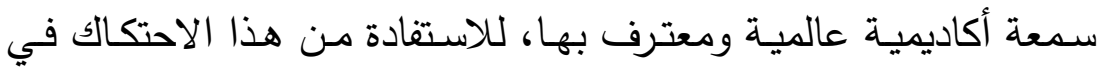
تحقيق قفزات نوعيـة في التعليم الجـامعي للارتقاء بـه لمسـايرة المستوى

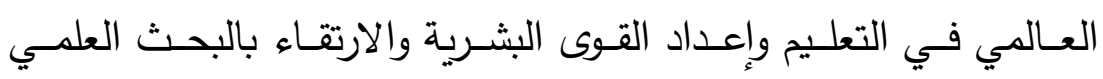
والتطوير التكنولوجي وخدمة المجتمع.

\section{الاراسات السابقة}

تم انتقاء أكثر الدراسات ارتباطاً بالموضوع، نعرضها وفق التسلسل لاعل التاريخي لإجرائها من الأقدم إلى الأحدث على النحاء النحو التالي: بالي:

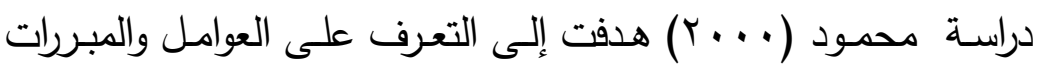
التي تستدعي تدويل التعليم العالي، واستخدمت الدراسة المنهج الوصفي

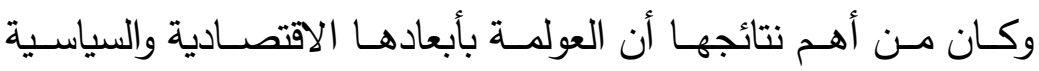

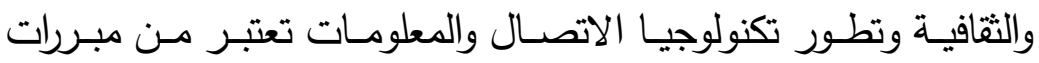
تدويل التعليم العالي.

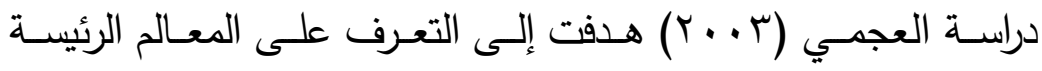

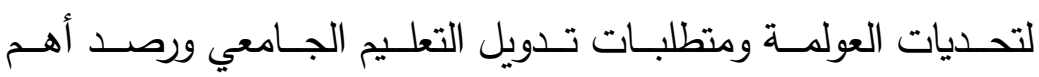

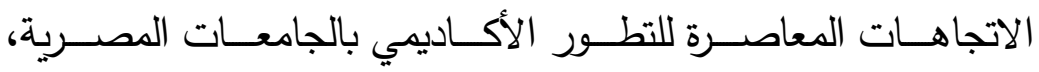

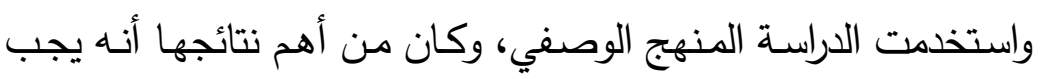

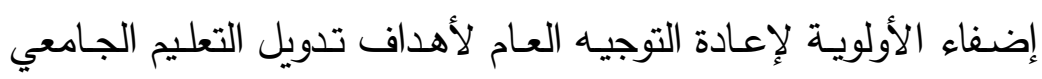

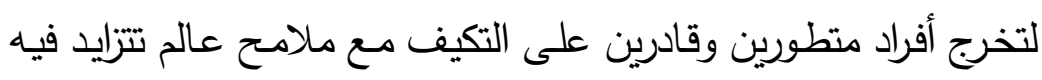
درجات التعقيد والتشابك.

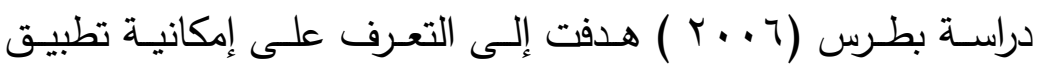

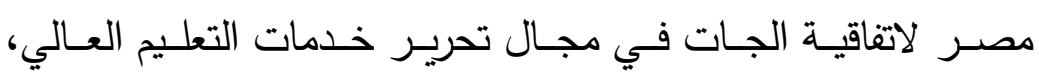


واستخدمت الدراسـة المنهج الوصفي، وكان من أهم نتائجها أنه على

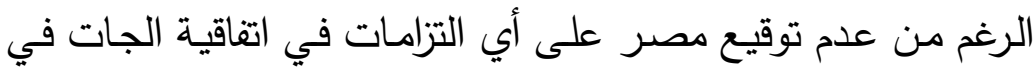
مجال التجارة في الخدمات التعليمية إلا أن جميع صور لحئ تحرير التجارة في الخدمات متوفرة. دراسة ديفد وداني (David \& Danny , 2006) هدفت إلى التعرف على طرق تتظيم وإدارة التعليم العالي العابر للحدود في الصين والهند، واستخدمت الدراسة المنهج الوصفي، وكان من أهم نتائجها وجود ثلاثة

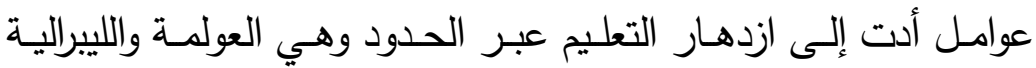
الجديدة واتغاقية الجاتس.

دراسة أولدز (Olds, 2007) هدفت إلى التعرف على أهداف السياسة

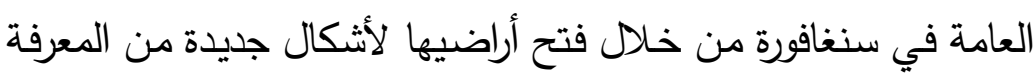

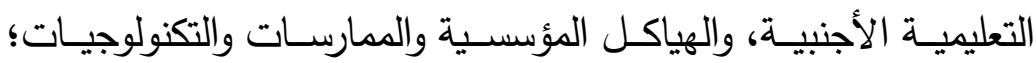
وكان من أهم نتائجها أن الجامعات الدولية عند دخولها اعتمدت على التى تشكيل الروابط بين الجامعة والصناعة في سنغافورة.

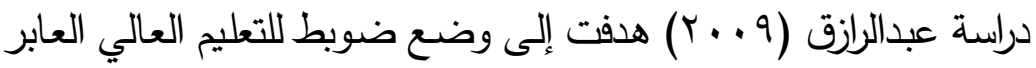
للحدود القوميـة وتحليل خبرات ماليزيـا والصين في مجال التعليم العابر للحدود. واستخدمت الدراسة المنهج المقارن وكان من أهم نتائجها التأكيد على أهمية الاستثمار في التعليم وفي البنـى التحتية وأن تكون مصـر لهر مصدر جذب للطلاب المحليين والأجانب وذلك بتوفير برامج تعليمية

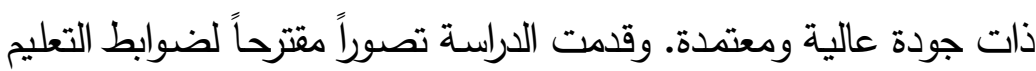
العالي العابر للحدود القومية بمصر • دراسة ويت (Witte, 2010) هدفت إلى التعرف على فروع الجامعات الدولية في دول الخليج العربي. واستخدت المنهج الوصفي. وكان من أهم نتائجها أن هناك توسعاً سريعاً في عدد فروع الجامعات الدولية في 


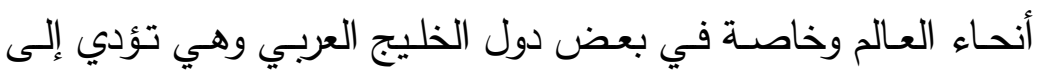
زيادة القدرة التتافسية العالمية.

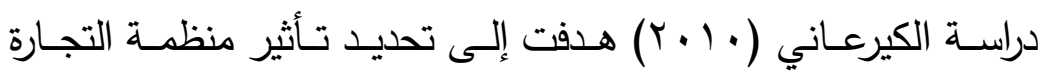

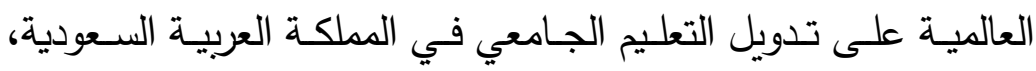

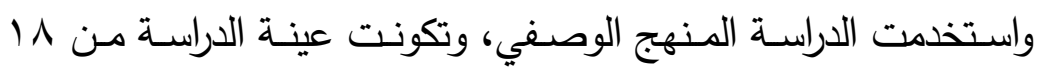

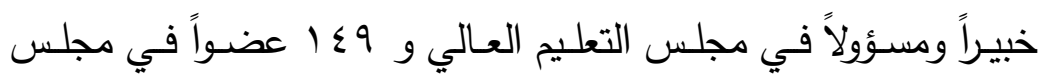

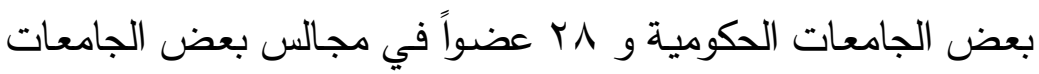

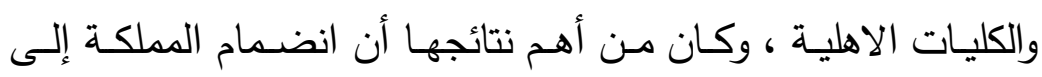

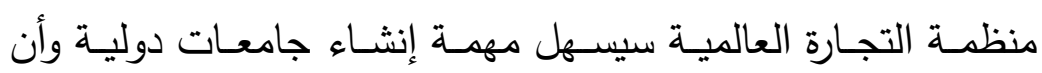
المجتمع السعودي مؤهل لاستيعاب الثقافات الأخرى. دراسة ميترا (Mitra, 2010) هدفت إلى التعرف على ملامح تدويل التعليم العالي في الهند. واستخدمت الدراسـة المنهج الوصفي، وكان الهـان

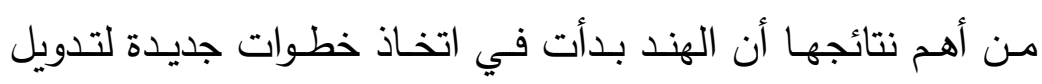

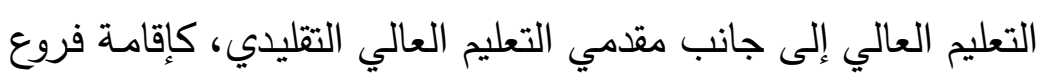
في البلاد للجامعات الدولية.

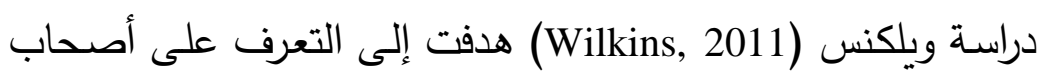

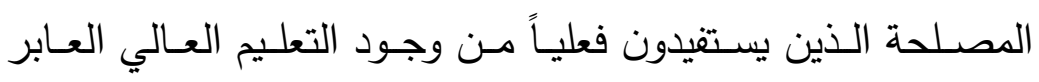

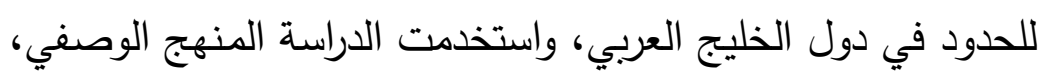
وكان من أهم نتائجها أن الشباب الذين يعيشون في هذه البلدان هم

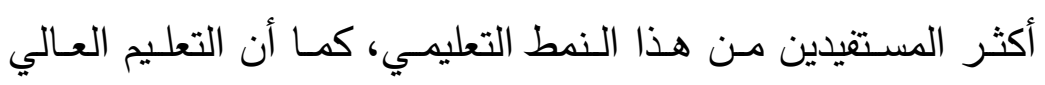

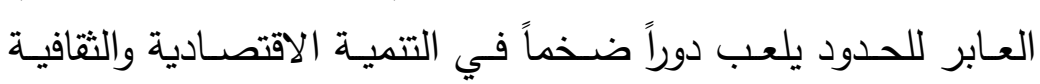

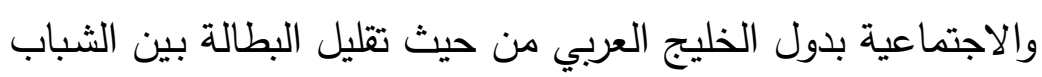

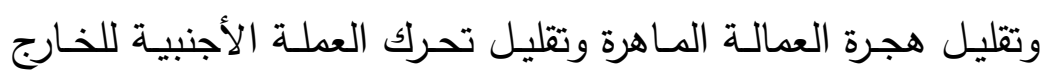
والتي يتسبب فيها هجرة المواطنين للخارج للدراسة، والأسهام في خلق اقتصاديات متتوعة تقوم على المعرفة. 
دراسة ساردانا وهوث (Sardana \& Hothi , 2011) هدفت إلى التعرف على تأثير الجامعات الدولية - إذا فتح الباب لها - على هلى نظام التعليم الهندي. واستخدمت الدراسة المنهج الوصفي، وكان من أهم نتائجها أن دخول الجامعات الأجنبية في الهند سيرفع بالتأكيد المسـتوى العـام لنظـام التعليم في الهنـــــومـن مزايـاه وقفف هجرة

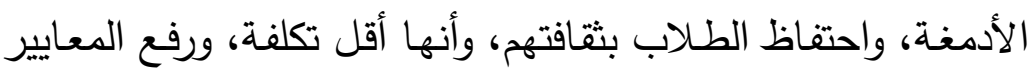
الأكاديمية للجامعات الهندية. ومن عيوبه الدافع التجاري. ومثل هذه الجامعات ستزيد من تعزيز قدرة الطالب على الإقامة في الخارج.

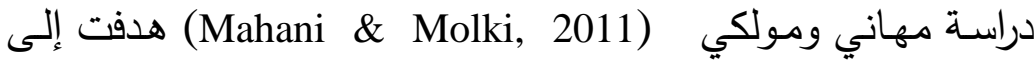
التعـرف على الاتجاهـات الحاليـة في تـدويل التعليم العـالي في هي هـي الإمارات العربية المتحدة. واستخدمت الدراسة المنهج الوصفي. وكان من أهم نتائجها أن بعض مؤسسات التعليم العالي تتجه بشكل متزايد

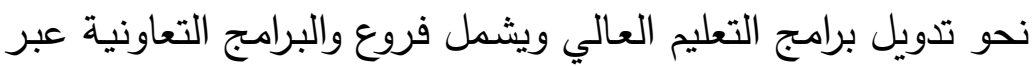

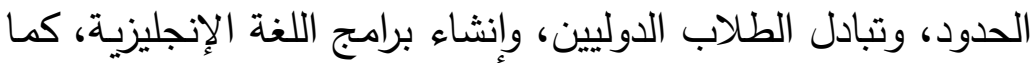
أنها تعتبر كمركز إقليمي للتعليم على مستوى عالمي من خلال دعوة الجامعات البارزة لإنشاء فروع لها في البلاد . دراسة خضر (Khodr, 2011) هدفت إلى التعرف على القوى الدافعة

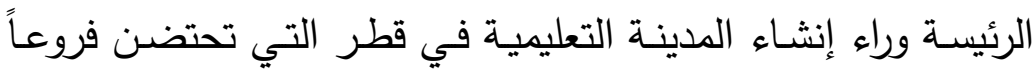

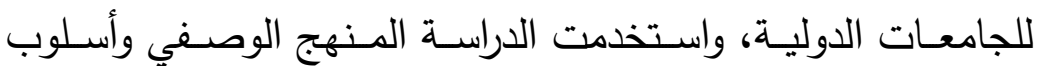

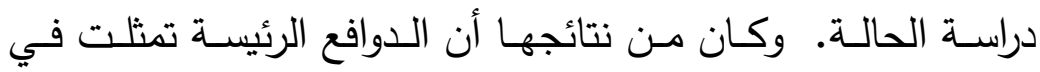

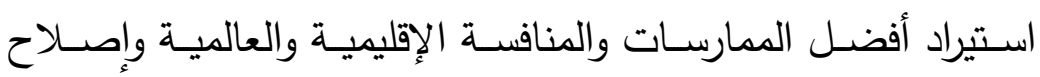
التعليم والسياسات المحلية ومبادرات التحرر الوطني والعولمة.

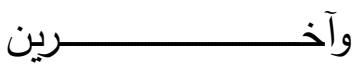
زي

(Zeeshan, Sabbar, Bashir \& Hussain,2013) على دافع الطلاب الدوليين للدراسـة في ماليزيـا. وطبقت على عينة 
تكونت من • 11 طالباً دولياً في ماليزيا. واستخدمت الدراسة المنهج

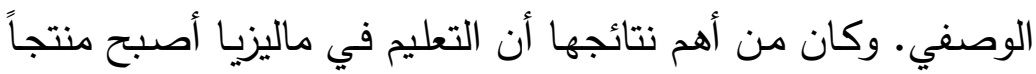
تجارياً في الساحة الدولية.

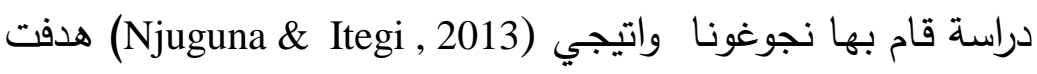
إلى رصد أنماط واتجاهات التعليم العالي العابر للحدود في كينيا. واستخدمت الدراسة المنهج الوصفي. وكان من أهم نتائجها أن التعليم

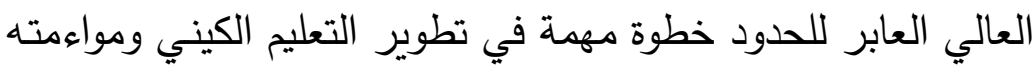
للمعايير الدولية، ومن فوائده الحفاظ على القدرة التنافسية الاقتصادية وتعزيز التفاهم بين البشر وتدفق التكنولوجيا وتعزيز الاقتصاد القائم على المعرفة. دراسـة إجل وأستا (Egle \& Asta, 2014) وهدفت إلى توضيح الدوافع والمبررات من إنثاء فرع الحرم الجامعي في الخارج. وكان

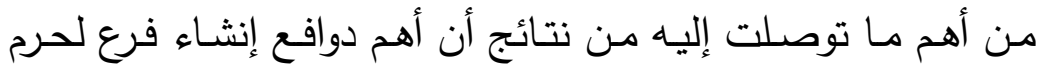
جامعي في الخـارج هي دعم وتشجيع الحكومات لمبادرات تصدير

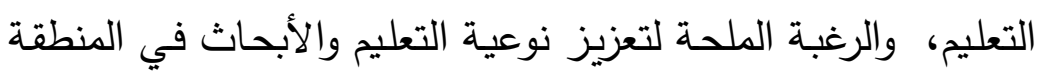
وتوليد دخل إضافي، والحد من هجرة العقول.

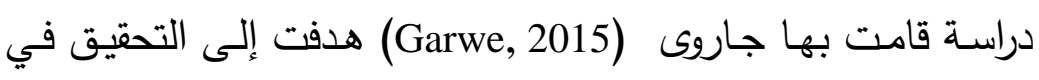
قضايا الجودة المرتبطة بالتعليم العالي العابر للحدود في زيمبابوي. واستخدمت الدراسة المنهج الوصفي. وكان من أهم ما توصلت إليه

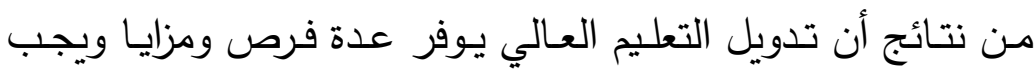

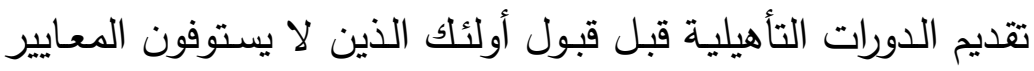
المطلوبة في البداية للاخول. التعليق على الاراسات السابقة: 
هنالك تباين بين عنوان الدراسـة الراهنـة وعنـاوين الدراسـات السـابقة، وكذللك في الأهداف وبنية الدراسة ومع ذلك فهناك قواسم مشتركة بين الدراسة الراهنة والدراسات السابقة ولعل أهم هذه القواسم ما يلي: اتفاقها مع الدراسات السابقة في أهمية تدويل التعليم العالي باعتباره اتجاهـاً حديثاً لتطوير التعليم العالي التقليدي بالاضـافة إلى العائد

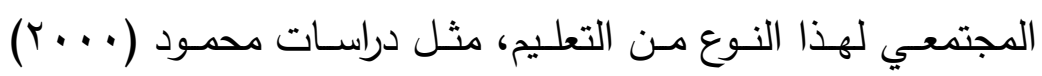

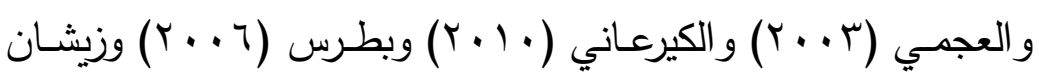
واخرون (Zeeshan, Sabbar, Bashir \& Hussain, 2013) وميترا (Mitra, 2010) ومهاني ومولكي (Mahani \& Molki, 2011) وجاروى (Cari) .(Garwe, 2015) تتشابه الدراسة الراهنة مـع الدراسات السابقة في تتاولها لبعض القوى

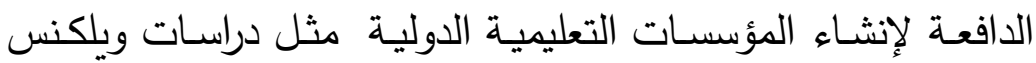
(Wilkins, 2011) (Sardana \& Hothi ， 2011) وخضر (Khodr, 2011) ونجوغونا (Na) واتيجي(Njuguna \& Itegi , 2013) و ويت (Witte, 2010) و ديفيد وداني (David \& Danny , 2006) واجلي واستا .(Egle \& Asta , 2014) تتشابه الدراسة الراهنة مع معظم الدراسات السابقة في استخدامها للمنهج

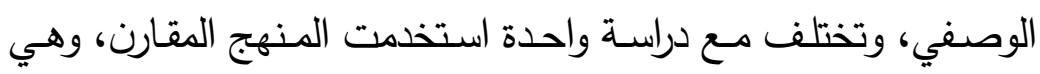
الدراسة التي قامت بها عبدالرازق (9 . . ب). واستفادت الدراسة الراهنة من الدراسات السابقة في بعض إجراء اتها

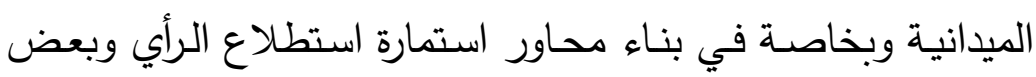
عباراتها. ومهع ذلك فإن الدراسـة الراهنة تتميز عن الدراسات السابقة بأنها من الدراسات التي تبحث عن الموجهات الدافعة نحو الترخيص

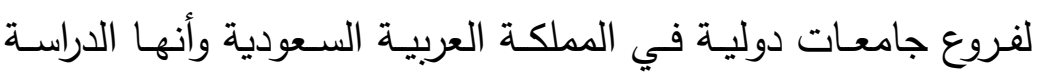




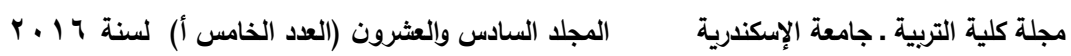

الوحيدة - في حدود علم الباحث- التي تتم في البيئة السعودية في

هذا المجال.

الاراسة الميد(نية

أهداف الدراسة الميدانية

- التعرف على موجهات الترخيص لفروع جامعـات عابرة للحدود في لهي

المملكة العربية السعودية.

- الكثـف عـن فـروق ذات دلالـــة إحصـائية بـين متوسـطات تقـدير

اسـتجابات العينـة على موجهات الترخيص لفروع جامعـات عـابرة

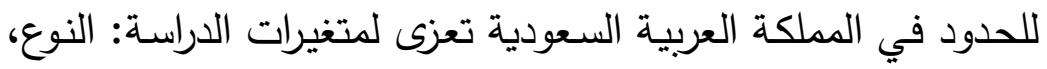

التخصص، الجنسية، الرتبة الأكاديمية.

مجتمع الدراسة

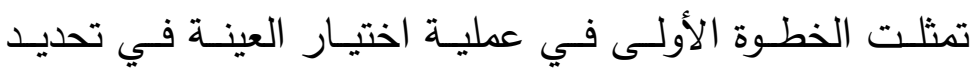

المجتمع الأصلي والذي يتمثل في أعضاء هيئة التدريس بجامعة الدمام

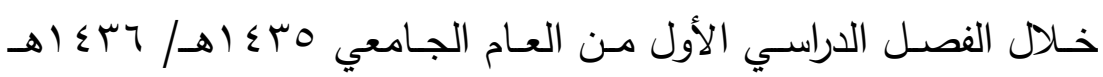

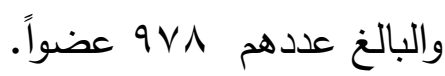

\section{عينة الاراسة وخصائصها}

لـمَّا كان من الصعب دراسـة المجتمع الأصلي بأكمله كانت الخطوة

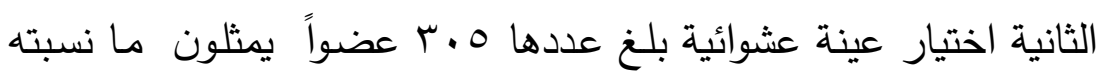

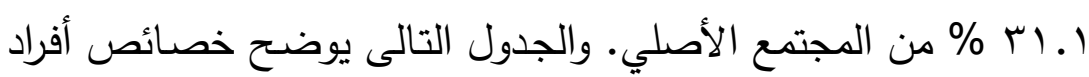
عينة الدراسة على النحو التالي: جدول (1) توزيع أفراد عينة الدارسة حسب متغيرات الدراسة و النسبة المئوية لها

\begin{tabular}{|c|c|c|c|c|}
\hline النسبة المئوية & التكرار & \multicolumn{2}{|c|}{ متفيرات الدراسة } & \\
\hline 04.1. & ivi & ذكر | ل الر & \multirow{2}{*}{ النوع } & \\
\hline$\{r .9$. & $1+4$ & أنثى & & \\
\hline or.s. & $14 \pi$ & 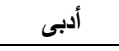 & \multirow{2}{*}{ التخصص } & \\
\hline 54.4 & $1 \leqslant r$ & علمى ( ل عل & & \\
\hline r... . & 114 & سعودى & \multirow{2}{*}{ الجنسية } & $\pi$ \\
\hline ir.r. & 194 & غيز سعودى & & \\
\hline
\end{tabular}




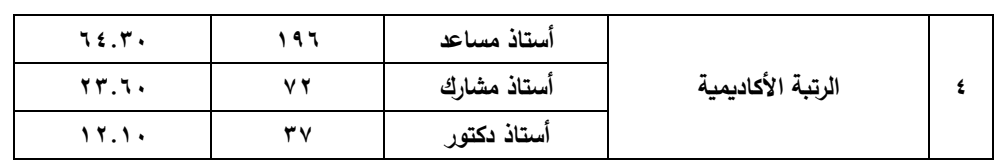

يتضح من الجدول السـابق أن عدد أعضـاء هيئة التدريس من

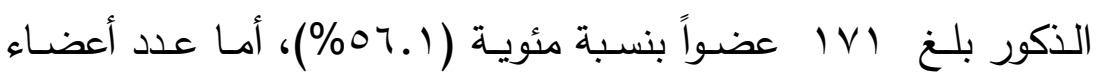

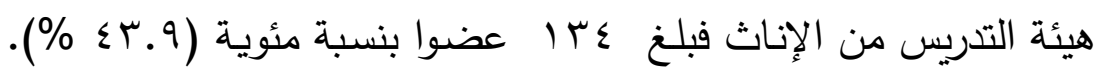

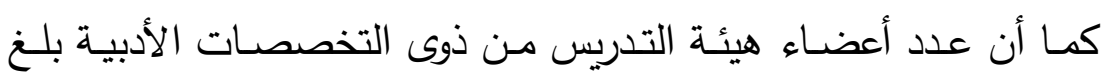

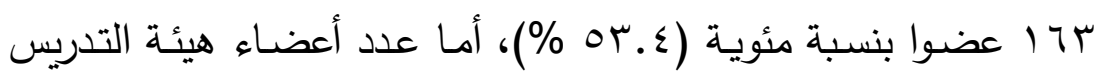

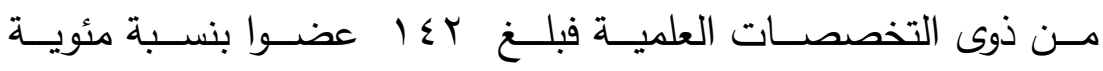

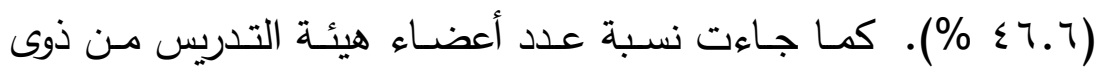

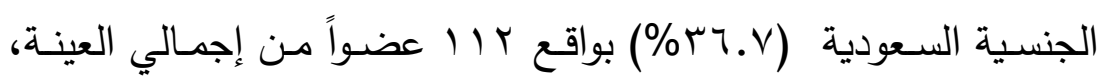
وبلغت نسبة أعضساء هيئة التدريس من ذوى الجنسيات غير السعودية

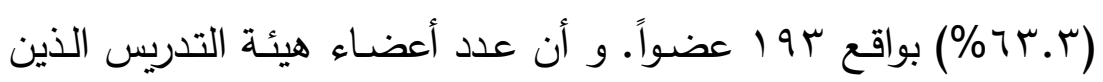

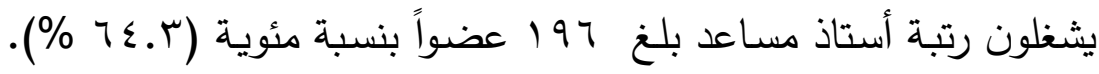

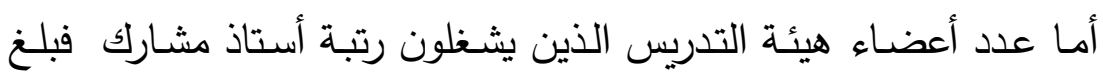

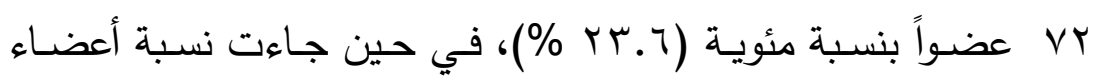

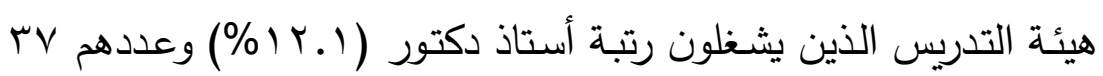
عضواً.

أداة الدراسة

أفـادت الدراسـة مـن معطيـات الدراسـات السـابقة والأدب التربوي في تصميم استمارة استطلاع رأي أعضاء هيئة التدريس و تتكون الاستمارة في صـورتها النهائيسة مـن أربعـة مجـالات رئيسـة هـي: المجـال الأول: الموجهات الاجتماعيـة، وحوى (^) عبارات؛ المجال الثاني: الموجهات

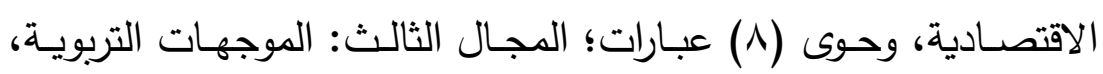

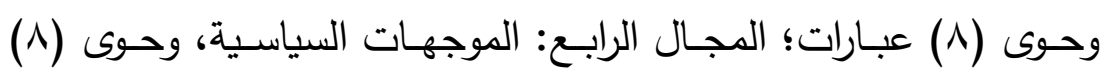

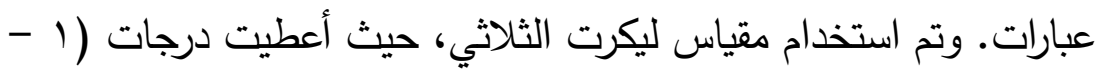


r - r r للاستجابات (ضعيفة - متوسطة - كبيرة) بالترتيب. ولأغراض تحليل وتحديد تقديرات استجابات العينة تم تصنيف تقديرات الطالبات إلى ثلاثة مستويات بحيث إذا كان الوزن النسبي بين (r. r. إلى r) يكون

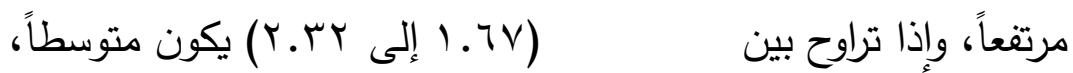

وإذا كان بين (1 إلى 17 . 1) يكون منخفضاً. ويلاحظ أن طول الفئة

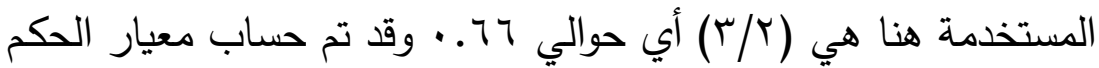
على قيم الأوزان النسبية وفق المعيار الثلاثي: تقنيـن أداة الدراســة قام الباحث بتقنين أداة الدراسة (استمارة استطلاع رأي) باستخدام الصدق والثبات كما يلي:

\section{صدق الاستمارة}

تم التحقق من صدق الاستمارة بالطرق التالية:

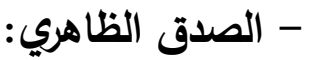
تم عرض الأداة في صورتها الأولية مرفقاً بها التعريفات الإجرائية لها على مجموعـة مـن أسـاتذة التربيـة وعلم النفس، لاستطلاع عآرائهم والاستفادة من خبراتهم وملاحظاتهم حول بنود الأداة من حيث الصياغة وملاءمتها للمجال ودرجة تحقيقها للهدف الذي وضعت من ون أجله وتمت الإفـادة مـن آراء المحكمين بالحذف والتعديل والإضـافة. ومن ثم إعـادة صياغة الاستمارة بصورتها النهائية. - الصدق باستخدام الاتساق الاخدلي 
تم حسـابه عن طريق إيجـاد معامل الارتباط بين العبارة والدرجـة الكلية للبعد الذي تنتمي إليه، وكذللك ارتباطها بالدرجة الكلية للاستمارة. والجدول التالي يوضح هذه المعاملات: جدول (ץ) يوضح صدق الاتساق الألي لمجالات الاستمارة

\begin{tabular}{|c|c|c|c|c|c|c|c|c|c|c|c|}
\hline لبالأل الارتباط & |الارتباط & رقم & 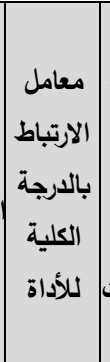 & |لالارتباط & العبارة & |لالارتباط & |الارتباط & رالعبارة & | لبالأل & | الارتباط & رقب \\
\hline 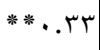 & **. & ro & $* * .09$ & $* * .71$ & IV & $* * 7$. & $* * .7 \mathrm{~V}$ & 9 & 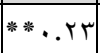 & ***.rV & 1 \\
\hline *.TV & $* * .79$ & rT & 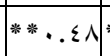 & $* * .09$ & 11 & $* * .7 \mathrm{~V}$ & $* *$ *.7 & 1. & 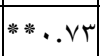 & $* * .79$ & $r$ \\
\hline$* . \vee \cdot$ & $\% * . \wedge 0$ & rV & $\div *$ *. $\div \leqslant$ & $* * . \vee \leqslant$ & 19 & **. . . I & $* * .09$ & 11 & $* \because .7 Y$ & ***.VI & $r$ \\
\hline$* .7 \mathrm{~V}$ & ***VY & YA & ** & **.VI & $r$. & $\because * 79$ & ***V & ir & $\because * \ldots$ \% & $* * \ldots \leqslant V$ & $\varepsilon$ \\
\hline$* * . V Y$ & $\% \div \cdot . \wedge 0$ & rq & $* * .7 Y$ & $\% *$ *.人1 & rI & $* * . r V$ & $* * \ldots \Lambda$ & Ir & $* * .7 r$ & $* * . V Y$ & 0 \\
\hline$* * . .7$. & $* * .71$ & $r$. & $\div * .0 \mathrm{~V}$ & $* * .00$ & rr & $* * .0 \mathrm{~V}$ & $* * .71$ & $1 \varepsilon$ & $* * .0 \mathrm{~V}$ & $* * .71$ & 7 \\
\hline$* * .77$ & " & M & $* * .04$ & $* * .71$ & Tr & $* * .0 \leqslant$ & $* * \cdot .11$ & 10 & $* * .01$ & $* *$ * . TV & v \\
\hline.$r o$ & $* * . . \leqslant Y$ & rr & $* * .7 V$ & $* * . V T$ & $r \varepsilon$ & $* * 0$. & $* * .09$ & 17 & $* * .71$ & $* * . \vee$ & $\wedge$ \\
\hline
\end{tabular}

يتضح من الجدول السابق أن عبارات جميع مجالات الاستمارة دالة

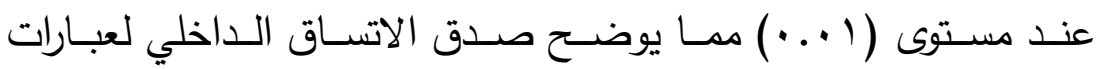

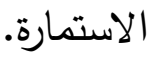

كمـا تم حسـاب معـاملات الارتبـاط بين المجـالات والدرجـة الكليـة للأداة، والجدول التالي يوضح هذه المعاملات: جدول (ץ) معاملات الارتباط بين المجالات واللارجة الكلية للاستمارة

\begin{tabular}{|c|c|}
\hline معامل الارتباط بالدرجة الكلية & 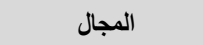 \\
\hline$* * . . \wedge 9$ & الموجهات الاجتماعية \\
\hline$* * .91$ & الموجهات الاقتصادية \\
\hline$* * . . \wedge 1$ & الموجهات التربوية \\
\hline$* * . . \wedge \mathrm{V}$ & الموجهات السياسية \\
\hline
\end{tabular}

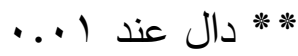


يتضـح من الجدول السابق أن المجالات الأربع تتسق مـع الاستمارة

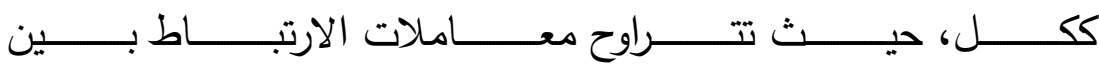
(Av) وجود اتساق بين جميع مجالات الاستمارة، وأنـه بوجهه عام صـادق في قياس ما وضع لقياسه. - صدق المقارنة الطرفية (الصدق التميزي) يقصد بالصدق التميزي قدرة الاستمارة على المقارنـة بين الفئة العليا

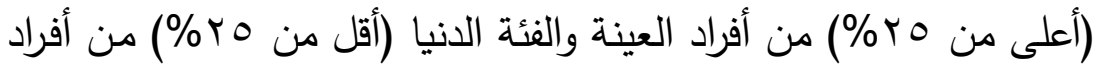

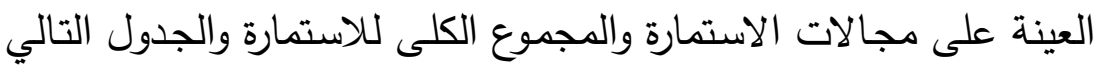
يوضتح هذه المقارنة:

جدول (ء) الصدق التميزي للاستمارة بين أفراد العينة في مجالات الاستمارة

\begin{tabular}{|c|c|c|c|c|c|c|}
\hline مستوى الدلالة & قيمة "ت & المعياري & الحسابي & العدد & المجموعة & المجال \\
\hline \multirow{2}{*}{ دالة عند مستوى } & \multirow[t]{2}{*}{ Ir.r } & r.\&1 & $11 . .0$ & Vi & الفئة الدنيا & \multirow{2}{*}{ الاجتماعية } \\
\hline & &.$\wedge$. & rtr.tu & VI & الفئة العليا & \\
\hline \multirow{2}{*}{ دالة عذ مستوى } & \multirow[t]{2}{*}{$|V . r|$} & r.l. & 14.0. & Vy & الفئة الدنيا & \multirow{2}{*}{ الاقتصادية } \\
\hline & & I.rY & rr..A & VI & الفئة العليا & \\
\hline \multirow{2}{*}{ دالة عند مستوى } & \multirow[t]{2}{*}{19.94} & r.\&v & $11.7 \mathrm{~V}$ & vi & الفئة الانيا & \multirow[t]{2}{*}{ الموجهات التربوية } \\
\hline & & ..$r v$ & rT.Aq & VI & الفئة العليا & \\
\hline \multirow{2}{*}{ دالة عند مستوى } & \multirow[t]{2}{*}{18.44} & $r . \& v$ & $18 . r 1$ & vi & الفئة الانيا & \multirow{2}{*}{ السياسية } \\
\hline & & . .9Y & $r+. \leqslant 9$ & V4 & الفئة العليا & \\
\hline \multirow{2}{*}{ دالة عند مستوى } & \multirow[t]{2}{*}{$11 . \varepsilon$} & $11 . r 9$ & $79.4 \%$ & vi & الفئة الانيا & \multirow[t]{2}{*}{ الدرجة الكلية } \\
\hline & & 1.vo & $94 . V 4$ & Vy & الفئة العليا & \\
\hline
\end{tabular}




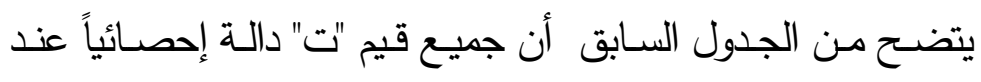
مستوى ا ...، مما يدلل على الصدق التميزي لمجالات الاستمارة والإستمارة ككل وهذا يؤكد صلاحيتها للتطبيق.

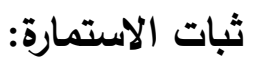

قام الباحث بحساب ثبات الاستمارة بطريقتين هما: طريقة ألفا

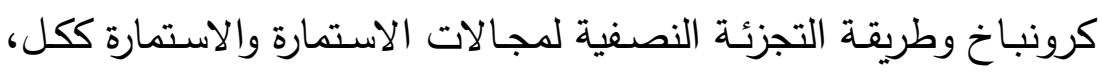
والجدول التالي يوضح معاملات الثبات: جدول (•) معاملات الثبات لمجالات الاستمارة والاستمارة ككل

\begin{tabular}{|c|c|c|}
\hline (التجزئة النصفية & معامل ألفا كرونباخ & المجال ل \\
\hline.$V Y$ & $\therefore$ vo & الموجهات الاجتماعية \\
\hline . . &. .14 & الموجهات الاقتصادية \\
\hline. .19 &..$\wedge r$ & الموجهات التربوية \\
\hline.$\wedge r$ &. .11 & الموجهات السياسية \\
\hline. $.9 r$ & .94 & الاستمارة ككل \\
\hline
\end{tabular}

يتضح من الجدول السابق أن جميع معاملات الثبات مرتفعة مما

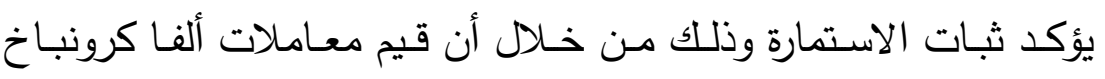

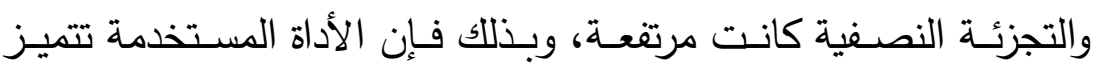
بالصدق والثبات ويمكن استخدامها علمياً. الأساليب الإحصائية المستخدمة:

تم استخدام الأساليب الإحصائية التي تتناسب مع طبيعة الدراسة

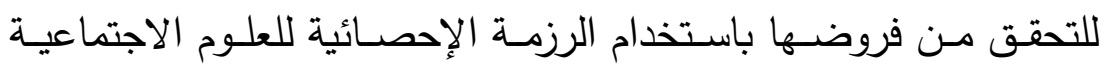
(SPSS)

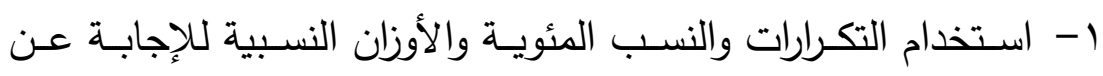
السؤال الأول للتعرف على الموجهات الدافعة نحو الترخيص لفروع جامعات دولية في المملكة العربية السعودية وللوصول إلى بيانات وصفية. 


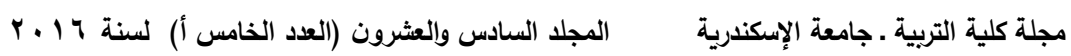

r- استخدام اختبار "ت" t-test لإجابة السؤال الثاني فيما يتعلق بكل من متغير النوع، ومتغير التخصص، ومتغير الجنسية. r- استخدام تحليـل التباين الأحـادي (One-Way ANOVA) لإجابـة ومئس السؤال الثاني المتعلق بمتغير الرتبة الأكاديمية. ع - استخدام معامل ألفا كرونباخ لحساب ثبات الاستمارة. 0- التجزئة النصفية لسبيرمان براون لحساب ثبات الاستمارة. צ- استخدام معامل الارتباط لبيرسون لحساب صدق الاتساق الداخلي. عرض نتائج الاراسة ومناقشتها نتائج السؤال الأول:

نص السئال على مـا يلي: مـا الموجهات الدافعـة نحو الترخيص لفروع جامعات عابرة للحدود في المملكة العربية السعودية من وجهة نظر اعضاء هيئة التدريس بجامعة الدمام ؟ جماع

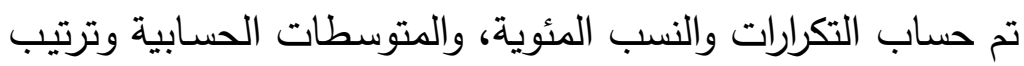
العبارات لاستجابات العينة ككل فى كل محور من المحاور الأربعة على ولى

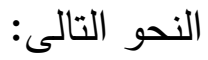

\section{- الموجهات الاجتماعية - - الماتية}

جدول (ا) التكرارات والنسب المئوية والمتوسط الحسابي فى محور الموجهات الاجتماعية

\begin{tabular}{|c|c|c|c|c|c|c|c|c|c|c|c|}
\hline \multirow{2}{*}{ | المستوى } & \multirow{2}{*}{ الترتيب } & \multirow{2}{*}{ الانحراف } & \multirow{2}{*}{ |الحسابى } & \multicolumn{2}{|c|}{ موافق } & \multicolumn{2}{|c|}{ موافق إلى حد ما } & \multicolumn{2}{|c|}{ غير موافق } & \multirow{2}{*}{\begin{tabular}{|c|} 
الاستجابات \\
العبارة \\
\end{tabular}} & \multirow[t]{2}{*}{ م } \\
\hline & & & & $\%$ & $ت$ & $\%$ & ت & $\%$ & ت & & \\
\hline مرتفع & $v$ &. $.7 \mathrm{~V}$ & Y.OY & Tr.r. & 19. & PV.AV & 10 & $9 . \wedge \varepsilon$ & r. & | & 1 \\
\hline مرتفع & $\varepsilon$ &. .04 & r.VI & $V V . .0$ & rro & IV.rA & or & $0.0 \mathrm{~V}$ & iv & |تقديم خدمات & r \\
\hline
\end{tabular}




\begin{tabular}{|c|c|c|c|c|c|c|c|c|c|c|}
\hline & & & & & & & & & & إلمجتمع. \\
\hline مرتفع & $r$ & ד4 & r.va & N1.T) & $r \leqslant \Lambda$ & 19.49 & 0. & T.r. & v & |لاجلى التمليمي \\
\hline متوسط & $\wedge$ &.$\cdot v 1$ & r.rA & O..AY & 100 & r... & 11. & $\mid 1+11$ & 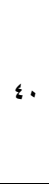 & | زلوافينين وتنوع \\
\hline مرتفع & $r$ & . . & T.VY & V५. . & TrT & $19.7 \mathrm{~V}$ & 7 & r.94 & Ir & | التمية مهارات \\
\hline مرتفع & 0 &. $.0 \mathrm{~V}$ & r.79 & $V \leqslant . V_{0}$ & TYA & $19.7 \mathrm{~V}$ & 7 & $0.0 \mathrm{~V}$ & iv & |الاجتماعية حوكة \\
\hline مرتفع & 7 & . . & Y.TI & TV.TY & r.o & שז.צי & A. & 1.04 & $r$. & 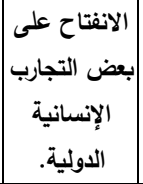 \\
\hline مرتفع & 1 & $\therefore \leqslant 0$ & r.AI & הז.T. & roo & $1 \leqslant .1$. & $\varepsilon r$ & T.T. & $\mathrm{v}$ & | تقليميم خدمة \\
\hline مرتفع & & ort. & r.T4 & & & & & & & |المحور ككل | \\
\hline
\end{tabular}

يـرى أعضـاء هيئة التـدريس الموجهـات الاجتماعيـة بشكل عـام بمسـتوى مرتفع، إذ بلـن المتوسط الحسـابى لمجموع هذه الموجهات ككل (T. (Y) و هـو مسـتوى مرتفـع، حيـث اشـتملت على ^ موجهات تراوحـ

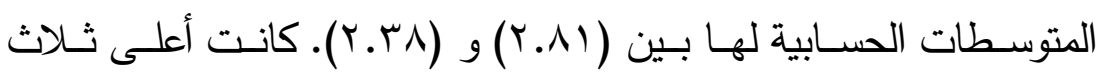
عبارات ضمن هذا المستوى: العبارة رقم (^) "رغبة فئات المجتمع في تقديم

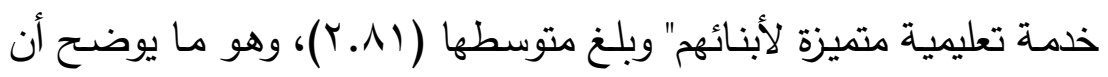
الهدف لـيس التعليم للجميع فقط ولكنـه يتعدى ذلك إلى التعليم المتميز للجميع في ظل ثورة المعرفة فمن خلالها يكون التطوير وتقديم خدمات 
تعليمية متميزة تتمثل في إعداد مخرجات مؤهلة والريادة في تقديم الخدمات ضمن بيئة عمل تتافسية تطهح إلى الارتقاء بمستوى الخدمات التعليمية.

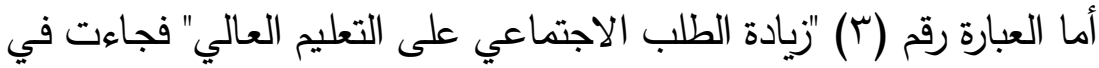
المرتبة الثانية وكان متوسطها (Y9.V9). وقد يرجع ذللك إلى تلبية الاحتياج المتزايد على التعليم بسبب الزيادات المضطردة في أعداد السكان وازدياد الوعي الاجتماعي بدور التعليم وأهميته في الحراك الاجتماعي. فالعبارة

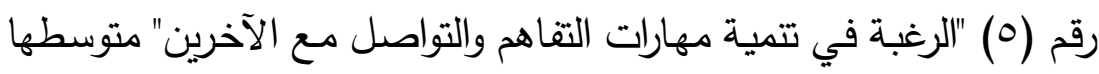

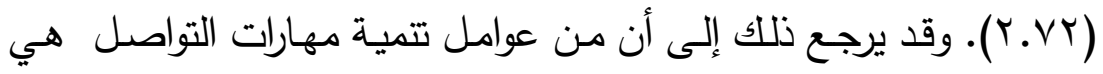

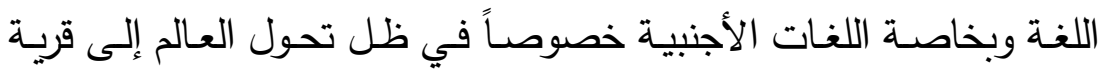

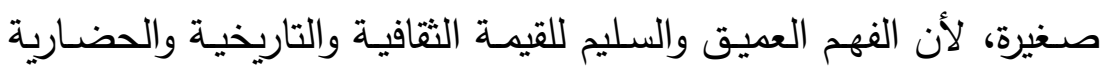
للغة ستساعد بشكل أكبر على التقارب بين الشعوب وبالتالي العمل على ولى ردم الهـوة الثقافيـة بـين الحضـارات وتجـاوز سـوء التفـاهم وبنـاء جسـور الاحترام المتبادل بين المجتمعات. وهذا ما أشارت إليه دراسة الكيرعاني

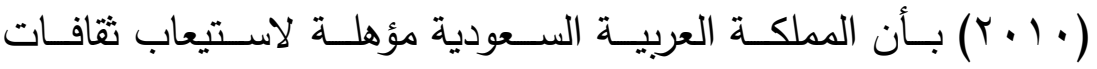
أخرى.خصوصاً وأن افتتاح فروع للجامعات الدولية سيخلق ثقافة متعددة الأبعاد تتجاوز الأفراد لتطال المجتمع في المملكة العربية السعودية. فى حين كانت أدنى ثلاث عبارات ضشمن هذا المستوى: العبارة رقم (ع) "زيـادة عدد المقيمين الوافدين وتتـوع جنسياتهر" وكـان متوسطها

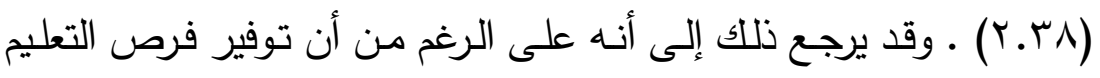
العالي لأبناء المقيمين الوافدين في المملكة العربية السعودية يحقق الاستقرار

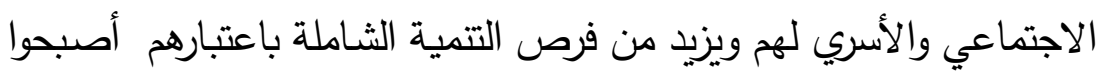
جزء من العملية الإنتاجية نظراً لتتوع جنسيات الوافدين كما أن بعض ولن أبناءهم

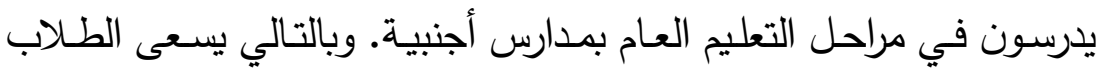

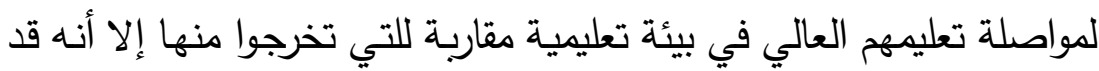

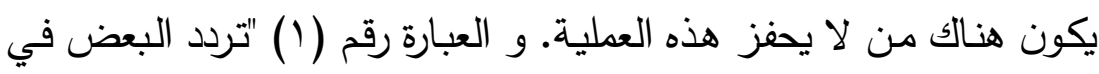




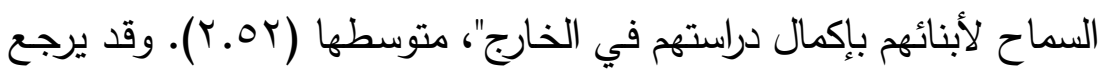

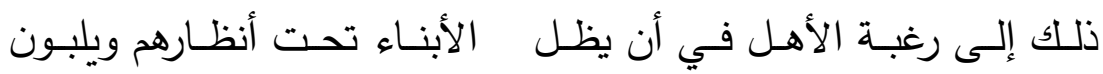

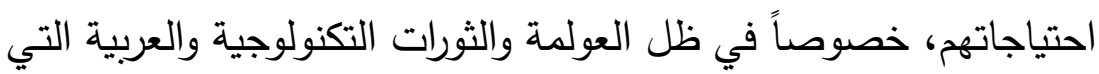

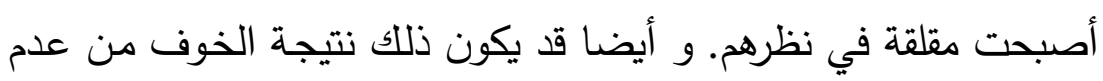
انسجام الابن مـع البيئات المختلفة، إذا فكّر بالدراسـة في الخارج. والعبارة

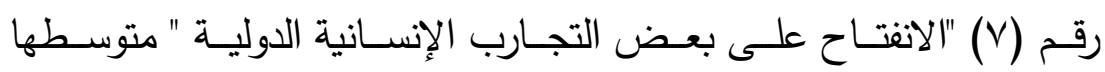

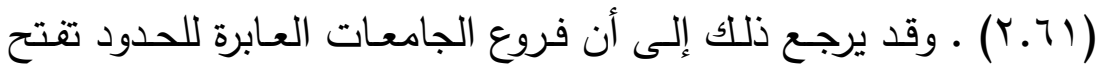

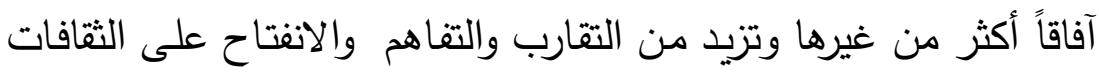

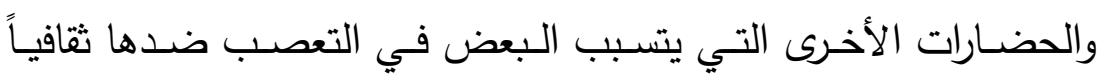

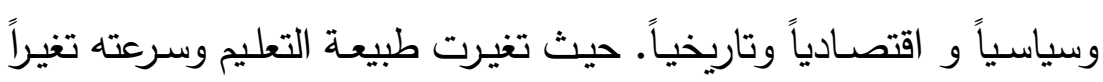

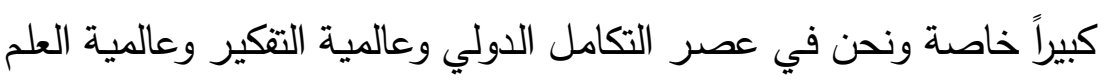

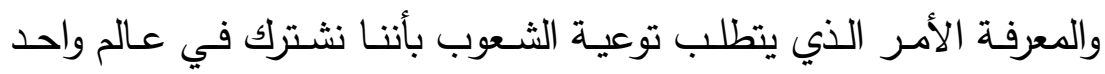

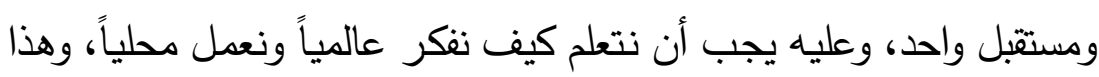
يؤكد حاجة العالم اليوم للمواطن العالمي. وتتفق هذه النتيجة مـع نتائج دراسة

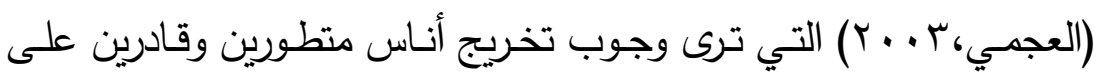

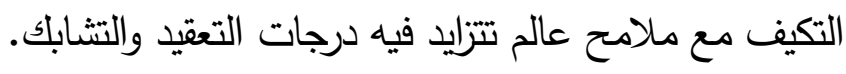

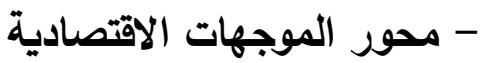

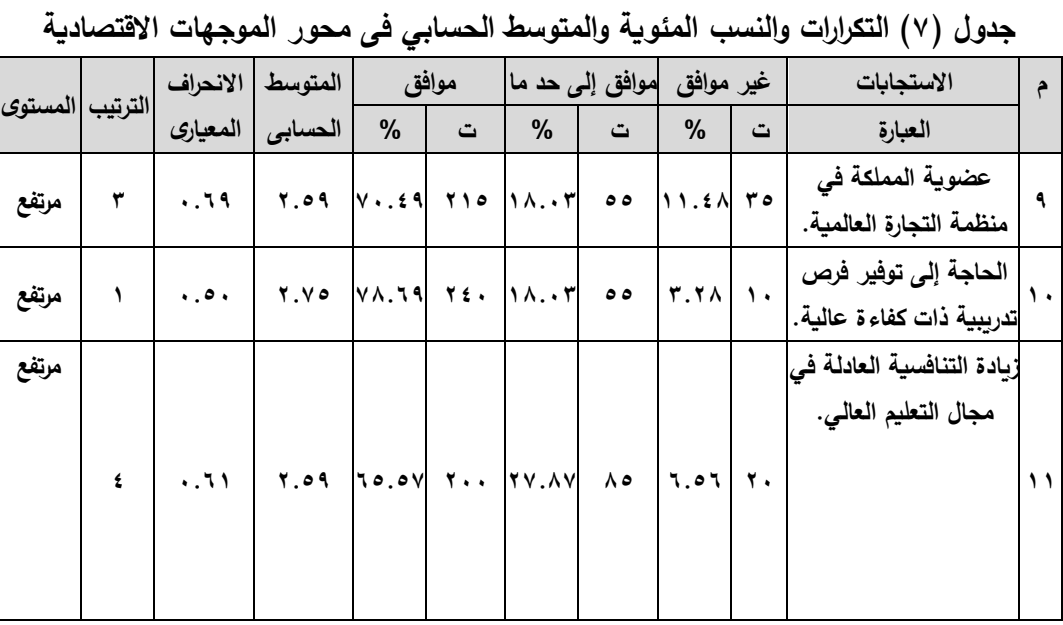




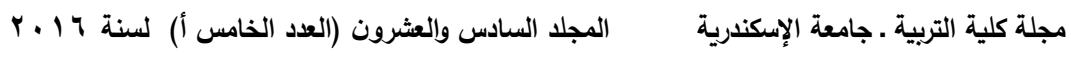

\begin{tabular}{|c|c|c|c|c|c|c|c|c|c|c|c|}
\hline \multirow{2}{*}{ |المستوى | } & \multirow{2}{*}{ الترتيب } & \multirow{2}{*}{ المعيارى } & \multirow{2}{*}{ الصسابى } & \multicolumn{2}{|c|}{ موافق } & \multicolumn{2}{|c|}{ موافق إلى حد ما } & \multicolumn{2}{|c|}{ غير موافق } & \multirow{2}{*}{$\begin{array}{l}\text { الاستجابات } \\
\text { العبارة }\end{array}$} & \multirow[t]{2}{*}{ s } \\
\hline & & & & $\%$ & ت & $\%$ & ت & $\%$ & $ت$ & & \\
\hline مرتفع & 0 & 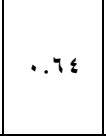 & r.०६ & |rr.t. & 19. & r9.01 & 9. & A.r. & ro & الالتيتمار في مجال التمعي بأهمية & ir \\
\hline متوسط & $\wedge$ & .rvi & r.11 & $m 4 . . v$ & 11. & $\leqslant 0.9$. & $1 \leqslant$. & $1 \wedge . . r$ & $\infty$ & |نتشار ثقافة الدفع مقابل & $1 \%$ \\
\hline مرتفع & v & $\therefore v$. & r.MY & $\{9.11$ & 10. & rv.v. & 110 & $|1+.1|$ & 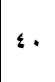 & تخفيف العبء عن ميزانية & $1:$ \\
\hline مرتفع & r & $\cdots 7$ & r. & $v 0 \leqslant q$ & Ylo & rr.90| & v. & 7.04 & $r$. & 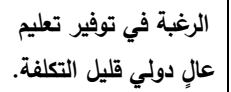 & 10 \\
\hline مرتفع & 1 & 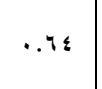 & r. $\leqslant 9$ & OO.re & ivo & 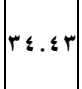 & 1.0 & A.r. & ro & |مواجهة التغير المستقبلي & 17 \\
\hline مرتفع & & $\ldots \varepsilon$ & r.or & & & & & & & الدحور ككل & \\
\hline
\end{tabular}

يـرى أعضـاء هيئـة التـدريس الموجهـات الاقتصـادية بشـكل عـام

بمسـتوى مرتفـع، إذ بلـن المتوسـط الحسـابى لمجمـوع هذه الموجهات ككل (Y.OY) و هـ مسـتوى مرتفـع، حيـث اشـتملت على ^ موجهات تراوحت

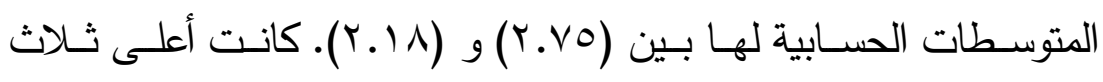
عبارات ضـمن هذا المستوى: العبارة رقم ( • () "الحاجـة إلى توفير فرص

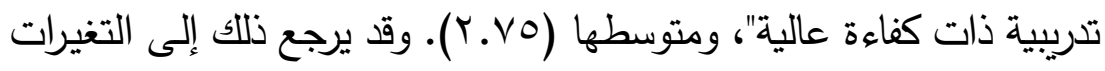
المعرفيـة والعلميـة والتقنيـة المتسـارعة إضـافة إلىى أن نوعيـة التدريب تغيرت مـع تغير سـوق العمل العالميـة بفضـل القيمـة المضـافة لإنتاجيـة

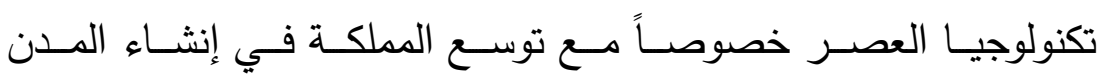
الاقتصـادية الأمـر الـي يتطلب إيجـاد مهـارات مسـتحدثة تواكب تلك لك التطورات وبخاصـة الصناعية منها، وهذا ما أشـارت إليه دراسـة ويلكنس (Wilkins,2011). فالعبارة رقم (0 1 ) "الرغبـة في توفير تعليم عـالٍ دولي

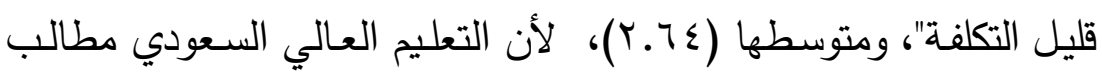


بالبحث عن شركاء للإسهام معه في حل الاختناقات الكبرى التي يواجها

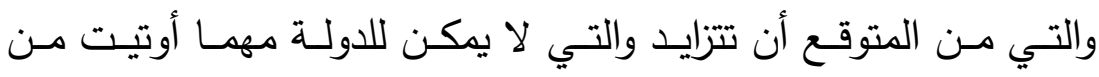
إمكانات أن تتجاوب معها بشكل فاعل خصوصـاً الاحتياجات المتزايدة

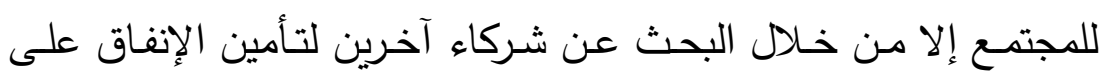

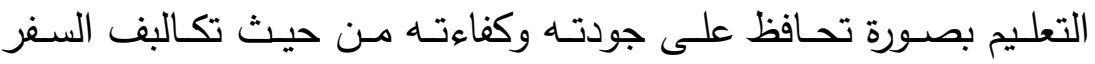
والإقامة وغيرها. والترخيص لفروع جامعات دولية هي إحدى بدائل التعليم

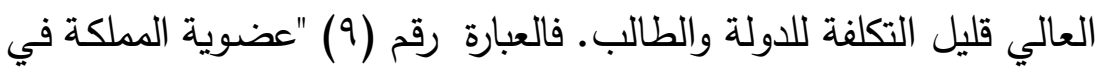
منظمة التجارة العالمية" متوسطها (ب9.09). والانضمام إلى منظمة التجارة

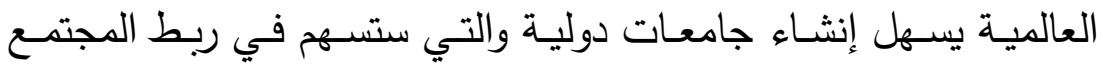
السـودي بالتكنولوجيـا الأجنبيـة وإتاحـة الفرصـة للقوى المحليـة الوطنيـة ولية

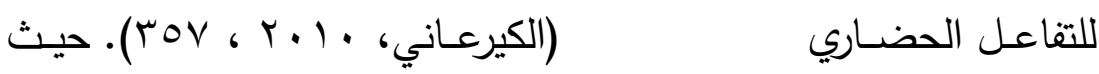
أسهمت اتفاقية (الجات) في تحرير التعليم العالي العابر للحدود فتحول من

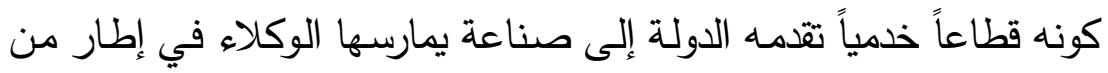

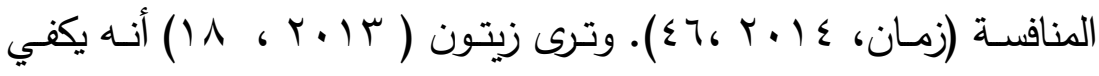
الدولة عضويتها في منظمة التجارة العالمية والتزامها بالمبادئ العامة لاتفاقية

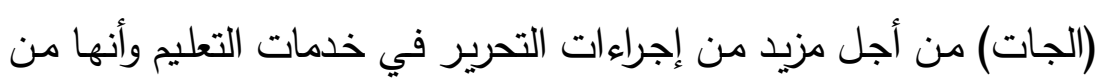
العوامل التي أسـهمت في الدفع نحو الانفتاح على خدمات التعليم العـالي

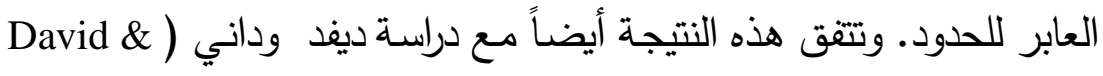

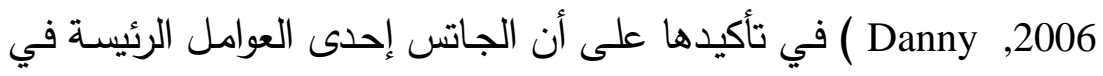
زيادة نمو التعليم العالي العابر للحدود. فى حين كانت أدنى ثلاث عبارات ضمن هذا المستوى: العبارة رقم

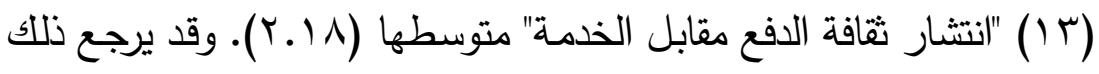

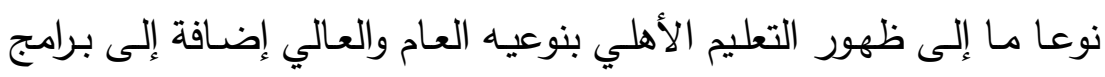

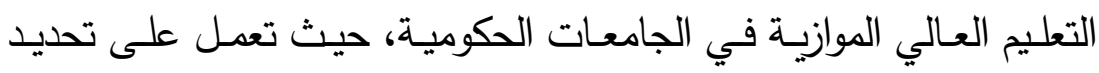

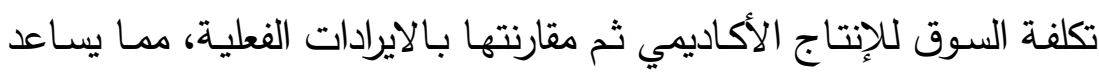


على تحديد سعر الخدمة الأكاديمية. والعبارة رقم (ع ( ) "تخفيف العبء عن

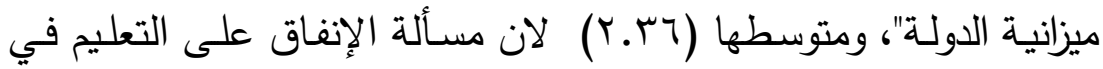

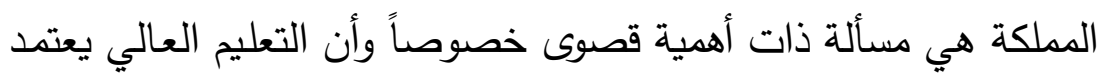
على مصدر تمويل واحد وهو الدولة، حيث ينبغي تتويع مصادر التمويل. وهذه البرامج ربما تجذب أكبر قدر من الاستثمارات في التعليم كما حدث في تئي

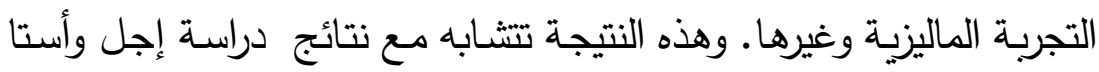

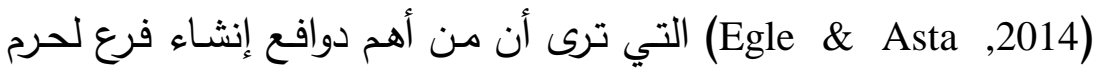

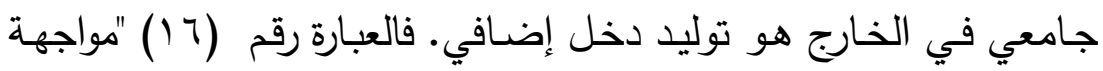

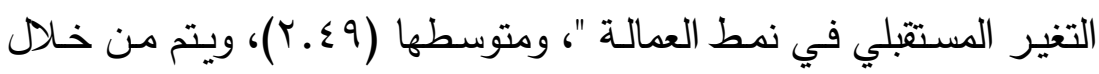
إسهامها في توفير البرامج المهنية التي يحتاجها سوق العمل، خصوصاً وأن

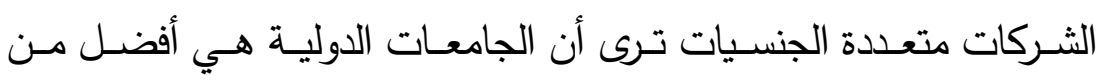

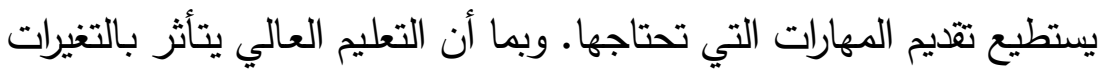
في عالم العمل ينبغي أن يسهم في تثكيل عالم العمل المستقبلي، خصوصاً الوظائف التي أوجدها نظام الانفتاح الاقتصادي.

\section{- محور الموجهات التربوية}

جدول (^) التكرارات والنسب المئوية والمتوسط الحسابي فحى محور الموجهات التربوية

\begin{tabular}{|c|c|c|c|c|c|c|c|c|c|c|c|}
\hline \multirow[t]{2}{*}{ المستوى } & \multirow[t]{2}{*}{ الترتيب } & \multirow{2}{*}{ | الانحراف| } & \multirow{2}{*}{ الحسابى المتوسط } & \multicolumn{2}{|c|}{ موافق } & \multicolumn{2}{|c|}{ موافق إلى حـ } & \multicolumn{2}{|c|}{ غير موافق } & \multirow{2}{*}{ الاستجابات } & \\
\hline & & & & $\%$ & ت & $\%$ & ت & $\%$ & $ت$ & & \\
\hline مرتفع & $r$ & ז.0. & r.vV & $11.9 \mathrm{~V}$ & ro. & 17.11 & $\varepsilon$ & ؛.95 & 10 & |منح درجات علمية تحظى عائمي. & \\
\hline | مرتفع & $\wedge$ & $.7 \varepsilon$ & r.o & Tr.r. & 19. & r9.01 & 9. & A.r. & ro & البعات التعلى ترشيد & \\
\hline مرتفع & v & .10 & T.T\& & VT.VV & rro & 17.49 & 0. & $9 . \wedge \varepsilon$ & $r$. & محاولة القضاء على الثهادات الوهمية & \\
\hline |مرتفع & $\varepsilon$ &. .0 . & r.vo & VA.79 & $r \leqslant 0$ & $\mid A . . r$ & 00 & r.rA & 1. & |الالتحاجة إلى توسيع فرص التعالي & \\
\hline مرتفع & 1 &..$\leqslant \wedge$ & r.va & $11.9 \mathrm{~V}$ & ro. & $1 \leq . v_{0}$ & $\leq 0$ & r.rA & 1. & السعي لإثراء البحث & \\
\hline
\end{tabular}




\begin{tabular}{|c|c|c|c|c|c|c|c|c|c|c|c|}
\hline \multirow[t]{2}{*}{ |المستوى| } & \multirow[t]{2}{*}{ الترتيب } & \multirow{2}{*}{ المعيارى } & \multirow{2}{*}{ |الحسابى |- المتط } & \multicolumn{2}{|c|}{ موافق } & \multicolumn{2}{|c|}{ موافق إلى حد } & \multicolumn{2}{|c|}{ غير موافق } & \multirow{2}{*}{ الاستجابات } & \multirow[t]{2}{*}{ P } \\
\hline & & & & $\%$ & ت & $\%$ & $ت$ & $\%$ & ت & & \\
\hline & & & & & & & & & & العلمي وتطويره. & \\
\hline مرتفع & r & $\therefore \leqslant 0$ & r.v9 & $|A, . \mu T|$ & $r \leqslant 0$ & IA..r & 00 & $1.7 \varepsilon$ & - & تخصصات علمية بينية & $r$ \\
\hline مرتفغ & 1 & $\therefore \varepsilon \wedge$ & r.VY & $\mathrm{Vr} . \mathrm{vV}$ & rro & $r \leqslant .09$ & $v_{0}$ & $1.7 \leqslant$ & - & للكثير من الجامعات العية الجيدة & $r T$ \\
\hline مرتفع & - & .. & r.vo & V^.79 & $r \leq \cdot$ & IA..r & 00 & T.YA & 1. & الوالأنبة من تعلم تلكين أبناء & $r \leqslant$ \\
\hline مرتفع & &. .44 & r.VY & & & & & & & المحور ككل & \\
\hline
\end{tabular}

يرى أعضاء هيئة التدريس الموجهات التربوية بشكل عام بمستوى مرتقع،

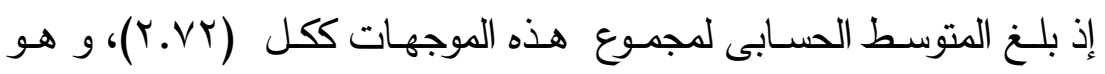
مستوى مرتقع، حيث اشتملت على 1 موجهات تراوحت المتوسطات الحسابية

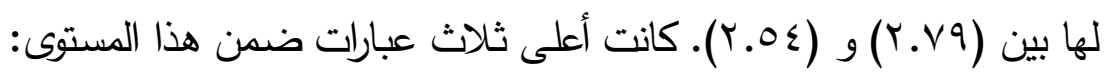

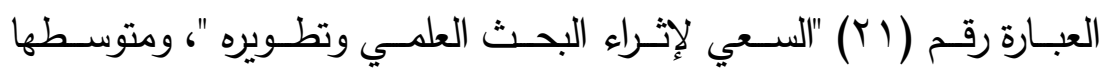

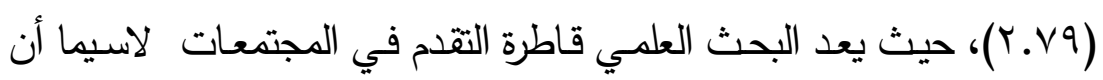
الكثير من الجامعات الدولية لليها خبرة كبيرة في مجال البحث العلدي وآلياته

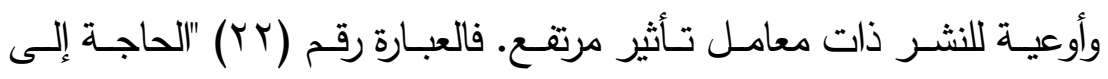

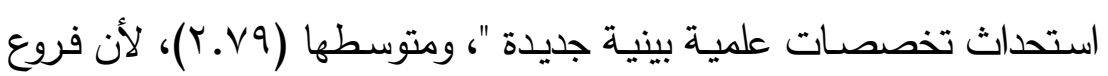

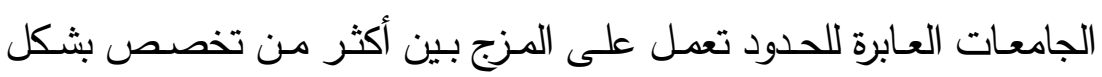

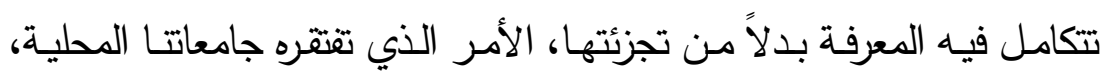

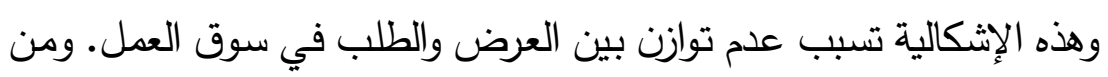

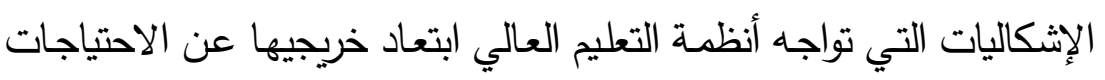

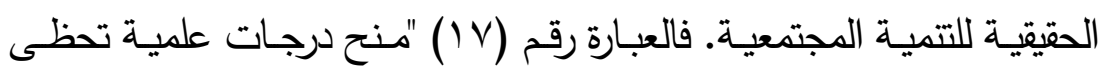
باعتراف عالمي"، ومتوسطها (Y.VV). من خلال التزامها بالمعايير الأكاديمية 
ومتطلبات ضمان الجودة سواء في دول مقراتها الرئيسـة أو الدول الحاضنـة

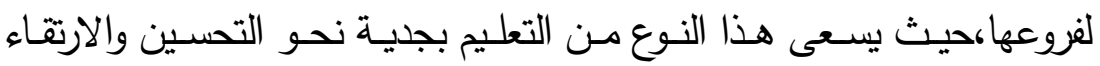

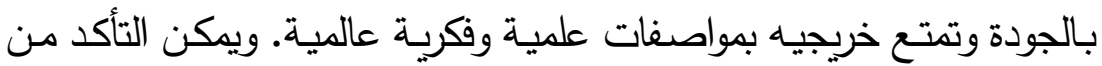
ذللك مـن خـلال تشكيل لجنـة دوليـة لضـمان جودة فروع الجامعـات الدوليـة بالمملكة العربية السعودية مهنها التأكد من أن البرامج الأكاديمية التي توفرها الفروع هي بالجودة نفسها التي تقدمها جامعاتها الأم. لبه فى حين كانت أدنى ثناث عبارات ضمن هذا المستوى: العبارة رقم

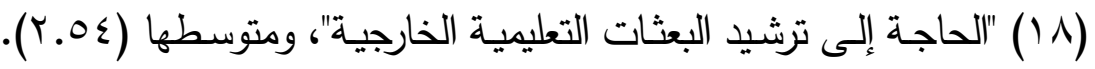

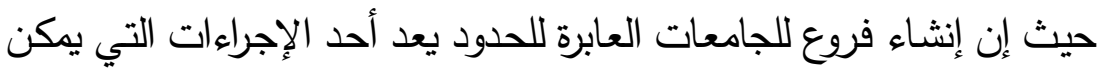

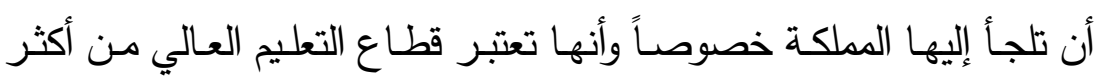

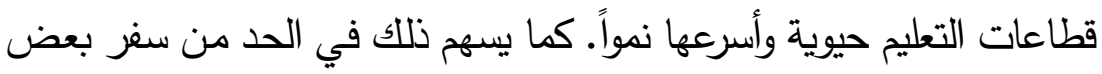

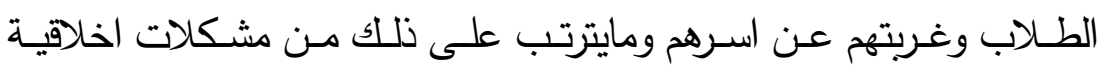
واجتماعية قد لاتتقق مع تقاليد وعادات المجتمع السعودي، بالإضافة إلى الحد

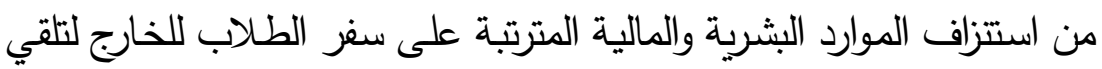
العلم. والعبارة رقم (9 (1) "محاولة القضـاء على الثـهادات الوهية والواهنة"،

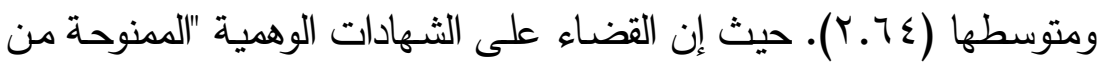
جامعـة لا تعترف بها دولة المقر" والواهنـة "وهي تلك الثـهادة الممنوحة من جامعة لا تتطبق عليها المعايير العلمية والتعليمية السارية في المملكة العربية

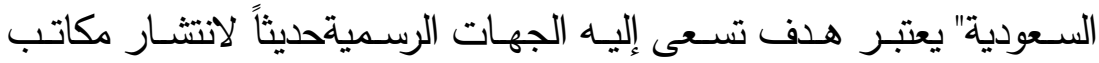
لمؤسسات تعليمية بمسميات أجنبية وعربية دولية في المملكة تمنح الراغبين في المؤهلات العليا مايريدون نظير مقابل مـادي دون إذن رسمي لممارسـة

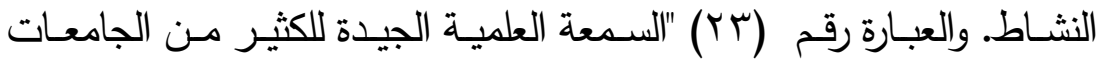
الدولية"، ومتوسطها (Y.VY. (Y. أن الكثير منها لها تاريخ عريق في التعليم العالي قد يصل إلى مئات السنين ولها في بلدانها سمعة بين الجامعات، ولخريجيها بريق أكثر وفرصـة عمل أكثر في أحيان أخرى.كمـا يمكن مـن لن 
خـلال الجامعـات العـابرة للحدود الارتقاء بمستوى والسـعة الدوليـة للجامعات المحلية وذلك من خلال المحافظة على مستوى المنافسة الدولية.

\section{- محور الموجهات السياسية}

جدول (9) التكرارات والنسب المئوية والمتوسط الحسابي فى محور الموجهات السياسية

\begin{tabular}{|c|c|c|c|c|c|c|c|c|c|c|c|}
\hline \multirow[t]{2}{*}{ المستوى } & \multirow{2}{*}{ | الترتيب } & \multirow{2}{*}{ الانحراف } & \multirow{2}{*}{ |لكسابح|| } & \multicolumn{2}{|c|}{ موافق } & \multicolumn{2}{|c|}{ موافق إلى حد } & \multicolumn{2}{|c|}{ غير موافق } & \multirow{2}{*}{ الاستجابات } & \multirow[t]{2}{*}{ p } \\
\hline & & & & $\%$ & ت & $\%$ & $ت$ & $\%$ & $ت$ & & \\
\hline مرتفع & v &..$\vee 4$ & r. $\leqslant \leqslant$ & 7.74 & 110 & rr.qo & v. & 17.49 & o. & 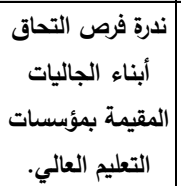 & ro \\
\hline مرتفع & r &. .04 & r.79 & Vr.vV & rYO & M.MI & 90 & $\varepsilon .9 r$ & 10 & لمواجهة تحليات الرغبة في تهيئة & rT \\
\hline مرتفع & 7 &. .79 & $r . \leqslant q$ & $7 . .74$ & 110 & rV.Av & 10 & $11 . \leqslant \wedge$ & ro & |لالعاتبال دورا مهما السياسية فيمية إلى توفير & rV \\
\hline مرتفع & $\bullet$ &. $.7 V$ & Y.० & (r.q4 & 190 & rצ.rT & $\wedge$. & $9 . \wedge \leq$ & $r$. & |الخلافات التاريخية & rs \\
\hline مرتفع & $r$ & $.7 \leq$ & r.०9 & TV.YI & r.O & $r \leqslant .09$ & vo & A.r. & ro & الرغبة في تعزيز & rq \\
\hline
\end{tabular}

rA. 


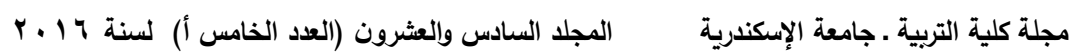

\begin{tabular}{|c|c|c|c|c|c|c|c|c|c|c|c|}
\hline \multirow[t]{2}{*}{ المستوى } & \multirow{2}{*}{ |الترتيب } & \multirow{2}{*}{ المعيارى } & \multirow{2}{*}{ |لكسابى| } & \multicolumn{2}{|c|}{ موافق } & \multicolumn{2}{|c|}{ موافق إلى حد } & \multicolumn{2}{|c|}{ غير موافق } & \multirow{2}{*}{ الاستجابات } & \multirow[t]{2}{*}{ p } \\
\hline & & & & $\%$ & ت & $\%$ & $ت$ & $\%$ & $ت$ & & \\
\hline & & & & & & & & & & الثلقافة السياسية. & \\
\hline مرتفع & $\varepsilon$ & . IV & r.07 & $10.0 \mathrm{~V}$ & $r .$. & $r \& .09$ & $v_{0}$ & $9 . \wedge \varepsilon$ & $r$. & مدخل التحقيق & $r$. \\
\hline مرتفع & $\wedge$ & $\therefore \vee 9$ & T.TE & 0 \&.1. & 190 & TM.rT & A. & $19.7 \mathrm{~V}$ & 7. & تكوين نخب بأهمية & r \\
\hline مرتغع & 1 & . . & r.vv & VA.79 & $r \leqslant$. & $19.4 \mathrm{~V}$ & $r$ & $1.7 \varepsilon$ & 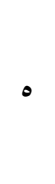 & كمانة الملكة اللتعيم & Tr \\
\hline مرتفع & & . . \& & r.os & & & & & & & المحور ككل & \\
\hline
\end{tabular}

يـرى أعضـاء هيئسة التـدريس الموجهات السياسـية بشكل عـام

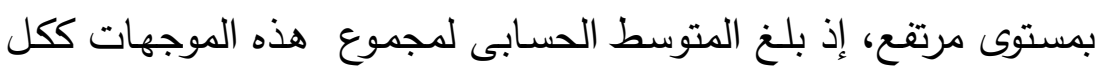

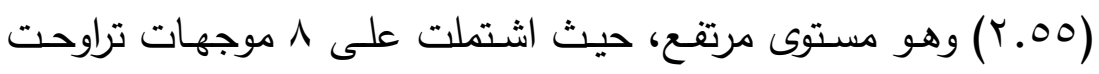

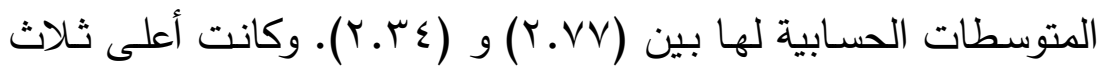

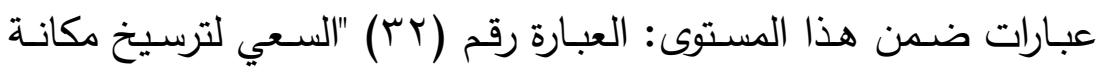

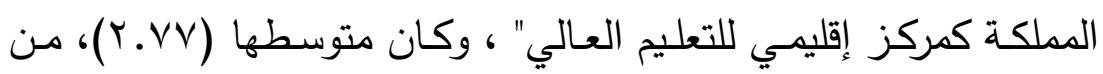
خلال نمو هذا القطاع باستمرار وزيادة عدد الطلاب الملتحقين والتوسع في مئي

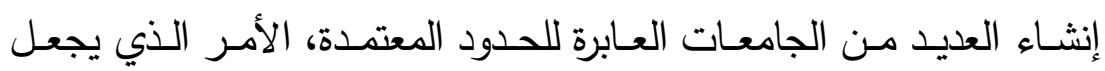

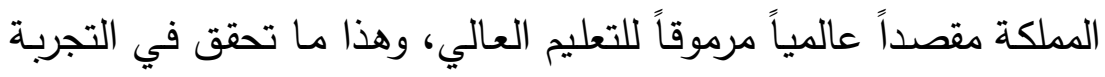
الإماراتية التي يوجد بها قريـة المعرفة التي تضم معظم فروع الجامعات

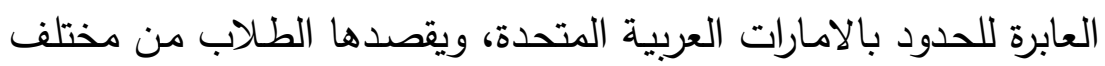

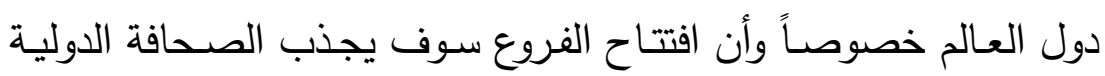
ومن ثم تسليطها الضوو على المناشط المتنوعة لتلك المؤسسـات سواء كانت تعليمية أم غير تعليمية. فالعبارة رقم (T (Y) "الرغبة في تهيئة المواطن

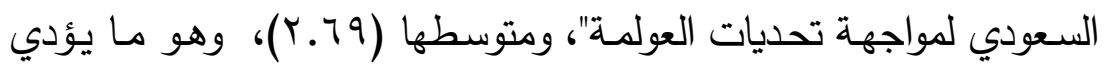

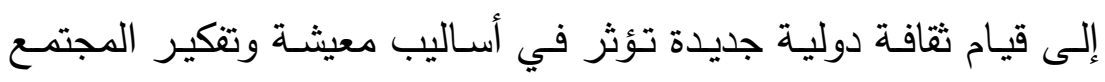


السعودي المعاصر ، لأنه - في ظل العولمـة - لم تعد أهداف مؤسسات

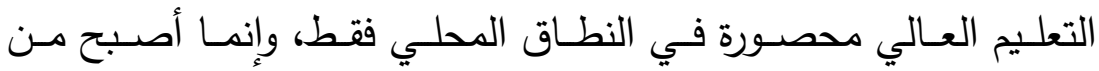
المفترض أن نجاح هذه المؤسسات يتوقف أيضـا على مدى استجابتها للتحديات التي تواجه المواطنين، الأمر الذي يجعل من فروع الجامعات

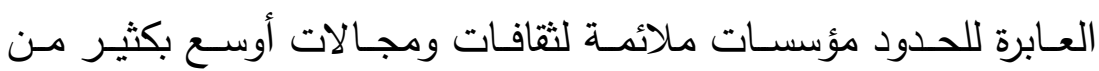

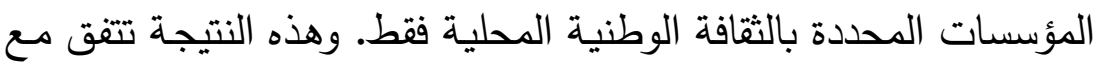

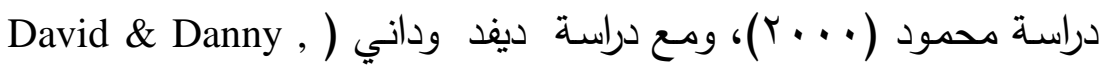
2006 ) في تأكيدهما على أن العولمة من مبررات تدويل التعليم العالي.

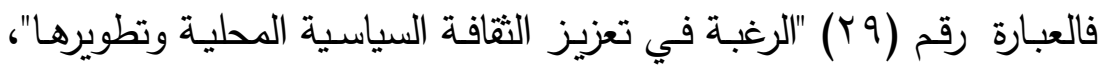

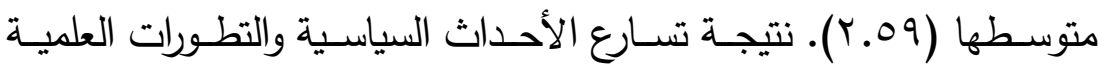
والتقنيـة والثقافيـة على الصـعيد العـالمي وبـروز مفـاهيم وصـيخ سياسـية مستحدثة تختلف تفسيراتها ودلالاتها حسب مصادر الخطاب وتوجهاته مثل الديموقراطية وحقوق الإنسان وثقافة السلام والمجتمع المدني .. إلخ (السنبل، $(r \leq 6) \leqslant r \leqslant$

في حين كانت أدنى ثلاث عبارات ضمن هذا المستوى: العبارة

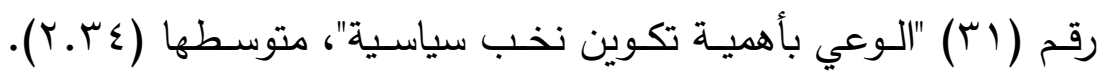
ولعل هذا يؤكد أن تكوين وتثكيل النخب السياسية يعتمد على معرفة الآخر وخصائصسه لكي يتعامل معه في ظل التحالفات والتكتلات، وهذا

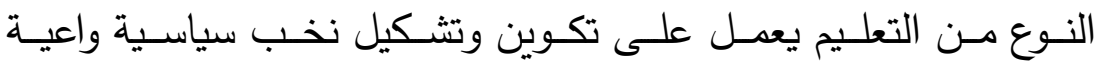

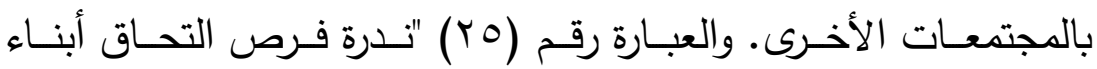
الجاليات المقيمة بمؤسسات التعليم العالي"، متوسطها (ع ــ؟). حيث إن التوسـع في المشـاريح الإنمائيـة والتطويريـة في المملكـة - بسـبب زيـادة

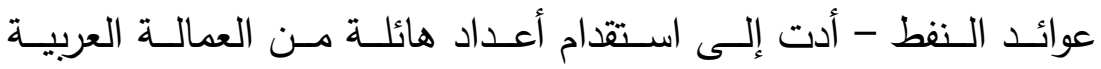
والأجنبية، ونسبة كبيرة من هذه العمالة الوافدة استقدموا عوائلهم وأبناءهم.

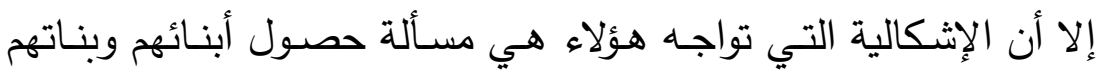


على مقاعـد في التعليم الجـامعي، إذ أن قبـول غيـر السـوديين في

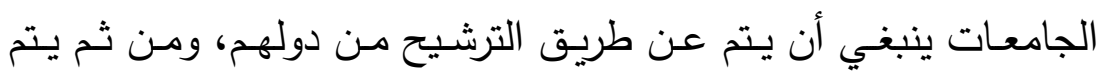

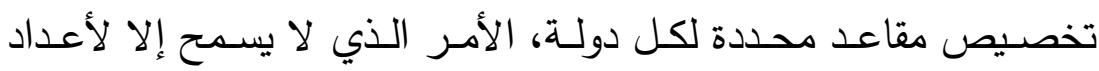

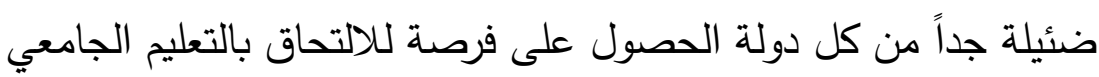

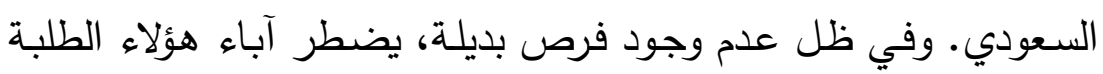

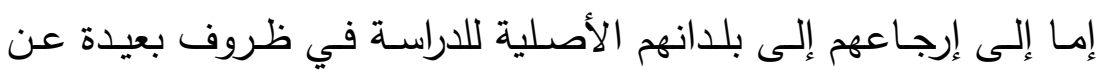
الأسرة، أو ابتعـاثهم إلى الخـارج وبذل أمسوال طائلـة في سبيل تعليمهر.

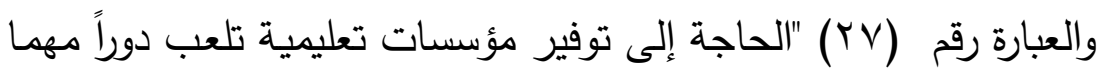

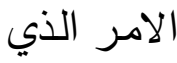
في الاتصال السياسي "، متوسطها (9 (ب. ب). يحتم إعادة النظر في الرؤى والفلسفات الموجهة لأهداف التربية والتعليم

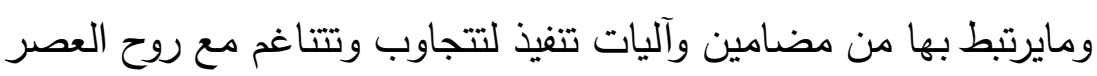
ومعطياته.

ويمكن ترتيب هذه الموجهات الأربعـة على النحـو الذي يوضـحه

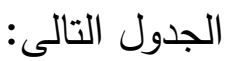
جدول ( • 1) المتوسطات الحسابية للمحاور بشكل عام

\begin{tabular}{|c|c|c|c|}
\hline الترتيب & الانحراف المعيارى & الحستوسط & المحوز \\
\hline$r$ & . . r & r.Y & الموجهات الاجتماعية \\
\hline$\varepsilon$ & $\cdot \varepsilon$ & r.or & الموجهات الاقتصادية \\
\hline 1 & ע4 & r.vr & الموجهات التربوية \\
\hline$r$ & . . $\leqslant \leq$ & r.00 & الموجهات السياسية \\
\hline
\end{tabular}

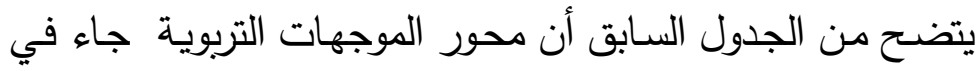

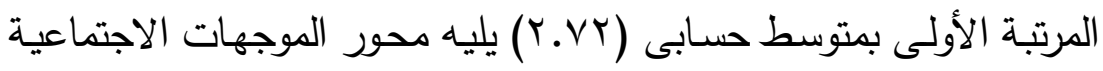

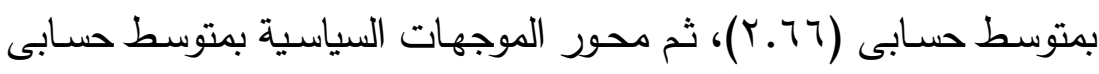

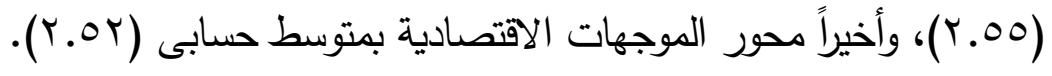


ولعل هذا يعطينـا مؤشـراً إلى أي مدى يهتم المجتمع بالتربيـة

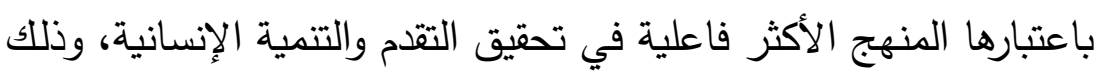

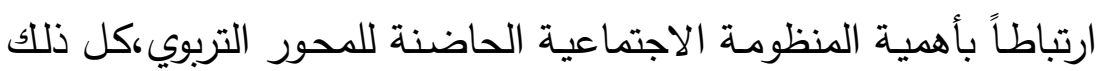

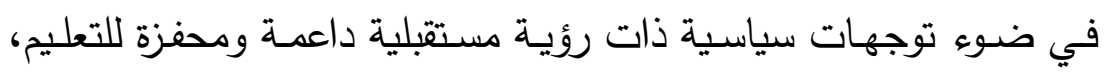

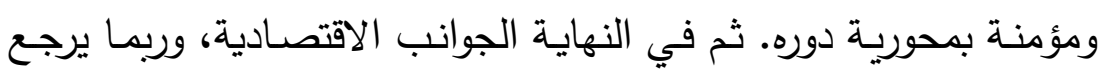
ذلك إلى مرجعية النسق القيمي المجتمعي الذي يرى أن الاقتصاد وسيلة وليس غاية في ذاته. نتائج السؤال الثاني:

نص السؤال على ما يلي: إلى اي مدى توجد فروق ذات دلالة

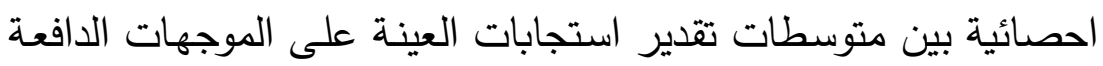

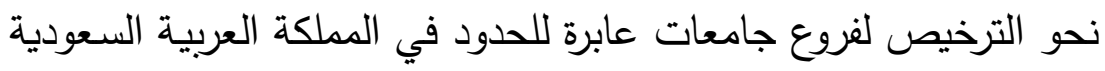
تعزى لمتغيرات: النوع، التخصص، الجنسية، الرتبة الأكاديمية؟

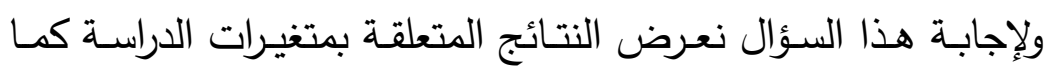

\section{- - متغير النوع: -}

تم حساب المتوسطات الحسابية والانحرافات المعيارية لكل مجال من

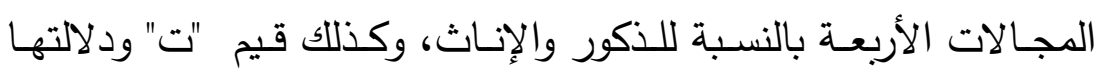
الإحصائية، ويمكن عرض ما توصل إليه الباحث من نتائج على النحو ولآنه بالنيه

جدول (1 1) يوضح الأعاد والمتوسطات والانحرافات المعيارية وقيمة "ت" ودلالتها في مجالات

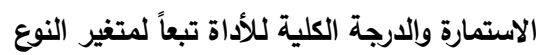

\begin{tabular}{|c|c|c|c|c|c|c|}
\hline مستوى الدلالة & ت & $\varepsilon$ & b & ن & النوع & المجال ل \\
\hline \multirow{2}{*}{ غير دالة } & \multirow{2}{*}{$\ldots r$} & r.19 & YI.Y & $|v|$ & ذكور & \multirow{2}{*}{ الموجهات الاجتماعية } \\
\hline & & r.rq & ri.ro & (r) & إناث & \\
\hline \multirow{2}{*}{ غير دالة } & \multirow{2}{*}{..+9} & r.VY & $r . . r r$ & ivi & ذكور & \multirow[t]{2}{*}{ الموجهات الاقتصادية } \\
\hline & & זד.T & $r \ldots v$ & צ & إناث & \\
\hline
\end{tabular}




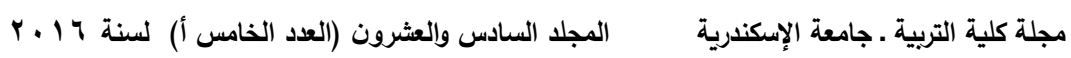

\begin{tabular}{|c|c|c|c|c|c|c|}
\hline \multirow{2}{*}{ غير دالة } & \multirow{2}{*}{$1 . \varepsilon \wedge$} & r.or & r..०ई & $|v|$ & ذكور & \multirow[t]{2}{*}{ الموجهات التربوية } \\
\hline & & צY.Y & rY..r & צזו & إناث & \\
\hline \multirow{2}{*}{ غير دالة } & \multirow{2}{*}{$.9 \varepsilon$} & אד.r & r...Y & $|v|$ & ذكور & \multirow[t]{2}{*}{ الموجهات السياسية } \\
\hline & & r.rA & r... & 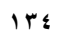 & إناث & \\
\hline \multirow{2}{*}{ غير دالة } & \multirow{2}{*}{$\ldots r$} & r.19 & YI.Y\& & ivi & ذكور & \multirow[t]{2}{*}{ الارجة الكلية } \\
\hline & & T.rq & r.ro & T & إناث & \\
\hline
\end{tabular}

يتضح من الجدول السابق عدم وجود فروق ذات دلالة إحصائية بين

الـكور والإنـاث في الموجهات الاجتماعيـة حيـث كانـت قيمـة "ت ץ ·. · وهـي غيـر دالـة إحصـائياً، كـذلك لا توجــ فـروق ذات دلالــة إحصائية بين الذكور والإناث في الموجهات الاقتصادية حيث كانت قيمة "ت" = وس. • ، وهى غير دالة إحصائياً، كما لا توجد فروق ذات دلالة إحصـائية بين الذكور والإنـاث في الموجهات التربويـة حيث كانت قيمـة "ت" = ^^ء. 1 ، وهي غير دالة إحصائياً، كما لا توجد فروق ذات دلالة إحصائية بين الذكور والإناث في الموجهات السياسية حيث كانت قيمة "ت" = ؟ 9 . ، ، وهى غير دالة إحصـائياً. و يظهر من الجدول السـابق أنه لا توجد فروق ذات دلالة إحصائية بين الذكور و الإناث في الدرجة الكلية، حيث كانت قيمة "ت" = 01. . ، وهى غير دالة إحصائياً. وذلك راجـع إلىى وعـي أفراد العينـة بأهميـة القضـية المطروحـة باعتبـارهم آبـاء وأمهات يدركون الطلب الاجتمـاعي على الجامعات العـابرة للحدود في ضـوء مجتمـع المعرفـة. وربمـا يكـون ذلـك راجع أيضـاً للـوعي المتــامي بأهمية التعليم عامة والتعليم المرتكز على أنماط دولية داخل المملكة في سد الفجوة بين المجتمع السعودي وبلدان المنشأ بالنسبة للجامعات العابرة للحدود. - متغير التخصص: 
تم حساب المتوسطات الحسابية والانحرافات المعيارية لكل مجال من المجالات الأربعة بالنسبة للتخصصات الأدبية و العلمية، وكذلك قيم "ت ودلالتها الإحصائية، ويمكن عرض ما توصل إليه الباحث من نتائج على الإلى

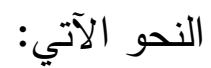
جدول (r I ) يوضح الأعاد والمتوسطات والانحرافات المعيارية وقيمة "ت" ودلاتها في

\begin{tabular}{|c|c|c|c|c|c|c|}
\hline مستوى الدلالة & ت & $\varepsilon$ & م & ن & التخصص & المجال \\
\hline \multirow{2}{*}{ غير دالة } & \multirow{2}{*}{.$\wedge \varepsilon$} & r.rs & ri.rv & 174 & أدبى & \multirow[t]{2}{*}{ لموجهات الاجتماعية } \\
\hline & & r.Ir & M.1. & $1 \leqslant r$ & علمى & \\
\hline \multirow{2}{*}{ غير دالة } & \multirow{2}{*}{$.0 \leqslant$} & $r .00$ & $r \ldots r$ & 174 & أدبى & \multirow[t]{2}{*}{ الموجهات الاقتصادية } \\
\hline & & r.74 & r..ro & $1 \leqslant r$ & علمى & \\
\hline \multirow{2}{*}{ غير دالة } & \multirow{2}{*}{$.7 V$} & $r . . v$ & 51.70 & 174 & أدبى & \multirow[t]{2}{*}{ الموجهات التربوية } \\
\hline & & Y.70 & rI.AV & $1 \leqslant r$ & علمى & \\
\hline \multirow{2}{*}{ غير دالة } & \multirow[t]{2}{*}{1.20} & $\varepsilon . .1$ & $r . .10$ & 174 & أدبى & \multirow[t]{2}{*}{ الموجهات السياسية } \\
\hline & & Y.Ar & $r \cdot . V \leq$ & $1 \leqslant r$ & علمى & \\
\hline \multirow{2}{*}{ غير دالة } & \multirow{2}{*}{. .09} & $1 \% .71$ & Ar.rr & 174 & أدبى & \multirow[t]{2}{*}{ الارجة الكلية } \\
\hline & & A.or & Ar.97 & $1 \leqslant r$ & علمى & \\
\hline
\end{tabular}

يتضح من الجدول السابق عدم وجود فروق ذات دلالة إحصائية بين التخصصات الأدبية والعلمية في الموجهات الاجتماعية حيث كانت

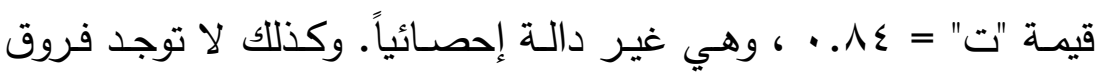

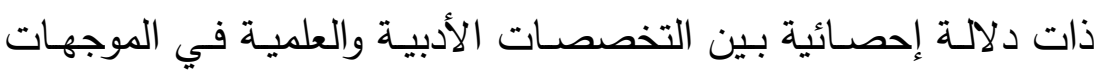

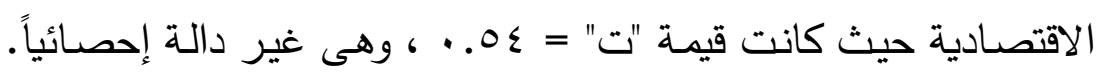

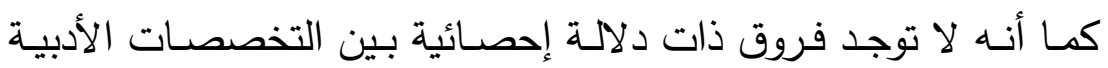

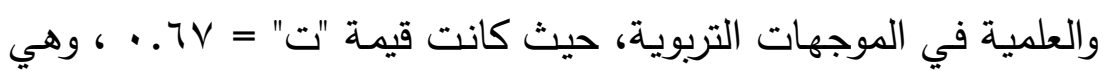

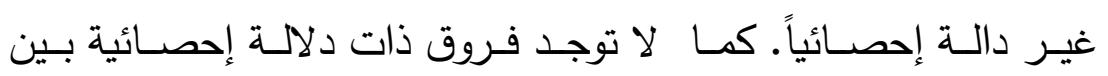
التخصصات الأدبية والعلمية في الموجهات السياسية، حيث كانت قيمة

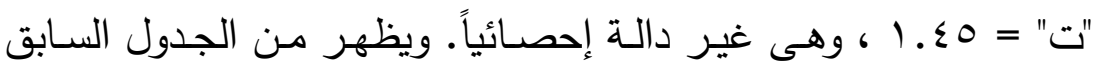
عدم وجود فروق ذات دلالة إحصائية بين التخصصات الأدبية والعلمية

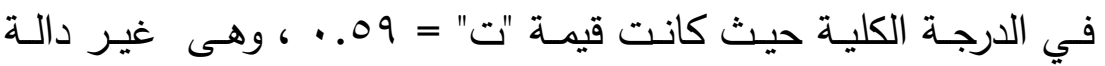

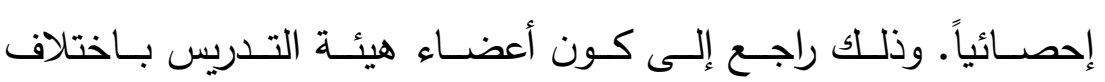


تخصصـاتهم يقدرون الـدور الفعلـي والحيـوي لفـروع الجامعـات العـابرة

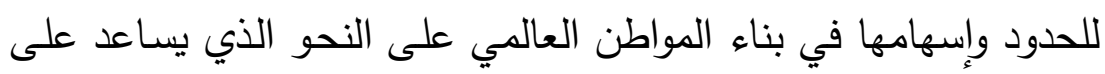
ربط خبرات الطالب بالعالم خارج أسوار المؤسسة التعليمية.

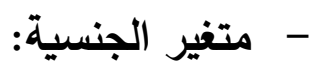
تم حساب المتوسطات الحسابية والانحرافات المعيارية لكل مجال

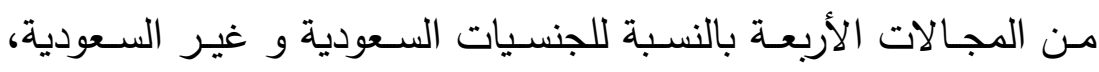
وكذلك قيم "ت" و دلالتها الإحصـائية، ويمكن عرض مـا توصل إليه الباحث من نتائج على النحو الآتي:

جدول (r ا ) يوضح الأعداد والمتوسطات والانحرافات المعيارية وقيمة "ت" ودلالتها في مجالات

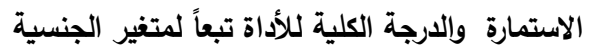

\begin{tabular}{|c|c|c|c|c|c|c|}
\hline مستوى الدلالة & $ت$ & $\varepsilon$ & s & ن & الجنسية & 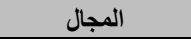 \\
\hline \multirow{2}{*}{ غير دالة } & \multirow{2}{*}{. .11} & r.09 & rI.ru & $11 r$ & سعودى & \multirow{2}{*}{ الاجتماعية } \\
\hline & & r.A9 & r.ru & 194 & غير سعودى & \\
\hline \multirow{2}{*}{ غير دالة } & \multirow{2}{*}{. .79} & r. $9 \mathrm{~V}$ & $r \cdot . r)$ & $11 \%$ & سعودى & \multirow{2}{*}{ الاقتصادية } \\
\hline & & T.rV & r...o & 194 & غير سعودى & \\
\hline \multirow{2}{*}{ غير دالة } & \multirow{2}{*}{$\ldots r$} & r.v. & ru.v & $11 r$ & سعودى & \multirow[t]{2}{*}{ الموجهات التربوية } \\
\hline & & r.91 & ru.vo & 194 & غير سعودى & \\
\hline \multirow{2}{*}{ غير دالة } & \multirow[t]{2}{*}{..\&1 } & r.ru & $r . .0 \varepsilon$ & $11 r$ & سعودى & \multirow[t]{2}{*}{ الموجهات السياسية } \\
\hline & & r.71 & r..ru & 194 & غير سعودى & \\
\hline \multirow{2}{*}{ غير دالة } & \multirow{2}{*}{$\because+9$} & $1 \ldots r$ & $\Lambda T . \wedge 1$ & $11 \%$ & سعودى & \multirow[t]{2}{*}{ الارجة الكلية } \\
\hline & & $11 . \leqslant 0$ & Ar.s\% & $19 \%$ & غير سعودى & \\
\hline
\end{tabular}

يتضح من الجدول السابق عدم وجود فروق ذات دلالة إحصائية بين الجنسيات السعودية وغير السعودية في الموجهات الاجتماعية حيث كانت

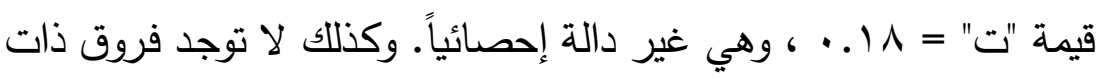


دلالة إحصـائية بين الجنسيات السعودية وغير السـودية في الموجهات الاقتصادية حيث كانت قيمة "ت" = 79 . . ، وهى غير دالة إحصائياً. كما

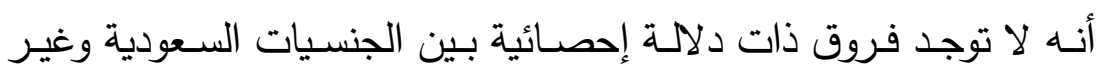

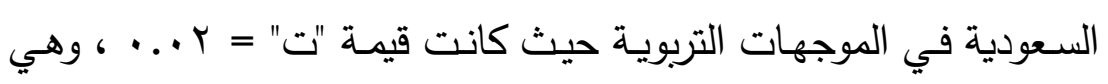
غير دالة إحصائياً. كما لا توجد فروق ذات دلالة إحصائية بين الجنسيات السعودية و غير السعودية في الموجهات السياسية حيث كانت قيمة "ت اتل

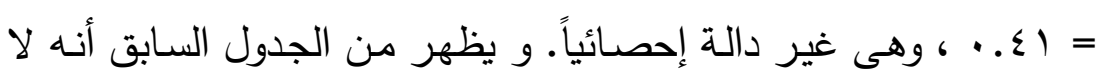
توجد فروق ذات دلالة إحصائية بين الجنسيات السعودية و غير السعودية

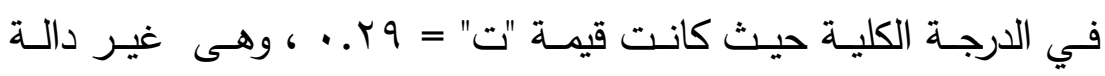
إحصائياً. وقد يرجع ذلك إلى أن هناك ثقافة مشتركة بين أعضـاء هيئة التدريس - السعوديين والمتعاقدين - على اعتبار أن ثقافة عربية واحدة

تجمعهم.

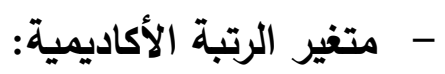

تم حسـاب المتوسطات الحسابية والانحرافات المعياريـة لكل مجال من

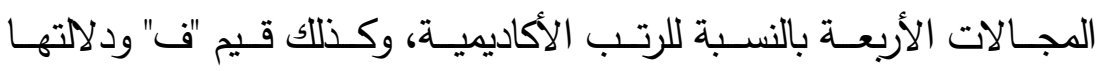

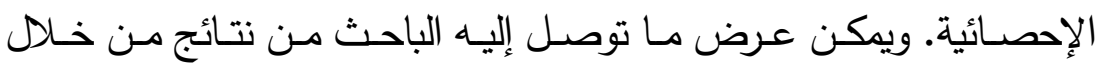
الجدولين التاليين: - الإنه جدول (\& ) الأعداد والمتوسطات والانحرافات المعيارية فى جميع مجالات الاستبانة

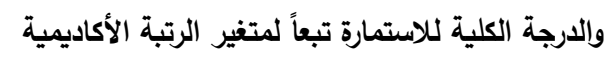

\begin{tabular}{|c|c|c|c|c|}
\hline$\varepsilon$ & 5 & ن & الرتبة الأكاديمية & المجال \\
\hline Y.A4 & 1.17 & 197 & أستاذ مساعد & \multirow{3}{*}{ الموجهات الاجتماعية } \\
\hline r.90 & ri.ra & Vr & أستاذ مشارك & \\
\hline $1.9 \leq$ & r.. $\leqslant 1$ & rv & أستاذ دكتور & \\
\hline r... & $19.9 \mathrm{~V}$ & 197 & أستاذ مساعد & \multirow{3}{*}{ الموجهات الاقتصادية } \\
\hline r.ro & $r . .0 \leqslant$ & vr & أستاذ مشارك & \\
\hline r.rY & $r . . r r$ & rv & أستاذ دكتور & \\
\hline
\end{tabular}




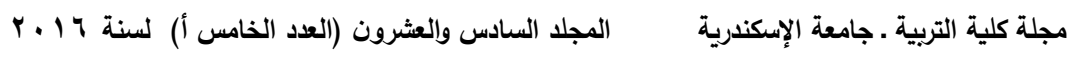

\begin{tabular}{|c|c|c|c|c|}
\hline r.AA & ru.v. & 197 & أستاذ مساعد & \multirow{3}{*}{ الموجهات التربوية } \\
\hline$r .1 \%$ & $r 1.9 \mathrm{~V}$ & Vr & أستاذ مشارك & \\
\hline r.ru & $r 1.09$ & $r v$ & أستاذ دكتور & \\
\hline$r .04$ & $r . . \leqslant 0$ & 194 & أستاذ مساعد & \multirow{3}{*}{ الموجهات السياسية } \\
\hline$r .71$ & r.... & VY & أستاذ مشارك & \\
\hline r... & $r . .14$ & rv & أستاذ دكتور & \\
\hline $1 . .19$ & AT.rA & 194 & أستاذ مساعد & \multirow{3}{*}{ الدرجة الكلية } \\
\hline 14.11 & $\wedge \leqslant . \leqslant$. & VY & أستاذ مشارك & \\
\hline $9 . \leqslant Y$ & $\Delta r . \leqslant 9$ & $r v$ & أستاذ دكتور & \\
\hline
\end{tabular}

يبين الجدول السـابق المتوسـات الحسـابية والانحرافات المعياريـة

لاستجابات أعضـاء هيئة التدريس في كل مجال من مجالات الاستمارة والاستمارة ككل. وبالنظر في قيم المتوسطات الحسابية الواردة في الجدول السابق يتبين عدم وجود فروق ظاهرية بين متوسطات استجابات أعضاء هيئة التدريس في كل مجال مـن مجالات الاستمارة تعزى إلى متغيـر الرتبـة الأكاديميـة. ولمعرفـة دلالـة هـذه الفـروق تـم إجـراء تحليـل التبـاين

الأحادي. وجاءت النتائج على النحو الآتي:

جدول (0 1 ) تحليل التباين الأحادي للمقارنة بين متوسطات

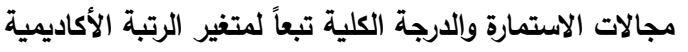

\begin{tabular}{|c|c|c|c|c|c|c|}
\hline مستوى الدلالة & قيمة ف & متوسط & الحرية & المربعات & مصدر التباين & المجال \\
\hline \multirow{3}{*}{ غير } & \multirow{3}{*}{ r.ro } & 1.97 & $r$ & r.qr & بين المجموعات & \multirow{3}{*}{ الاجتماعية } \\
\hline & & V.V & $r \cdot r$ & $r r \leq r . I r$ & داخل المجموعات & \\
\hline & & & $r \cdot \varepsilon$ & $r r \leq 4 . .0$ & الكلى & \\
\hline \multirow{3}{*}{ غير } & \multirow{3}{*}{$.9 r$} & $9 . Y \wedge$ & $r$ & 11.04 & بين المجموعات & \multirow{3}{*}{ الاقتصادية } \\
\hline & & $1 \ldots$ & $r \cdot r$ & $r .19 . \Lambda$. & داخل المجموعات & \\
\hline & & & $r \cdot \varepsilon$ & r.rA.ru & الكلى & \\
\hline \multirow{3}{*}{ غير دالة } & \multirow{3}{*}{$\because$ rq } & $r . \varepsilon T$ & r & ؛.Aт & بين المجموعات & \multirow{3}{*}{ الموجهات التربوية } \\
\hline & & A.rr & $r \cdot r$ & roll.v. & داخل المجموعات & \\
\hline & & & $r \cdot \varepsilon$ & r017.07 & الكلى & \\
\hline \multirow{3}{*}{ غير دالة } & \multirow{3}{*}{. $.1 r$} & $1.0 \leqslant$ & $r$ & $r . . v$ & بين المجموعات & \multirow{3}{*}{ الموجهات } \\
\hline & & $1 Y . \leq 4$ & $r \cdot r$ & rVTl.or & داخل المجموعات & \\
\hline & & & $r \cdot \varepsilon$ & PVqะ.०q & الكلى & \\
\hline
\end{tabular}




\begin{tabular}{|c|c|c|c|c|c|c|}
\hline الدلالة & قيمة ف & مجموسط & درجات & المربعات & مصدر التباين & 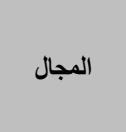 \\
\hline \multirow{3}{*}{ غير دالة } & \multirow{3}{*}{.$r V$} & rr.r. & $r$ & 74.71 & بين المجموعات & \multirow{3}{*}{ الدرجة الكلية } \\
\hline & & $14 . .17$ & $r \cdot r$ & rצYA1.IT & داخل المجموعات & \\
\hline & & & $r \cdot \varepsilon$ & r.VE. & الكلى & \\
\hline
\end{tabular}

يتضـح من الجدول السـابق عدم وجود فروق ذات دلالـة إحصـائية

بين الرتب الأكاديميـة المختلفـة في الموجهات الاجتماعية حيث كانـ

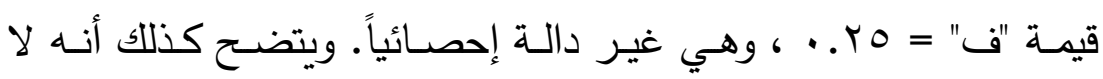
توجـد فـروق ذات دلالــة إحصـائية بـين الرتـب الأكاديميـة المختلفـة في الموجهات الاقتصـادية حيث كانت قيمـة "ف" = سو9. • ، وهي غير دالة

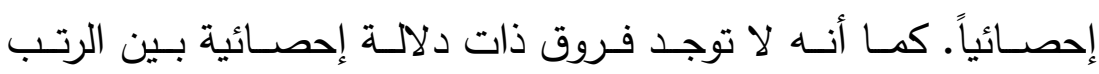
الأكاديميـة المختلفــة في الموجهـات التربويـة، حيــث كانــ قيمـة "فـ 9 = . . ، وهي غير دالة إحصـائياً. كما يتضـح عدم وجود فروق ذات دلالة إحصائية بين الرتب الأكاديمية المختلفة في الموجهات السياسية،

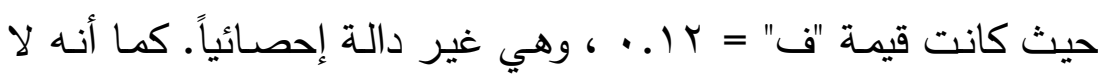
توجـد فروق ذات دلالـة إحصـائية بـين الرتـب الأكاديميـة المختلفـة في

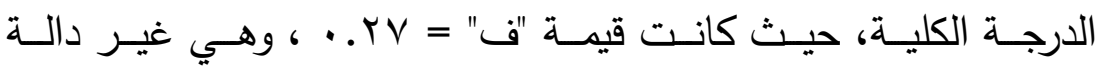
إحصـائياً. وقد يرجـ ذلك إلى تشـابه الظروف الوظيفيـة لأعضـاء هيئة التدريس مـ حرصهم على التصدي للتحديات التي تواجه التعليم العالي السعودي، وكذلك من منطلق الحاجة لتعزيز جودة التعليم العـالي التي أصبحت تشكل هاجساً للكثيرين منهم. إيجابيات وسلبيات الترخيص لفروع جامعات عابرة للحدود بالمملكة العربية السعودية على ضوء رؤى التغيير المستقبلية عالمياً ومحلياً أدت الجامعــات السـعودية دوراً مههــاً فـي التحـولات التـي شـــهـا المجتمع، ومع ذلك ما زالت تحتاج إلى تطوير وتجديد لتواكب ما يجري في المجتمعات الحديثة. ومهما يكن من أمر فإن واقع التعليم العالي في المملكة 
العربية السعودية يعد المحرك الأساسي للنهوض بالأمة، كما يشكل المدخل

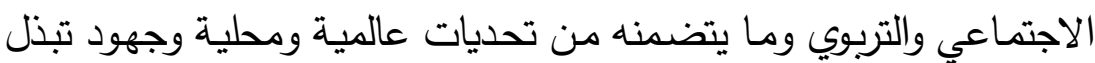
لمواجهتهـا بدايـة رئيسـة تعبـر مـن خلالهـا الدراســة إلـى فهم وطـرح فكرة الترخيص لفروع جامعات عابرة للحدود كأحد مسارات التطوير في منظومة التعليم العـالي السعودي ويتلمس ضـرورات التجديد التربوي لهذا النوع مـن التعليم. ومـع تصـاعد الحوار والجدل على المستوى الفكري وآفاق المستقبل تبقى الأطـر السـابقة أداة ضـاغطة باتجـاه تبنـي مطلب التطـوير والتجديــا باعتبارة من الأولويات السياسية والاجتماعية والاقتصادية والثقافية للمملكة العربية السعودية. هذا بالاضافة إلى ما طرحته الدراسة من نتائج سواء على لـى المستوى النظري أو الميداني والذي يؤكد على عدة نقاط على درجة عالية الئل

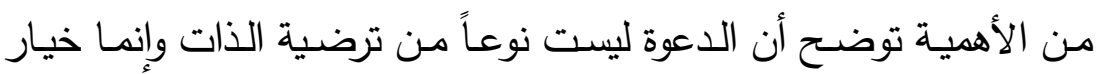

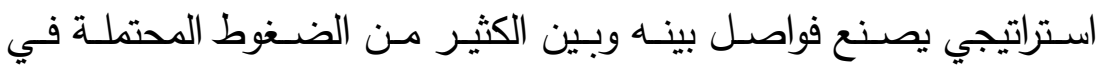
المستقبل ويمكن إجمالها فيما يلي:

1- يرى أعضـاء هيئة التدريس الموجهات الدافعـة نحو الترخيص لفروع

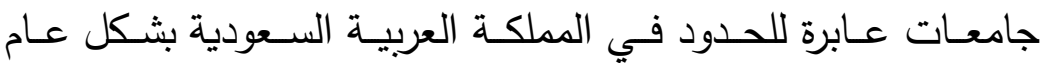

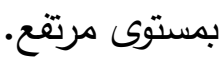

r- جـاءت الموجهـات التربويـة في المرتبــة الأولـى في الترتيـب يليهـا

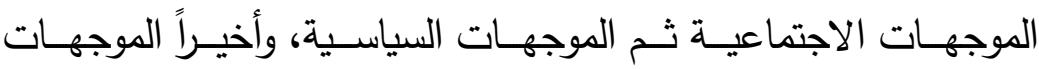

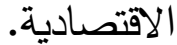

r- عـدم وجـود فـروق ذات دلالـــة إحصـائية بـين متوسـطات تقـدير

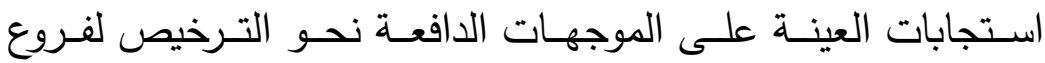
جامعات عابرة للحدود في المملكة العربية السعودية تعزى لمتغيرات: النوع، التخصص، الجنسية، الرتبة الأكاديمية. 
؟- أن المجتمع السعودي - مثله مثل العديد من المجتمعات التي تسعى إلى التتميـة المستدامة وفق متطلبات العصر - في حاجـة إلى تدعيم تعليمه العالي والجامعي بفروع لجامعات دولية وفق صيغ التعليم العالي

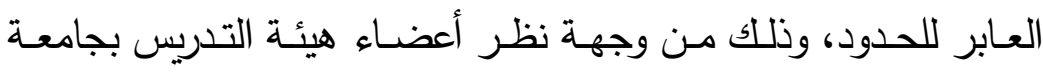
الأمام.

0- أن هناك العديد من الموجهات التربوية ذات العلاقة المباشرة بالارتقاء

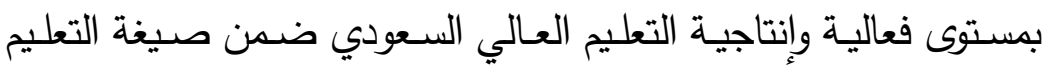
العابر للحدود المتكامل مع التعليم العالي بالمملكة العربية السعودية.

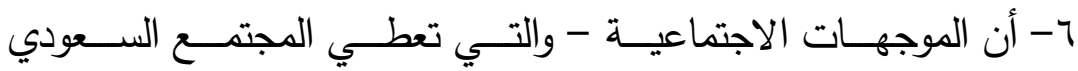
خصوصيته وتميزه - تجعل قرار غرس فروع جامعات عابرة للحدود في

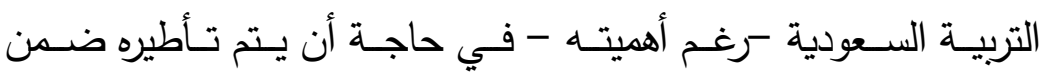
المنظومة الاجتماعية والبنية الثقافية السعودية. V - أن الجوانب والأبعاد السياسية داعمة ومشجعة وليه على الاستعانة بالتعليم

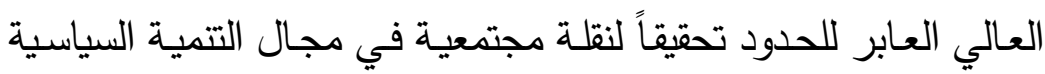
وبما يتوافق وطبيعة المجتمع السعودي.

1- أن البعد الاقتصادي - رغت وطم أهميته - أتى في المرتبة الأخيرة. وذلك

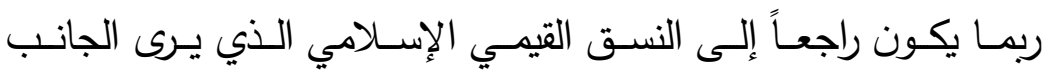
الاقتصادي وسيلة وليس غاية.

9- أن هناك العديد من التجارب العربية والإسـلامية والعالمية التي سبقت ولته في مجال التوظيف المجتمعي للتعليم العالي العابر للحدود وثبت جدوى وفعالية هذه التجارب، الأمر الذي يثجع على خوض التجربـة بالمملكة العربية السعودية. • 1- وعلى الرغم ممـا قدمته الدراسـة من وجهات نظر وقناعات تؤكد على أهمية الترخيص لفروع جامعات عابرة للحدود في المملكة العربية 
السـودية إلا أنـه يمكن تسـجيل بعض الإيجابيـات وسـبل تـدعيمها،

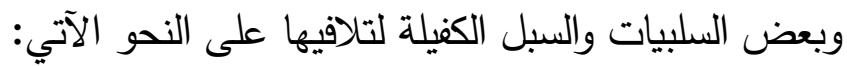
أولاً: الإيجابيات:

هنالك بعض الإيجابيات نتيجة التزام هذا التوجه يمكن عرضها كما

- سيزيد من قدرة الطلاب بالمملكة على الاختيار المهني والأكاديمي بما يتوافق وقدراتهم.

- سـيزيد مـن المنافسـة المنتجـة بين قطـاعي التعليم المحلـي والعـابر للحدود لصالح الممارسة التربوية المتميزة.

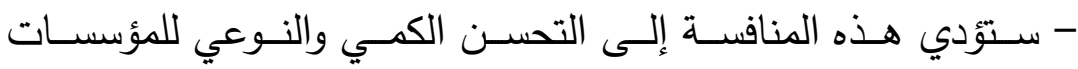
التعليمية العالية.

- سوف يؤدي إلى الارتقاء بمستوى المخرجات التعليمية. - توفير المهارات التقنية المطلوبة لسوق العمل محلياً واقليمياً وعالمياً. - الارتقاء بالبنية العقلية والنفسية لأبناء المجتمع من خلال الاحتكاك بخبرات تعليمية تثقيفية عالمية.

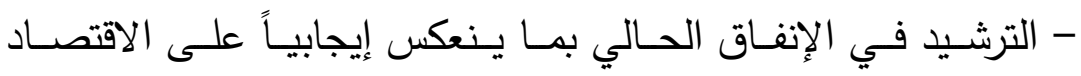
بالمملكة.

ومن أجل تدعيم الإيجابيات ينبغي: العمله - أن توفر الحكومة الحوافز للجامعات العابرة للحدود. - العمل على توفير المناخ المجتمعي اللازم لنجاحها. ثانياً: السلبيات هناك بعض السلبيات نتيجة التزام هذا التوجه يمكن عرضها كما يلي: - التجارة بالتعليم واستخدامه وسيلة لاختراق العقل العربي. - إضعاف التماسك الاجتماعي الذي يتميز به المجتمع السعودي. - وسيله لزيادة حدة التفاوت الطبقي. 
- تثكيك مقومات الهوية الثقافية للمجتمع السعودي.

\section{ومن أجل تلافي السلبيات ينبغي:}

- تنظيم دخول وتشغيل المؤسسات التعليمية العابرة للحدود التي تسعى إلى توفير التعليم العالي بحيث يجب أن لا تهدف للربح.

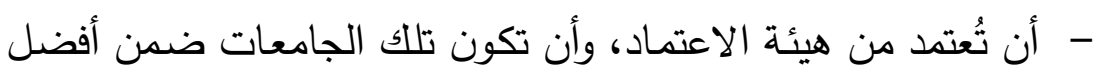

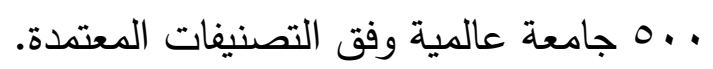

- أن يخضع أعضاء هيئة التدريس فيها لمعايير التوظيف والتدريس في

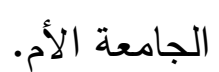

- تدريس مناهج الجامعة الأم مع إضافة بعض مواد الثقافة الإسلامية.

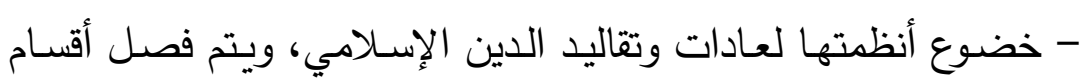

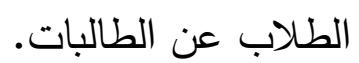

- تقديم الدورات التأهيلية قبل قبول أولئك الذين لا يستوفون المعايير المطلوبة في البداية للدخول.

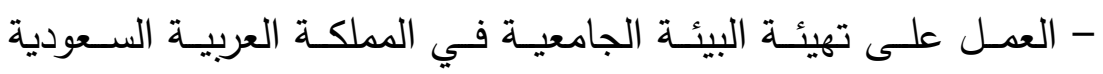

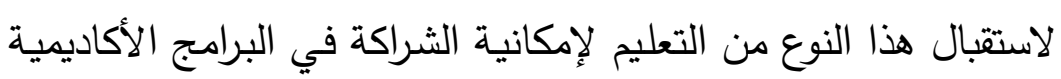

$$
\text { والبحثية. }
$$

- وضـع التشريعات اللازمة لتنظيم عمل فروع الجامعات العابرة للحدود بالمملكة العربية السعودية حتى لا تتحول إلى تجارة عابرة للحدود.

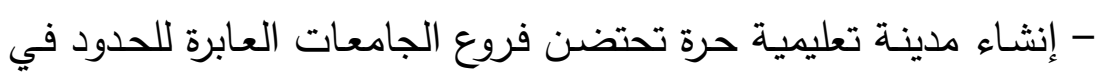
المملكة العربية السعودية.

- التركيز على الجامعـات الدولية المعتمدة بالفعل في بلدانها الأصلية ذات السمعة العلمية المرموقة في التصنيفات الدولية.

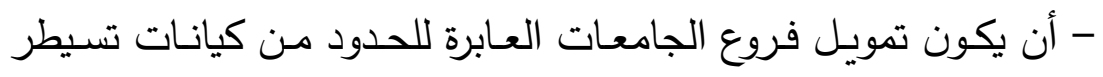
عليها الحكومة لتصبح جزءا من النظام التعليمي في المملكة العربية السعودية. 


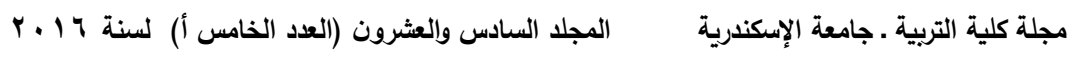

- أن تلتزم فروع الجامعات العابرة للحدود بمتطلبات الاعتماد والتقاليد الأكاديمية المعروفة في دولها.

- تشكيل لجنـة دوليـة لضـمان جـودة فـروع الجامعـات العـابرة للحدود

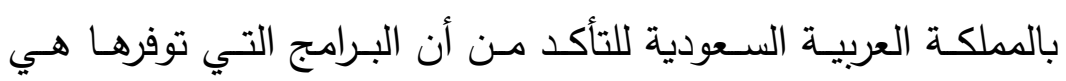
بالجودة نفسها التي تقدمها جامعاتها الأم.

لقد تعرضت هذه الدراسة لموضوع يتسم بالحساسية الثديدة، نتيجة

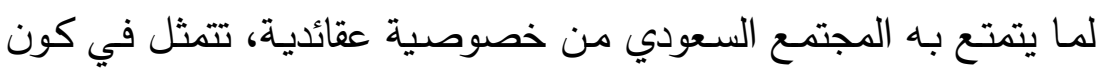
المملكة قبلة لكل مسلمي العالم، نتيجة لما متعها الله به من وجود الحرمين الثريفين (المسجد الحرام بمكة المكرمة- المسجد النبوي بالمدينة المنورة)

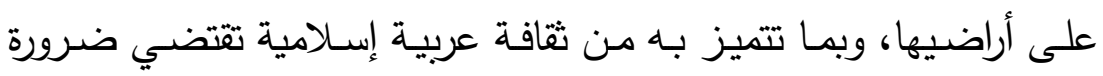

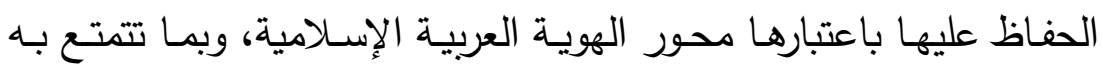

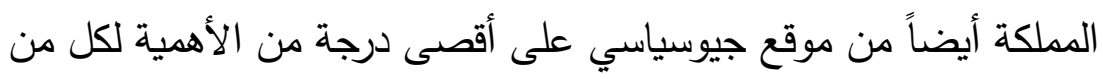

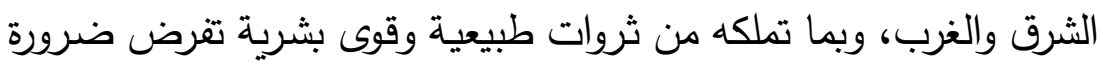

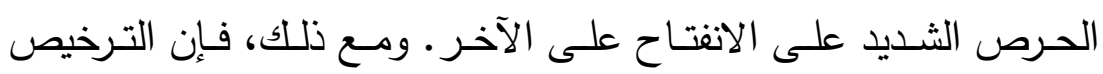

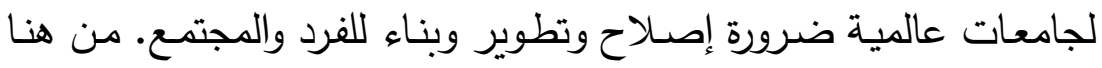
كانت المعالجة قائمة على حساسية الوعي بالواقع وعظم الأمل في مستقبل أفضل. 


\section{المصادر والمراجـع}

1. أبو عمة، عبدالرحمن (Tr () )، واقع الجامعات الاجنبية وفروعها في تتظيمات التعليم العالي، الرياض: مركز البحوث والإراسـات في في الدي التعليم العالي.

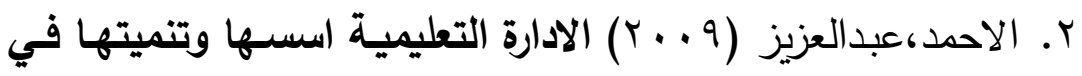

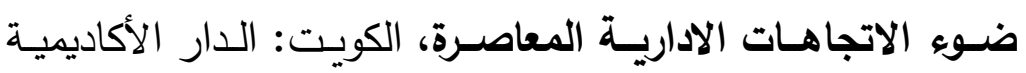
للنشر والتوزيع.

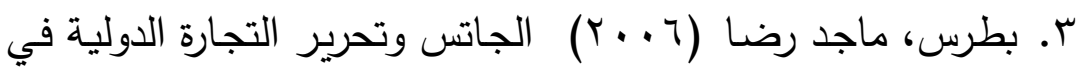
قطاع التعليم العالي في مصر، مجلد مجلة البحوث الاداريـة، أكاديمية

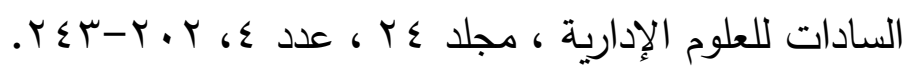

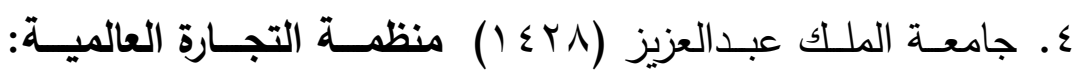

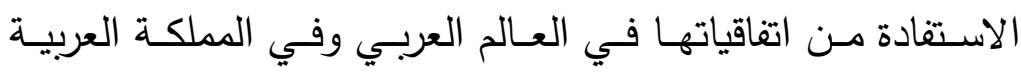

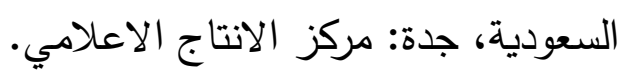

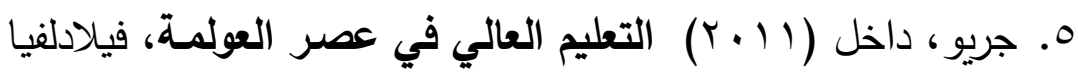

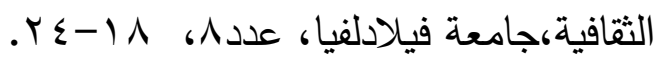

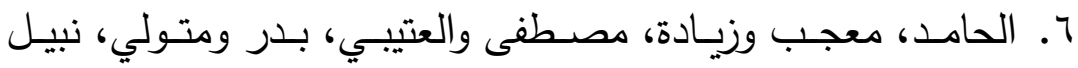

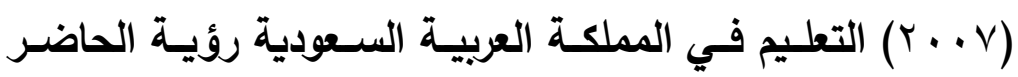
واستشراف المستقبل،طء، الرياض: مكتبة الرشد.

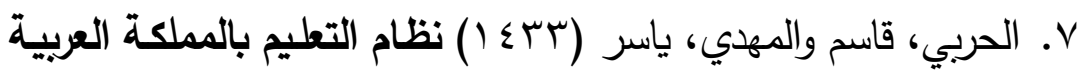

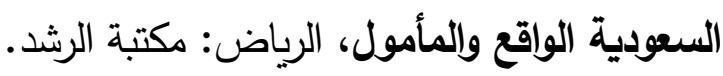

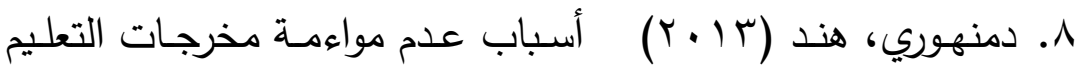

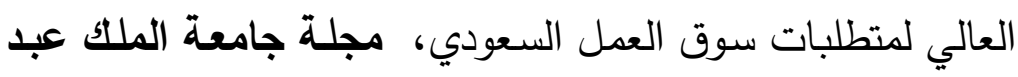

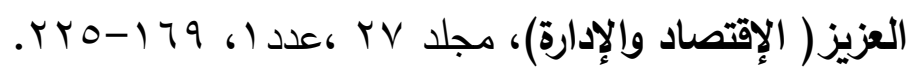


9. الذبياني، حمح (1) (1) دور الجامعـات السـودية في بنـاء مجتمع

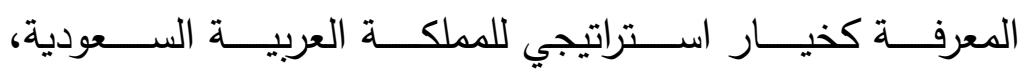

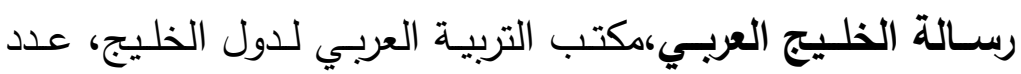

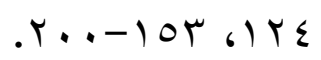

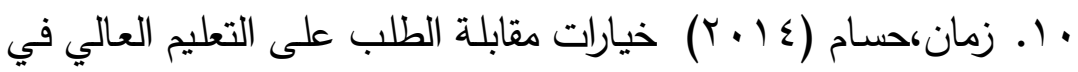

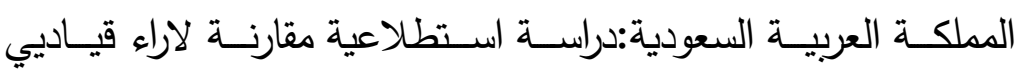

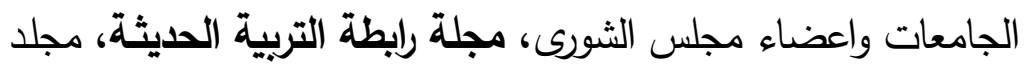

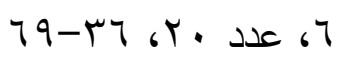

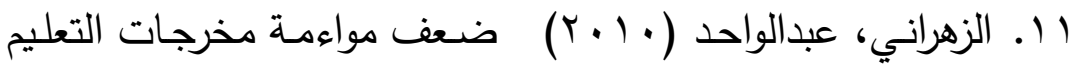
العالي السعودي من القوى البشرية المؤهلة لاحتياجات سوق العمل

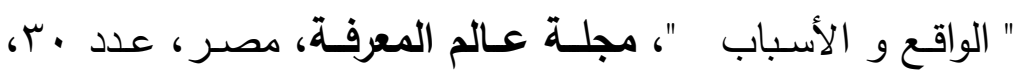

$$
\text { .rtr-tos }
$$

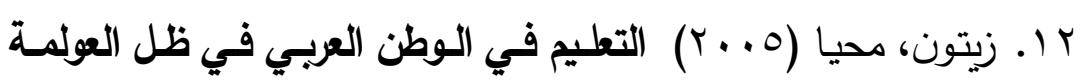
وثقافة السوق، بيروت: مركز دراسات الوحدة العربية.

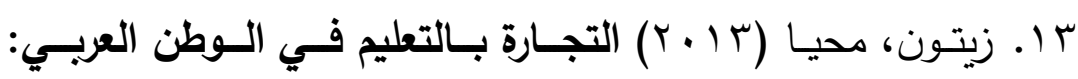

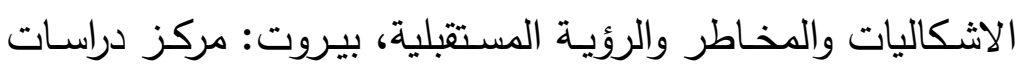

$$
\text { الوحدة العربية. }
$$

ـ ا. السروري، علي (9 . . r) محفزات الامتثال والانكفاف في ايات

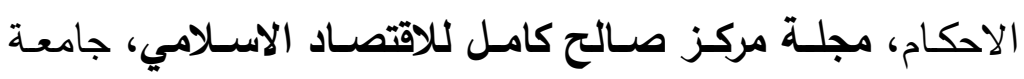

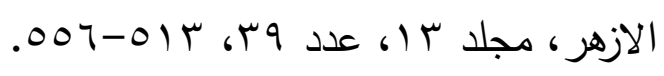

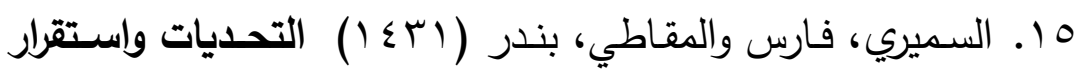

الامن الوطني السعودي، الرياض: دار المفردات للنشر والتوزيع.

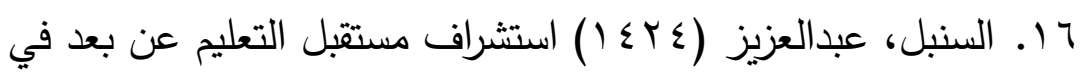

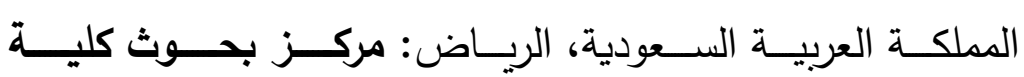
التربية/جامعة الملك سعود. 


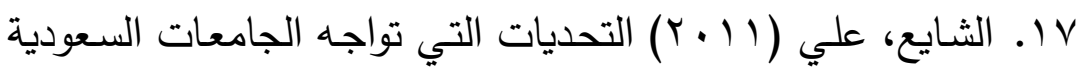

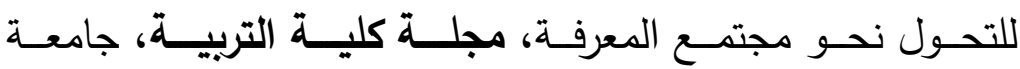

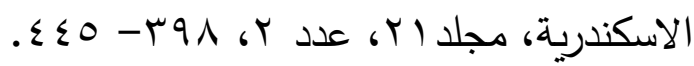

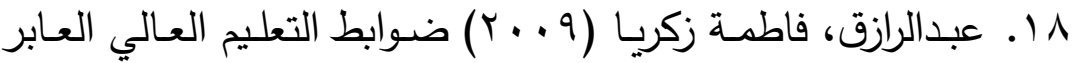
للحدود القومية بدصر في ضوء خبرات بعض الدول، المؤتمر

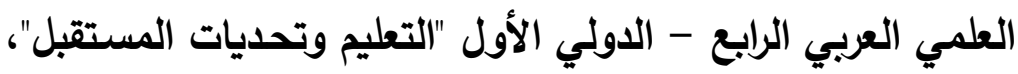

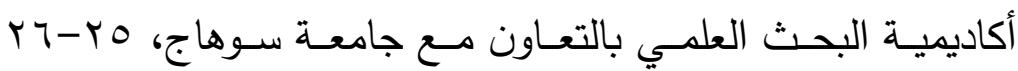
أبريل، سوهاج.

9 19. العتيبي، بدرية (ع ( • ب) المجتمع السعودي بين التغير والتغيير: دراسة سوسيولوجية، الرياض: مكتبة الرشد.

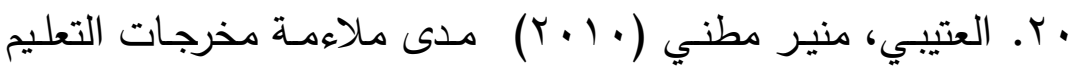
العالي لاحتياجات سوق العمل السعودي: دراسات تحليلية، المجلة ملئة

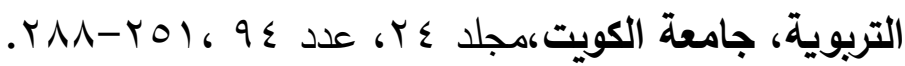

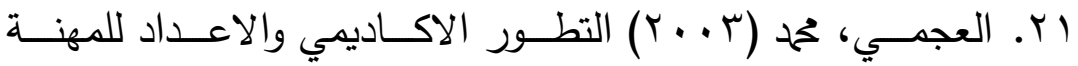
الأكاديميـة بالجامعـات المصـرية بـين تحديات العولمـة ومتطلبـات

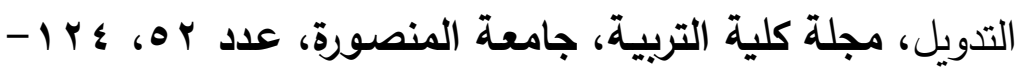
.191

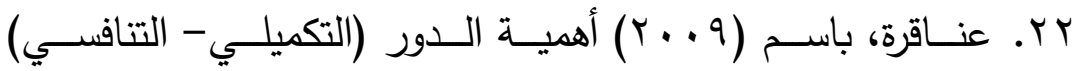

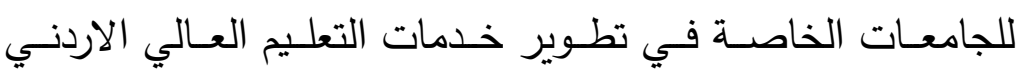

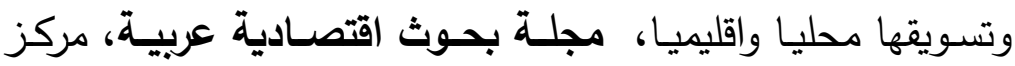

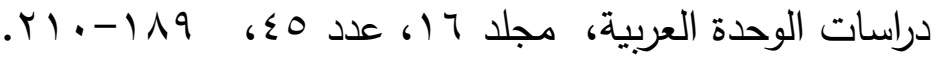


rr. العوهلي، حمد و العقيلي، عبدالمحسن (9 . . r) التعليم العالي في

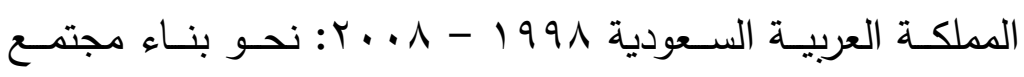
المعرفة، المؤتمر الاقليمي العربي "تحو فضاء عربي للتعليم العالي التحديات العالمية والمسؤوليات المجتمعية" مكتب اليونسكو الإقليمي للتربية في الدول العربية، اسمايو ب يونيو، القاهرة.

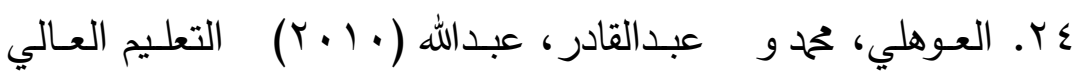
والجامعات السعودية: التحديات وبرامج التطوير ، المؤتمر العربي الثالث "الجامعات العربية: التحديات والآفاق"، 9 - 1 يناير، شرم • الشيخ

ه . الفـارس، فـارس (1991) مشــروع استثـراف مسـتقبل العمـل التربوي في دول الخليج العربية، الربـاض: مكتب التربية العربي لدول الخليج العربي.

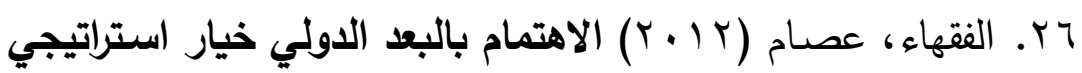
لتطوير الجامعات العربية: دراسة حالة جامعة فيلادلفيا في الاردن،

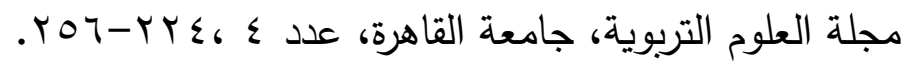
YV الخارجيـة للتعليم العـالي للفتاة ومتطلبات سوق العمل في المملكة العربية السعودية، المؤتمر العلمي الثامن للتربية "جودة واعتمـاد مؤسسـات التعليم العـام في الـوطن العربـي"، بr - ع ع مـايو،

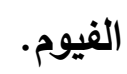

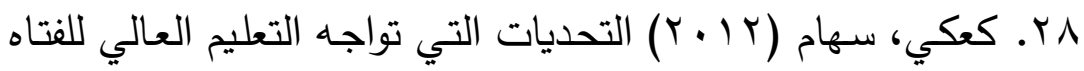
في المملكـة العربيـة السـودية، مجلــة العلـوم التربويـة، ، جامعـة

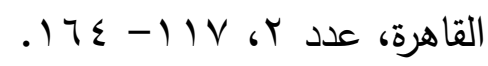

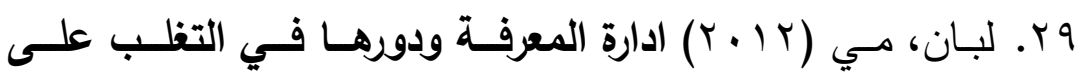
التحديات التي تواجه التعليم العالي بالمملكة، دراسات عربية في 


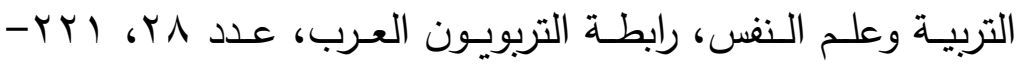
$. r \leq 7$

• r. مجلس الغـرف التجاريـة الصـناعية السـودية (ابـ؛ () الاتفــاق العـام للتجـارة فـي الخــمات، الريـاض: ادارة البحوث والدراسـات الاقتصادية.

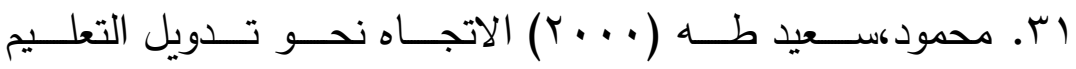
العالي:العوامل والملامح والمتطلبات، مجلة كلية التربية بالزقازيق،

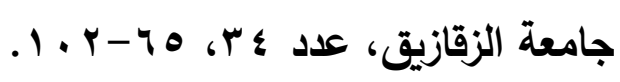

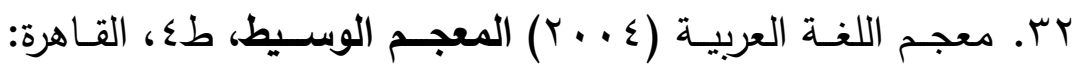
مكتبة الشروق.

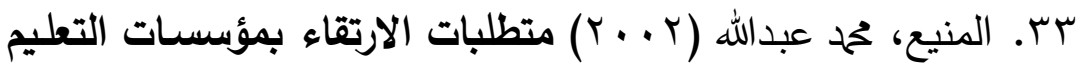
العـالي لتنميـة المـوارد البثـرية في المملكـة العربيـة السـعودية:

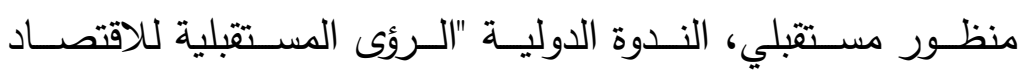

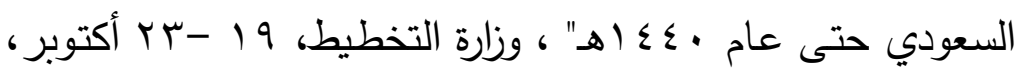

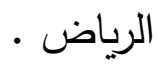

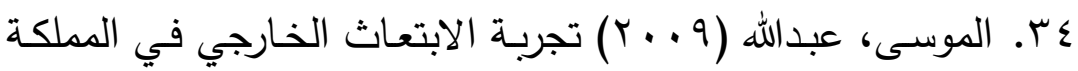
العربية السعودية: نموذج للاستثمار في الكفاءات البشرية وإسهامها في التتمية، المؤتمر الإقليمسي العربي "تحو فضساء عربي للتعليم العالي والتحديات العالمية والمسؤولية المجتمعية"، مكتب اليونسكو الإئهي الإقليمي للتربية في الدول العربية، اب مايو - ب يونيو، القاهرة.

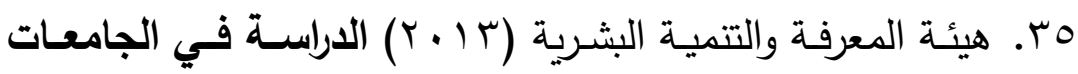
الدولية في دبي، دبي: حكومة دبي.

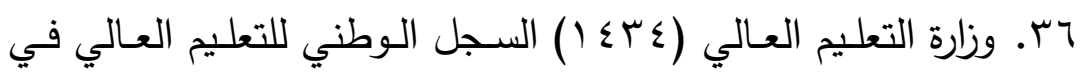

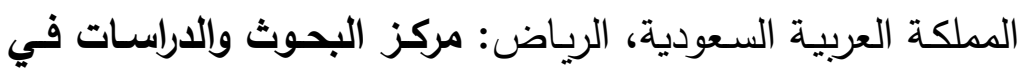
التعليم العالي. 


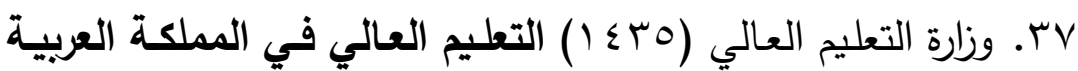

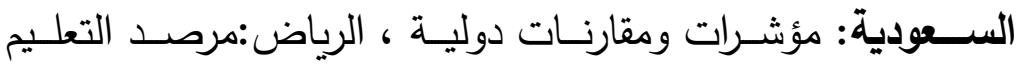

العالي.

مب. وطفـة ، على ( ب99 1) ـ " التحـديات الإعلاميـة فـى الـوطن

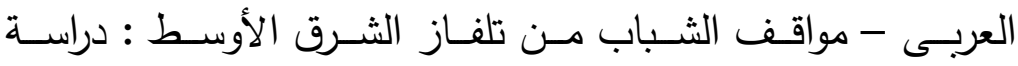

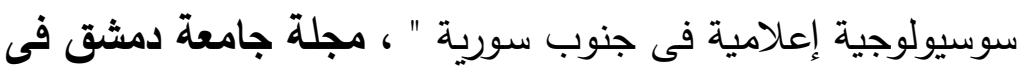

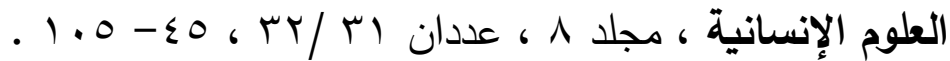

39. Altbach, P. \& Knight، J. (2007) the Internationalization of Higher Education: Motivations and Realities, Journal of Studies in International Education, 11(3), Pp. 290-305.

40. Anderson, G. \& Arsenault, N. (2000) Fundamentals of Educational Research, 2nd Edition, New York: Routledge Taylor \& Francis Group.

41. Aqeel, M. (2014) Foreign Universities Could Be Good For the Gulf, Yemen Times News Papers, Feb 20.

42. Mahani, S. \& Molki,A. (2011) Internationalization of Higher Education: A Reflection on Success and Failures Among Foreign Universities in The United Arab Emirates, Journal of International Education Research,7(3), Pp. 1-8.

43. Bagaresh, A. (2013) Accession of Kingdom of Saudi Arabia's to World Trade Organization and Its Benefits, Proceedings of 23rd International Business Research Conference, 18 20 Novembe, Melbourne, Australia.

44. Clark,N.(2015 A) Established and Emerging Hubs for International Education in Africa and 
The Middle East, World Education News \& Reviews, Published: June 2 .

45. Clark, N. (2015 B) Developing International Education Hubs in Asia, World Education News \& Reviews, Published: July 8.

46. David, S. \& Danny, W. (2006) Dealing With Cross-Border Higher Education: Comparing the Chinese and the Indian Ways, Tertium Comparationis, 12(2), Pp.145-163.

47. Egle, G. \& Asta, R. (2014) International Branch Campus: Framework and Strategy, Procedia Social and Behavioral Sciences (110), Pp. 301 308.

48. Ennew, C. \&Fujia, Y. (2009). Foreign Universities in China: A Case Study, European Journal of Education, 44 (1), Pp. 21 - 34.

49. Fielden, J. (2012) Sri Lanka As An Education Hub For International Students: The Road Ahead, South Asia Human Development Sector, Report (50), January.

50. Garwe, E. (2015) Managing the Quality of CrossBorder Higher Education in Zimbabwe, Journal of Education and Training Studies, 3(2), Pp.44-50.

51. Khodr,H. (2011) The Dynamics of International Education in Qatar: Exploring The Policy Drivers Behind The Development of Education City, Journal of Emerging Trends In Educational Research and Policy Studies, 2 (6), Pp. 514-525.

52. Knight, J. (2003) Gats, Trade and Higher Education-Perspective 2003: Where Are We?', 
London: The Observatory on Borderless Higher Educatio.

53. Knight, J. (2002) Trade in Higher Education Services: The Implications of Gats, London: The Observatory on Borderless Higher Education.

54. Lane, J. \&Kinser, K. (2011) Reconsidering Privatization in Cross-Border Engagements: The Sometimes Public Nature of Private Activity, Higher Education Policy, (24), Pp. 255-273.

55. Merey,G. \& Alkan,R. (2015) An Overview of Nternational Education in Higher Education From A Macro Perspective, The Online Journal of New Horizons in Education, 5(2), Pp.1-5.

56. Ministry of Higher Education (2010) Foreign University Branch Campus Programmes, Putrajaya /Malaysia: Department of Higher Education.

57. Mitra, S. (2010) Internationalization of Education in India: Emerging Trends and Strategies, Asian Social Science, 6(6), Pp. 105110.

58. Mok, M. (2007) Questing For Internationalization of Universities in Asia: Critical Reflections, Journal of Studies in International Education, 11(3-4), PP. 433454.

59. Njuguna, F. \& Itegi, F. (2013) Cross-Border Higher Education In Frica: The Kenyan Experience, Journal of Emerging TreNds in Educational Research and Policy Studies, 4 (5), PP. 752-759. 
60. Nyahoho, E. (2011)International Trade in Education Services: Its Scope and Challenges Associated With Liberalisation, Journal of Economic \& Social Policy, 14(1), PP. 179- 209.

61. Olds, K. (2007) Global Assemblage: Singapore, Foreign Universities, and the Construction of A “Global Education Hub”, World Development, 35(6), Pp. 959-975.

62. Qiang, Z. (2003) Internationalization of Higher Education: Towards A Conceptual Framework, Policy Futures in Education, 1(2), Pp. 248-270.

63. Sardana, J. \& Hoth, B. (2011) Entry of Foreign Universities and Their Impact on the Indian Education System, International Journal of Multidisciplinary Research, 1(4), PP. 163-174.

64. Sife, A., Lwoga, E. \& Sanga, C. (2007) New technologies for teaching and learning: Challenges for higher learning institutions in developing countries, International Journal of Education and Development using Information and Communication Technology, 3(2), pp. 57-67.

65. Tilak, J. (2011) Trade in Higher Education: The Role of The General Agreement on Trade in Services (Gats), Paris: International Institute For Educational Planning.

66. UNESCO (2005) Quality Provision In CrossBorder Higher Education, Drafting Meeting 3 "Capacity Building Activities In Qualifications Recognition Quality Assurance and Accreditation: 
Towards A Coherent Framework ", 17-18 January, Paris.

67. Varghese, N. (2011) Globalization and Cross Border Education: Challenges for the Development of Higher Education in Commonwealth Countries, Paris: UNESCO / International Institute for Educational Planning.

68. Verger, A. (2010) Wto/Gats and the Global Politics of Higher Education. London-New York: Routledge.

69. Wilkins, S. (2010). Higher Education in the United Arab Emirates: An Analysis of the Outcomes of Significant Increases in Supply and Competition. Journal of Higher Education Policy and Management, 32 (4), PP. 389-400.

70. Wilkins, S. (2011). Who Benefits From Foreign Universities In The Arab Gulf States? Australian Universities' Review, 53 (1), Pp. 73-83.

71. Wilkins, S., \& Huisman, J. (2012) the International Branch Campus as Transnational Strategy in Higher Education. Higher Education, 64(5), PP.627- 645.

72. Witte, Spencer (2010) Gulf State Branch Campuses, International Higher Education, (58), Pp. 5-6.

73. Zeeshan, M., Sabbar, S. Bashir, S. \& Hussain, R. (2013) Foreign Students'motivation For Studying In Malaysia, International Journal of Asian Social Science, 3(3),PP.833-846. 


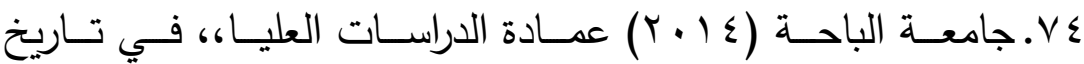
http://portal.bu.edu.sa/web/guest/1293

$$
\text { . } r \cdot 1 \leq / r / \Lambda
$$

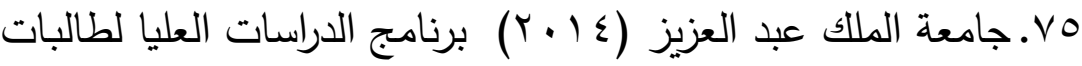

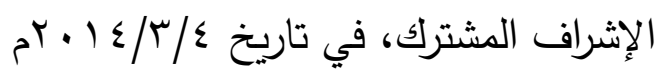

http://joint.kau.edu.

sa/Default.aspx?Site_ID=323\&Lng=AR

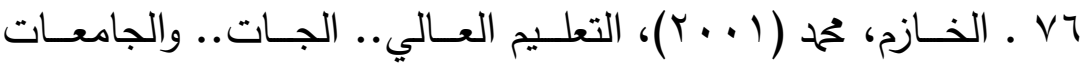

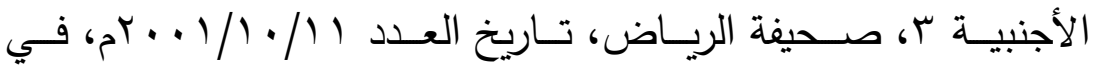

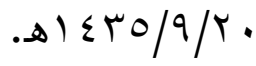

‘http://www.alriyadh.com/30957

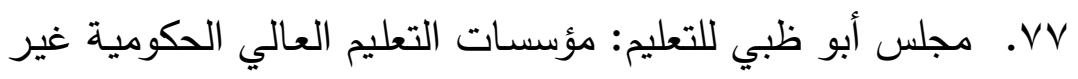

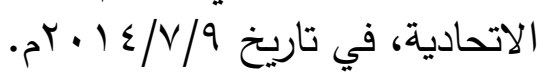

http://www.adec.ac.ae/ar/Education/HigherEducation/ Pages/My-HE-Options.Aspx

VA المجلس الأعلى للتعليم: قائُة جامعات المدينة التعليمية بقطر ، http://www.sec.gov.qa/Ar/SECInstitutes/HigherEd ucationInstitute/Offices/Documents/5Education_City_Universities.pdf

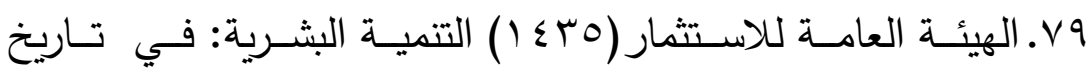
ه $15 \% 0 / 9 / 19$ ‘/http://www.sagia.gov.sa/ar/Key-sectors1/Education

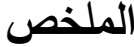

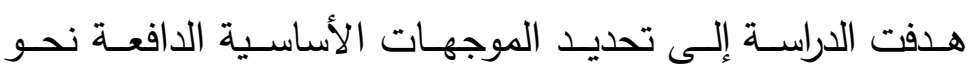

الترخيص لفروع جامعات عـابرة للحدود في المملكة العربيـة السـودية والكثف عن فروق ذات دلالة إحصائية بين متوسطات تقدير استجابات

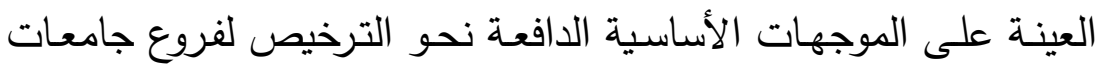
عابرة للحدود في المملكة العربية السعودية تعزى لمتغيرات الدراسة وهي: 
النوع، التخصص، الجنسية، الرتبـة الأكاديميـة. ولتحقيق هذه الأهداف

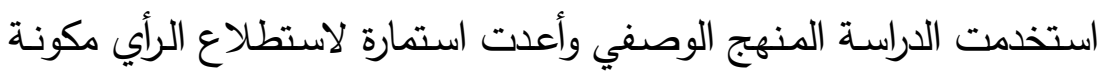
من (rr) فقرة شملت موجهات اجتماعية، وموجهات اقتصادية، وموجهات

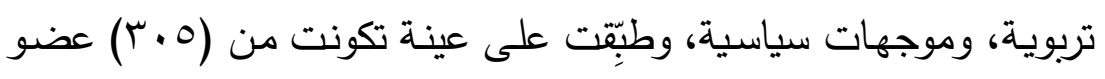

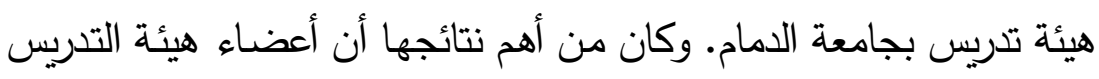

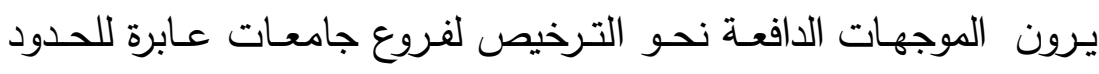

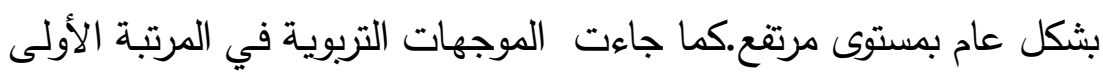
في الترتيب يليها الموجهات الاجتماعيـة ثم الموجهات السياسية، وأخيرا الموجهات الاقتصـادية. مـع عدم وجود فروق ذات دلالمة إحصـائية بـين متوسطات تقدير استجابات العينة على الموجهات الدافعة نحو الترخيص

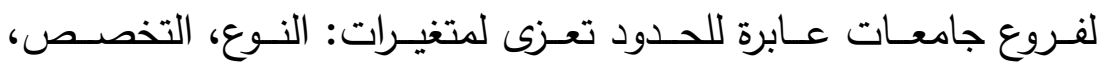
الجنسية، الرتبة الأكاديمية. وتم توضيح بعض الإيجابيات وسبل تدعيمها،

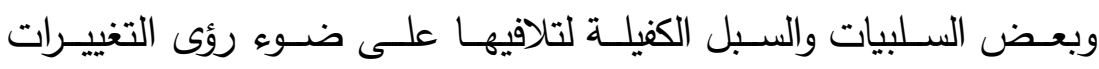

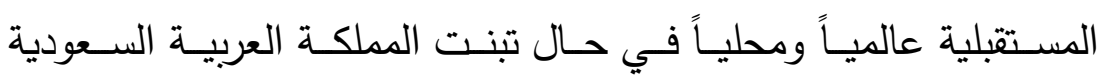
الترخيص لفروع جامعات عابرة للحدود.

الكلمات المفتاحية: فروع الجامعات، الجامعات الدولية، التعليم العالي عبر الحدود، تدويل.

\section{Abstract}

The study aims to identify the main guidelines for giving licenses to Branches of Cross-border Universities in the Kingdom of Saudi Arabia. It aims to reveal differences of statistical significance between the means estimation of sample response on the the main guidelines for giving licenses to Branches of Cross-border Universities in the Kingdom of Saudi Arabia that relate to the study variables. These 
variables are: Sex, specialty, nationality and academic status.

To achieve these objectives the study used the descriptive method and prepared a survey questionnaire consists of (32) paragraphs that include social, economic, educational and political guidelines. The questionnaire was applied to a sample consisted of (305) teaching staff at Dammam university. The study reached the following:

- Teaching staff see guidelines that drive toward license to some Branches of Cross-border Universities in Saudi Arabia, in a general high level.

- Educational guidelines come first followed by social and political ones. Economic guidelines come last.

- The lack of statistically significant differences between the means estimation of sample response on the the main guidelines for giving licenses to Branches of Cross-border Universities in the Kingdom of Saudi Arabia, that relates to the variables of sex, specialty, nationality and academic status.

It has been clarified some of positives and ways of supporting and some negatives and ways to avoid them in the light of the visions of future changes, globally and locally, in the case of saudi arabia has a dopted a license to Branches of Cross-border Universities.

Keywords: Branches of universities, International universities, cross-border higher education, internationalization. 